\title{
The influence of clients on the social identities within the audit profession
}

\author{
Studies on the Swedish audit arena
}

\section{Johanna Sylvander}

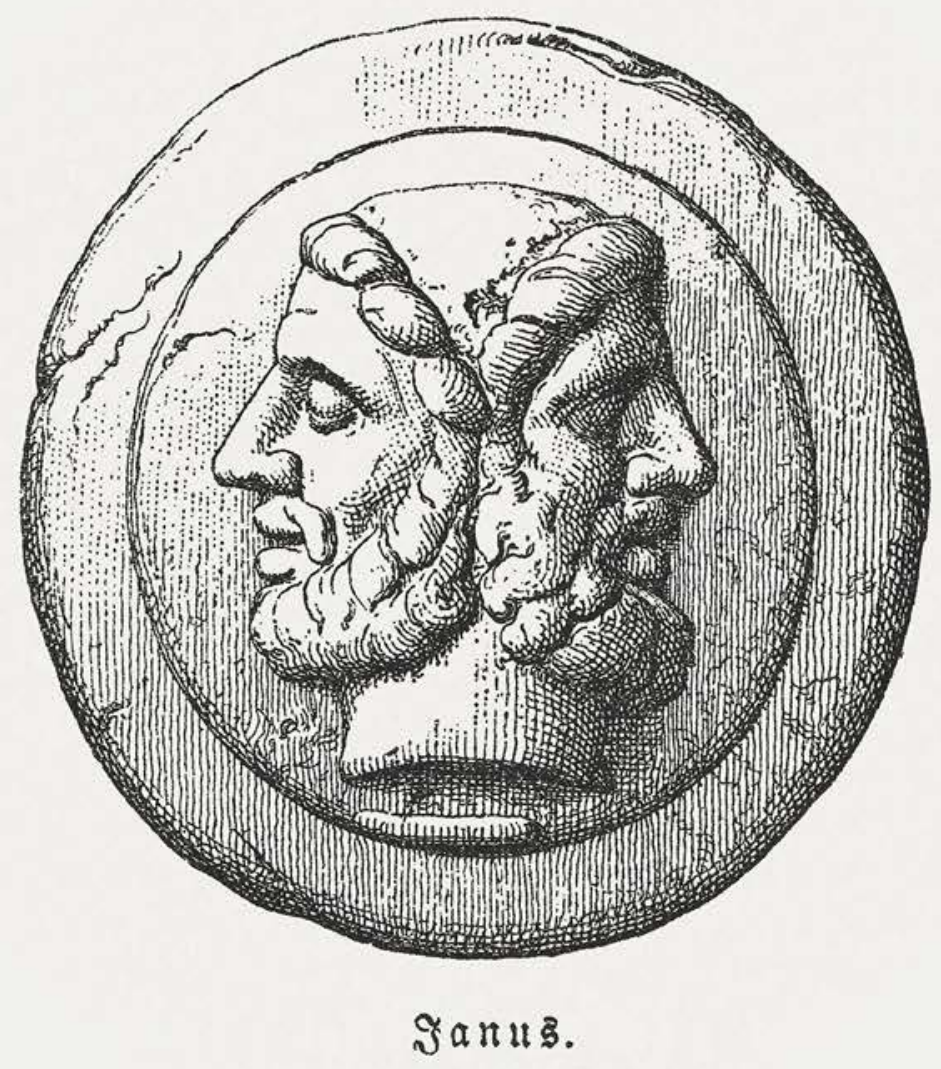


The influence of clients on the social identities

\title{
within the audit profession
}

Studies on the Swedish audit arena

\author{
Johanna Sylvander
}

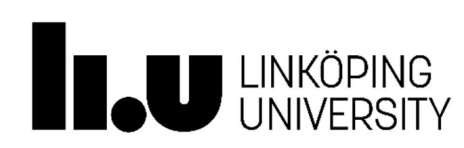

Linköping Studies in Arts and Sciences No. 784

Faculty of Arts and Sciences

Linköping 2020 
Linköping Studies in Arts and Sciences • No. 784

At the Faculty of Arts and Sciences at Linköping University, research and doctoral studies are carried out within broad problem areas. Research is organized in interdisciplinary research environments and doctoral studies mainly in graduate schools. Jointly, they publish the series Linköping Studies in Arts and Sciences. This thesis comes from the division of Business Administration at the Department of Management and Engineering.

Distributed by:

Department of Management and Engineering

Linköping University

SE-581 83 Linköping

Johanna Sylvander

The influence of clients on the social identities within the audit profession

Studies on the Swedish audit arena

Edition 1:1

ISBN 978-91-7929-886-9

ISSN 0282-9800

Cover: Janus - the Roman god of gates, doors, doorways, beginnings and endings (iStock/ZU_09)

CJohanna Sylvander

Department of Management and Engineering 2020

Printed by: LiU-Tryck, Linköping, 2020 


\section{Abstract}

The overall purpose of the thesis is to explore the meaning of professionalism and independence for the individuals within the audit arena. Professionalism is defined as the occupational values that guide auditors' professional behaviour, and how independence is understood is assumed to be influenced by the social groups the auditors identify with. The audit arena consists of several social actors, i.e. the audit profession, audit firms, and auditors, as well as external constituencies of the profession, i.e. accountors and accountees. The audit profession both serves the public interest by quality-ensuring the information provided by the accountors to the accountees as well as conducts business in a state-sanctioned monopoly-like market. Appearing independent and professional is therefore critical for the profession as independence and professionalism is the basis of society's trust in the profession and may particularly influence the profession's ability to recruit and retain staff.

The audit profession, audit firms, offices and audit teams are social groups which influence the values, attitudes, and behaviours of the auditors through the process of socialization into the profession and the audit firm. However, accountors (i.e. clients) and accountees (i.e. stakeholders such as investors) are also social actors, who may influence the values, attitudes, and behaviour of auditors, if auditors identify with these social actors. Exploring the social identities at 'play' within the audit arena enables us to more fully understand the values that guide professional work.

The thesis empirically investigates the social identity audit arena through potential, current, and former audit employees' perceptions of the audit arena, where the data is both qualitative (interviews) and quantitative (surveys) in nature. The empirical material provides both presocialized and post-socialized perspectives on the audit arena, where the bulk of the material stems from the pre-socialized perspective. The thesis suggests that there are two types of auditors, namely small client auditors and large client auditors, where the small client auditor group dominates the audit arena. The role of the small client auditor is described differently from the large (public) client auditor's role. The small client auditor is perceived as a teacher who helps the clients run their businesses better, and avoid problems with tax authorities et cetera, making it necessary for the auditor to have a good and close relationship with the client in order to fulfil her/his role. The large client auditor is described more as having the 'traditional' guardians of the market role. Hence, it seems as the small client auditor is guided by other values and has a different understanding of independence compared to the large client auditor. However, the large client auditor is also perceived as having a counselling teacher role, indicating that some professional values are shared by small client and large client auditors.

These different roles auditors are perceived to have, where independence and working for the public interest seem to mean different things, can influence how new audit employees perceive the profession. If employees expect to work as 'large client auditors', but instead experience work being guided by small client auditor values (or vice versa), it may influence the willingness to stay in the profession. These two roles are also a potential factor influencing the expectation gap, i.e. the gap between what society thinks the auditor does and what $\mathrm{s} /$ he does in practice. These two roles may therefore influence society's image of the auditor, and where the profession may have issues in appearing independent in the relationship with small clients.

Key words: audit profession, audit firms, auditor, professionalism, independence, social identity, clients 


\section{Sammanfattning}

Avhandlingens övergripande syfte är att utforska innebörden av professionalism och oberoende för individerna inom revisionsarenan. Professionalism definieras som de yrkesrelaterade värderingarna som styr hur man som professionell revisor bör agera och hur oberoende förstås antas påverkas av vilka sociala grupper revisorn identifierar sig med. Revisionsarenan består av flera sociala aktörer, nämligen revisionsprofessionen, revisionsbyråer, och revisorer, och även externa intressenter till professionen, nämligen redovisningsskyldiga och redovisningsberättigade. Revisionsprofessionen har ett viktigt samhällsuppdrag att kvalitetssäkra informationen som de redovisningsskyldiga tillhåller de redovisningsberättigade. Dock bedriver professionen samtidigt affärer på den monopolmarknad professionen har genom den lagstadgade revisionen. För professionen är det därmed av yttersta vikt att framstå som oberoende och professionell, då oberoende och professionalism är grunden för samhällets tillit till professionen. Innebörden av professionalism och oberoende inom revisionsarenan kan speciellt påverka professionens möjligheter att rekrytera och behålla personal.

Revisionsprofessionen, revisionsbyråerna, arbetskontoren och revisionsteamen är sociala grupper som påverkar revisorers värderingar, attityder och beteende genom socialiseringen in i professionen och revisionsbyrån. De redovisningsskyldiga (klienter) och de redovisningsberättigade (intressenter så som investerare) är andra sociala aktörer som kan påverka revisorers värderingar, attityder och beteende, om revisorerna identifierar sig med dessa sociala grupper. Genom att utforska vilka sociala identiteter som verkar inom revisionsarenan kan vi få större kunskap kring vilka värderingar som styr det professionella arbetet.

Avhandlingen undersöker potentiella, nuvarande och före detta revisionsmedarbetares uppfattningar om revisionsarenan, där empirin både är av kvalitativ (intervjuer) och kvantitativ (enkäter) natur. Det empiriska materialet ger både ett 'försocialiserat' och 'eftersocialiserat' perspektiv på revisionsarenan, där tyngden ligger på det försocialiserade perspektivet. Avhandlingen tyder på att det finns två typer av revisorer, nämligen 'småbolagsrevisorer' och 'storbolagsrevisorer', där 'småbolagsrevisorer' är den största gruppen. 'Småbolagsrevisorns' roll beskrivs annorlunda jämfört med hur 'storbolagsrevisorns' roll beskrivs. 'Småbolagsrevisorn' uppfattas som en lärare som hjälper klienterna att driva sina företag bättre, och undvika problem med Skatteverket med mera, vilket innebär att revisorn måste ha en god och nära relation med klienten för att kunna uppfylla sin roll. 'Storbolagsrevisorn' beskrivs mer som revisorsrollen traditionell beskrivs, d.v.s. som en 'marknadsväktare' och en oberoende granskare. Det verkar alltså som att 'småbolagsrevisorn' utgår ifrån andra professionella värderingar och har en annan förståelse av oberoende jämfört med 'storbolagsrevisorn'. Dock uppfattas 'storbolagsrevisorn' även ha en rådgivande lärarroll, vilket indikerar att 'småbolagsrevisorer' och 'storbolagsrevisorer' delar vissa professionella värderingar.

Dessa olika roller som revisorer upplevs ha, där oberoende och arbete för det allmännas intresse verkar betyda olika saker, kan påverka hur nya anställda upplever revision som yrke. Om anställda förväntar sig att arbeta som en 'storbolagsrevisor' men istället får uppleva yrket som en 'småbolagsrevisor' (eller tvärtom) så kan det påverka viljan att vara kvar i yrket. Dessa två roller är även en potentiell aspekt som påverkar förväntansgapet, dvs skillnaden mellan vad samhället tror att revisorn gör och vad hen faktiskt gör. Dessa två roller kan alltså påverka samhällets bild av revisorn, där revisionsprofessionen kan ha svårt att hävda sig vara oberoende gentemot dessa mindre klienter.

Nyckelord: revisionsprofessionen, revisionsbyråer, revisorer, professionalism, oberoende, social identitet, klienter 
To whom it may concern 


\section{Acknowledgements}

It has been a privilege, and an experience I am forever grateful for, being a doctoral student. I am forever grateful for the two people that opened my eyes for Academia, as I have finally found the place in the world in which I belong. Pernilla Broberg, and Timur Uman, thank you!

I have had the privilege of having Torbjörn Tagesson and Pernilla Broberg as my supervisors. I cannot thank you enough for letting me do things my way and allowing me to do things 'independently'. You have always been there when I needed it, and you have forced me to stay on track when I have 'strayed away', i.e. when I tried to do way too much and incorporate every theory in the world and every perspective in one single project. You, as a pair, work great together as you complement each other and for me personally, your combined knowledge, experience, and personalities, have been just what I needed. Tack!

My socialization into academia started during my studies in Kristianstad University. I met many engaged teachers and other university staff during these years, some of whom I became colleagues with during my year as a lecturer before my PhD studies. I want to particularly acknowledge a few of these people besides Timur Uman and Pernilla Broberg, as they helped me develop skills relevant for academic life in various ways (I have tried to keep this in 'order of appearance'). From the time when I was a student: Linus Sjödahl, thanks for being an inspirational teacher in accounting. Markus Sandblom, your course in commercial law has been invaluable. Daniela Argento, you are an inspiring lecturer and you are one of my role models when it comes to teaching. Nils-Gunnar Rudenstam, I appreciate all the knowledge you have shared with me (both as a student and co-worker) and you were a valuable guide into Charles Perrow's world. From my time as a lecturer: Anne-Marie Jontoft and Lisa Källström, thank you for providing me with help with and guidance on matters of teaching. Anna-Karin Valdén Sjödahl, Linda Johansson and Zahida Sarwary, you have not only been socially valuable actors in the workplace, but you have also taught me the importance of having the 'right' attitude. In particular, I would like to thank Elin Smith and Sven-Olof Yrjö Collin and the rest of 'Engagerade-klubben' (you know who you are), you all have helped me develop my own academic ethical values by providing me with different perspectives on things. Collin, you also deserve a particular 'shout-out' for 'fuelling' my interest in ethics.

Starting my $\mathrm{PhD}$ studies in Linköping meant a socialization into a new organization, and I want to thank all my colleagues at FEK for making the transition into a new role, and a new context easy. I want to particularly thank Lars Witell and Hugo Guyader, who were the first people outside of our accounting/auditing group whom I socialized with during my first doctoral course. Over the years, there are others at the department whom I have had closer interactions/interesting discussions with and who have made working more enjoyable and/or have provided me with constructive criticism. Linus Axén, Josefine Rasmussen, Svjetlana Pantic-Dragisic, Aliaksei Kazlou and Hugo - you have been the core of our social group 'the $\mathrm{PhD}$ students' during my time as a PhD. Thank you for making me a part of your group! ÅsaKarin Engstrand - thank you for inviting me to teach in your Business Ethics course! It has been a great experience and working with you is a pleasure. Karin Bredin, Mikael Ottosson, Lars Witell and Andrea Fried- thanks for constructive criticism on the yearly PhD workshops (I sincerely hope I did not forget anyone!). An additional thank you to Karin for the valuable comments on the 'pre-print' version of this thesis. Also, a special thanks to the wonderful administrator who has made my life easier: Maria (Mia) Sjöqvist!

Conferences and courses during these years as a doctoral student have been valuable in my socialization into the larger Swedish academic profession, and I appreciate getting the opportunity to meet scholars from various disciplines and from various universities. Thanks for 
all interesting discussion (no one mentioned, no one forgotten)! However, I would like to particularly highlight the events which and people who have been valuable in the socialization into the Swedish accounting academia. In particular, the Biannual Swedish Accounting conference has been a valuable opportunity to get to know all Swedish accounting and auditing colleagues. Linköping had the honour of hosting the conference in the fall of 2019. Pernilla Broberg did most of the grunt work in organizing the conference, but this opportunity allowed me to get insight into what it means to host a conference. I have to say - I will appreciate the conferences even more in the future! One doctoral course has been of particular value to me, both in my research and my teaching; the doctoral course on empirical research in financial accounting held at Gothenburg University in 2016. Jan Marton, Emmeli Runesson, and Niuosha Samani, and all that attended the course- thank you for a valuable experience!

My socialization into academia has also involved conferences and course abroad. The EARNet organization, with its biannual $\mathrm{PhD}$ workshop and audit conference and EDEN doctoral seminar on audit research has been particularly valuable to me as it has introduced me to audit research colleagues from all over the world. A special thanks to all the PhDs and researchers I have met through these conferences and courses and all of you that have given me feedback on my work (no one mentioned, no one forgotten)! However, I would like to particularly thank Stuart Turley for commenting on a previous version of appended paper II at the EARNet PhD workshop in Parma, Italy 2019. Also, a special thanks to Chris Humphrey for the inspiring discussion at the $10^{\text {th }}$ EARNet symposium in Parma. It really helped me in clarifying my thoughts, and the points and arguments in the thesis.

Lastly, there are some people I would like to send special thanks to for different reasons. First, Johan Alvehus - thanks for the invaluable input at the final seminar. As you see, this dissertation is a completely different text than what you read back then, and I own a lot of it to you (any remaining flaws am I solely accountable for)! Secondly, Nellie Gertsson - thank you for letting me in on your project and being my companion on both the EARNet conference and the EDEN course in 2017. Writing papers and discussing with you, and the struggles we had with handling reviewer comments (with the support of Pernilla) has taught me a lot and I truly appreciate our time together. Thirdly, Margret Sykes, thank you for proofreading the thesis - I am thankful for having such an English-proficient neighbour! Fourthly, Linus Axén - thank you for being my 'partner in crime' in our accounting/auditing group. You have always been someone I can discuss small and large matters with. It has been a pleasure working with you, and I look forward to work with you in the future! Fifthly, Ulla and Nils Sylvander, my parents-in-law, thank you for your support! Finally, Anders Sylvander, thank you for being my husband and my best friend in the whole world! Thank you for putting up with me working $380 \mathrm{~km}$ from home, which means that we do not see each other as much as we used to. Du är mitt lilla hjärtegull.

Askeröd, February 2020

Johanna Sylvander 


\section{Appended papers}

Paper I Sylvander, J., (2020). Exploring potential (mis)matches between Millennials' wants and audit employment expectations and audit firm reality, (working paper).

Paper II Sylvander, J. (2020). The audit profession as an 'divided' educational institution: perceptions of auditing among potential employees, (working paper).

Paper III Gertsson, N., Broberg, P., Friberg, J., and Sylvander, J. (2018). Exploring Motivational drivers of Audit Employees - A Study Focusing on Generation Y, Journal of Accounting and Finance, 18(2), 89-105.

Paper IV Gertsson, N., Sylvander, J., Broberg, P., and Friberg, J. (2017). Exploring audit assistants' decision to leave the audit profession, Managerial Auditing Journal, 32(9), 879-898.

Published articles reprinted with permission from North American Business Press (Journal of Accounting and Finance) and Emerald Publishing (Managerial Auditing Journal) 


\section{Table of Contents}

Part I: Holistic analysis study ...................................................................................................... 1

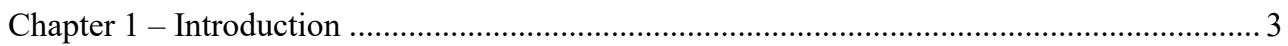

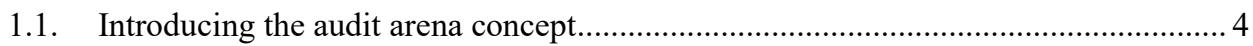

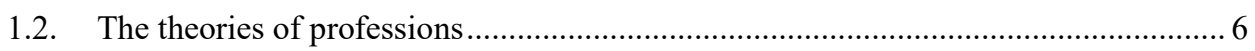

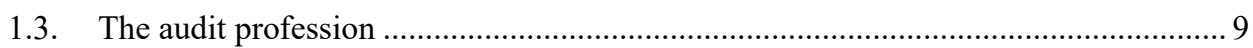

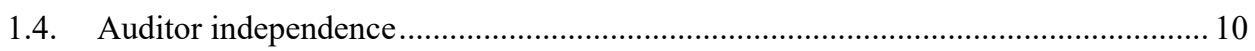

1.5. The purpose and empirical basis for the thesis ....................................................... 12

1.5.1. The research process, design and method ......................................................... 18

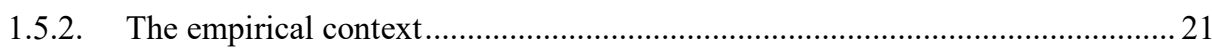

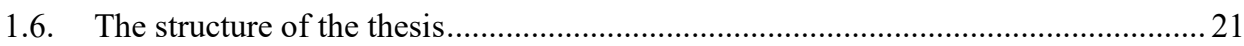

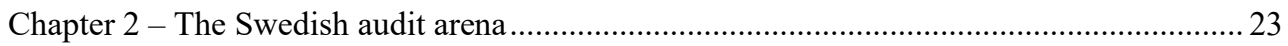

2.1. How the Swedish audit arena came to be and where it is now................................. 24

2.2. Current larger changes within the Swedish audit arena ............................................ 28

2.3. Differences between the Swedish and Anglo-Saxon audit arena ................................30

Chapter 3 - The audit arena from a social identity perspective ……………………………..... 35

3.1. An introductory note on the social identity perspective ............................................ 36

3.2. Social identities in professional and organizational contexts .................................... 38

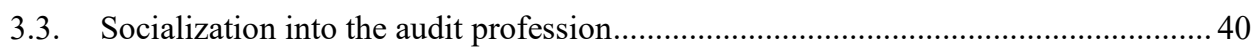

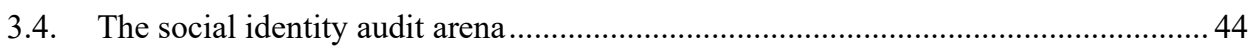

Chapter 4 - Pre-socialized narratives of the audit arena............................................................. 47

4.1. Narratives of (provisional) selves entering the audit arena ...................................... 48

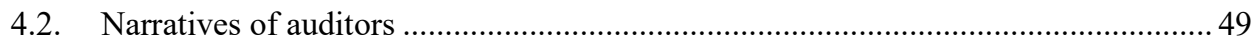

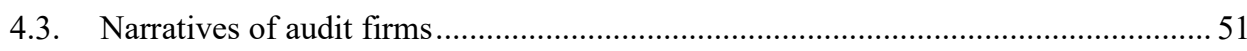

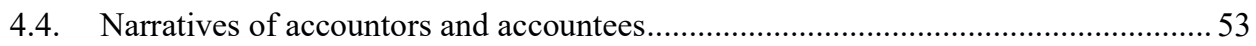

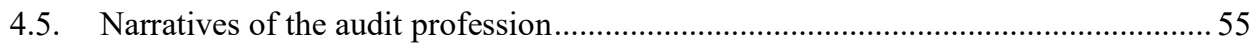

Chapter 5 - Post-socialized narratives of the audit arena .......................................................57 
5.1. Narratives told by current staff of auditors, audit firms and the audit profession ..... 58

5.2. Career progression and changes in narratives 61

5.3. Narratives told by former staff of auditors, audit firms and the audit profession ..... 62

Chapter 6 - The narrative of the social identity audit arena ...... 65

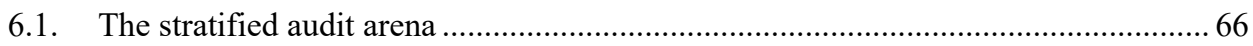

6.2. Different perspective on professionalism and independence ................................ 70

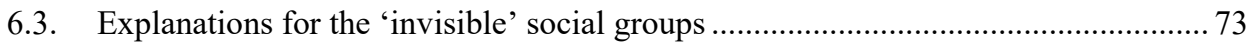

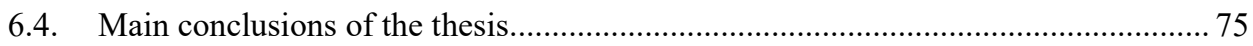

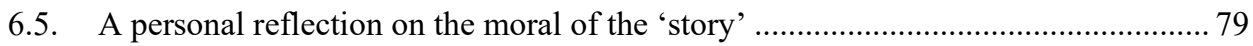

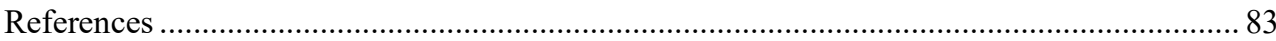

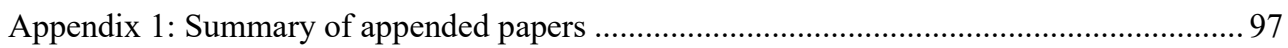

Paper I: Exploring potential (mis)matches between Millennials' wants and audit employment

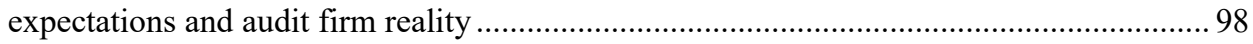

Paper II: The audit profession as an 'divided' educational institution: perceptions of auditing

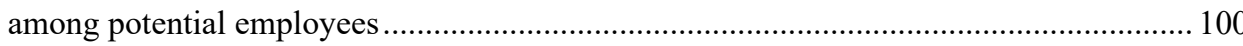

Paper III: Exploring motivational drivers of audit employees - A study focusing on

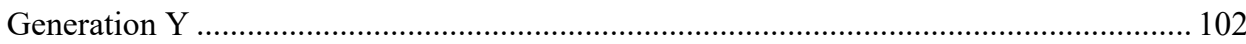

Paper IV: Exploring audit assistants' decision to leave the audit profession..................... 103

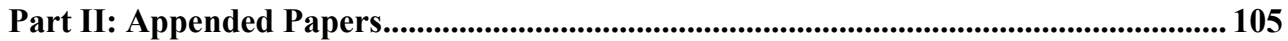

\section{Figures and tables}

Figure 1: The audit arena (replication and translation and minor adaptation of figure 9.3 in Öhman, 2007 with permission from the author; also see Öhman et al., 2006) ......................... 5

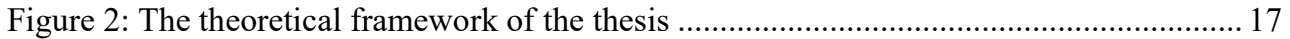

Figure 3: Social identities within the professional and organizational audit context.............. 41 Figure 4: The social identity audit arena (a development of Öhman (2007)'s audit arena) .... 45 Figure 5: The narrated social identity arena - an alternative 'picture' of the audit profession 69 Figure 6: The thesis contributions to the substantive and conceptual theory............................ 76

Table 1: The purposes of the thesis, the holistic analysis, and the appended papers ............... 14

Table 2: Overview of data collection, respondents, design, and method of analysis............... 19

Table 3: Turnover and number of employees in the Big Swedish audit firms.......................... 27 
Part I: Holistic analysis study 


\section{Chapter 1 - Introduction}

This chapter begins with an introduction to the audit arena; a concept which conceptualizes the relationship between the audit profession, audit firms, and auditors, and the external constituencies of the profession, the accountors and the accountees (e.g. Öhman, 2007). The audit profession is an abstract entity, which manifest itself through professional bodies, audit firms, and auditors (Brouard et al., 2017). The profession both serves the public interest by providing quality-ensured information from accountors to accountees as well as conducts business in a monopoly-like market (Öhman, 2007). Appearing independent and professional is therefore critical for the profession as independence and professionalism is the basis of society's trust in the profession (cf. Brien, 1998; Gou, 2018). This chapter argues that a social identity perspective can enhance our understanding of the social threats to professional independence and problematizes the current view of the audit arena by using the theory of professions, and the literature on the audit profession and auditor independence. This leads to the overall purpose of the thesis, which is to explore the meaning of professionalism and independence for the individuals within the audit arena. Professionalism is defined as the occupational and normative values that underpin the professional narrative (cf. Ackroyd, 2016; Evetts, 2011) and independence as conformity and deviance in relation to social identities (Warren \& Alzola, 2009). The chapter continues by presenting the research process and method as well as the papers and empirical material used in this exploration and ends with a presentation of the structure of the remainder of the thesis. 


\subsection{Introducing the audit arena concept}

Öhman (2007) conceptualizes the audit arena as the relationships between three parties; the auditor, the accountee and the accountor, as well as the relationship between the audit profession and society. The accountors ${ }^{1}$ are the "management representatives in charge of operations with stewardship obligations and who are obliged to provide true and fair information" to the accountees, i.e., "investors and other stakeholders entitled to information for their decision-making process" (Öhman et al., 2006, p. 92; see (a) in figure 1). The auditor serves as an independent party in the relationship between the accountor and the accountee and ensures the quality of the information provided by the accountor to the accountee (Öhman, 2007; see (b) and (c) in figure 1). The auditor also provides additional information to the accountees through the audit reports (Öhman, 2007; also see Power, 1997; see (d) in figure 1). However, the auditor is not the only social actor within the profession as the individual auditors are employed by audit firms. The audit firms as well as the audit profession are social entities which influence the individual auditors' behaviour in the contact with the accountors and the accountees (see (e) and (f) in figure 1). There are two parallel agendas at play within the audit arena; "[o]n the one hand, the audit profession has been given an important societal mission by the government [...], on the other hand, the audit firms do business for their own account within the audit profession's monopoly-like position" (Öhman, 2007, p. 125-126, my translation).

\footnotetext{
${ }^{1}$ Within the audit literature, accountors are more commonly referred to as clients. In professions in general, the term client refers to the person or entity that engages the professional advice or services of another (Client, 2019; cf. von Nordenflycht, 2010). However, within the audit profession, clients are more commonly referred to as customers. In this thesis, the terms accountor and client are used interchangeably, i.e. both terms denote the theoretical concept 'accountor' as defined here. The terms do not signal different things, and the choice to use one term over another only depends on which term best fits the text from a readability and clarity point of view.
} 


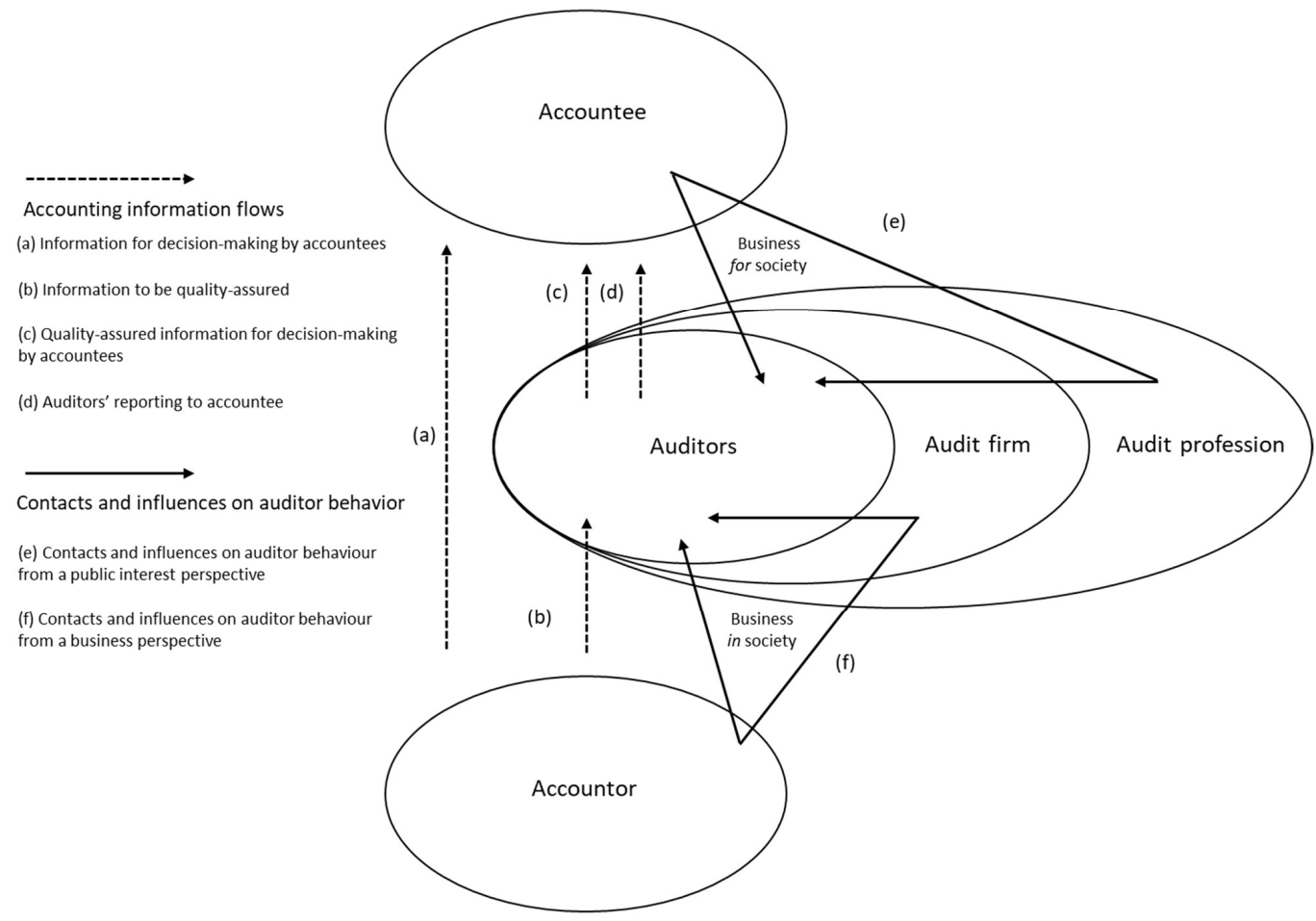

Figure 1: The audit arena (replication and translation and minor adaptation of figure 9.3 in Öhman, 2007 with permission from the author; also see Öhman et al., 2006)

The audit profession, which is embedded within the accounting profession, is an abstract entity as there is no one organization that embodies the profession (cf. Sellers \& Fogarty, 2010). The audit profession is an institution in society (cf. Power, 1997), manifested and represented by professional bodies, such as the global body IFAC and local national professional organizations such as the Swedish professional association FAR, who constitutes the members in IFAC (IFAC, n.d.), as well as audit firms and individual auditors (Brouard et al., 2017). The standard setting bodies are arguably important actors due their influence on the regulation processes and the legitimacy of the rules and practices produced (Cooper \& Robson, 2006), where the Big 4 accounting firms ${ }^{2}$ are deemed to have particular influence on these processes through their dominant presence within the standard setting bodies (e.g. Humphrey \& Loft, 2006). The Big 4 firms are also important actors, since it is here "where accounting practices emerge, become standardized and regulated, where accounting rules and standards are translated into practice,

\footnotetext{
${ }^{2}$ The Big 4 firms are Deloitte, EY, KPMG and PwC.
} 
and where professional identities are mediated, formed and transformed." (Cooper \& Robson, 2006 , p. 416). Thus, the audit firms arguably play a particularly important role in the formation of the auditor identity and have particular influence on auditor behaviour (Anderson-Gough et al., 1998; see (e) and (f) in figure 1).

The most tangible relationships for auditors are those with their closest co-workers and the accountors they meet in their day-to-day work. Auditors interact with co-workers from different hierarchal levels and other professionals within the firm, who are consulted as experts and accountors differ in terms of size, industries, and ownership (Broberg, 2013). It is in these contacts that the individual learns what it means to be an auditor (Anderson-Gough et al., 1998) and it is in these contacts that other external constituencies physically encounter the profession and influence auditor behaviour (see (e) and (f) in figure 1).

The function of the audit is fundamentally based on auditor independence, i.e. being independent of the accountors and the information that they provide, in order to provide an objective assurance (e.g. Broberg, 2013; Öhman, 2007). The audit profession, the audit firms, and auditors must portray independence to the public, i.e. the accountees, (cf. Abbott, 1988), for the audit to be meaningful and serve its function (Jeppesen, 1998; see (e) in figure 1). However, as the audit profession does not only do business for society, i.e. providing a societal service, but also does business in society, i.e. audit firms competing with each other over accountors (Öhman, 2007; see (f) in figure 1), the profession's independence has been criticized as its own financial interests seems to trump the public interest motives (cf. Hanlon, 1996). It has therefore been questioned whether the audit profession is a profession or not. But what are professions? This is discussed in the next section.

\subsection{The theories of professions}

Professions are referred to as powerful institutions in society (cf. Muzio et al., 2013) and are claimed to have "assumed leading roles in the creation and tending of institutions." (Scott, 2008, p. 219, cited in Muzio et al., 2013). Talcott Parsons is claimed to be the 'founder' of the theories of professions as he and his followers "initiated the paradigm and tradition of this object of research" (Brante, 1988, p. 120). Parsons as well as Carr-Saunders \& Wilson (1933) saw the functional roles of professions as important as they "are stabilizing elements in society" that "engender modes of life, habits of thought, and standards of judgments which render them

centres of resistance to crude forces which threaten stable and peaceful evolution" (p. 497; also see e.g. Muzio et al., 2013). According to Muzio et al. (2013), these early authors saw 
“professions' moral fibre stem[ming] from their ability to place fairness, knowledge, and altruism at the centre of society" (p. 702). This functionalist view of professions led to an interest in defining what traits professions have that distinguish them from other occupations; however, consensus was hard to reach (e.g. Evetts, 2011). The common key traits mentioned are: independent work for the public good, a state-sanctioned or monopoly domain, an esoteric knowledge-base (e.g. Anderson-Gough et al., 1998), "codes of conduct to ensure professional integrity", "members having a feeling of identity, sharing common values" and "a common language [...] which can only be partially understood by outsiders" (Brante, 1988, p. 122). Professions have also been claimed to be characterized by "work that requires formally organized, theoretical or abstract knowledge for its adequate performance" and "training [...] heavily weighted by book learning" (Friedson, 1989, p. 425).

As no consensus on the traits of professions emerged, research shifted its focus to the process of professionalization, i.e. how professions develop (cf. Abbott, 1988). According to Wilensky (1964), professions evolve by (1) there being a need for practitioners, (2) by pressures from practitioners or clients leading to the creation of training schools founded within or in collaboration with universities, (3) professional associations forming by those who pushed for training schools and those who first attended the training, which leads to paraprofessionals being created to perform the 'dirty work' of the professionals, internal competition emerging between those who have undergone training and those who learned by doing and external competition with neighbouring professions. (4) The profession then lobbies for a legally protected jurisdiction, and (5) formalizes rules to weed out the incompetent from the competent, minimize internal competition and protect the public service ideal, i.e. formal codes of ethics are established. Other researchers have told different narratives in terms of the order of the different events, but the main 'story' is that there are "clear sequences of professionalization" of the American professions (Abbott, 1988, p. 11). However, the narratives on the English professions indicated that professional associations form for different reasons, not directly related to an active pursuit of professional status, such as the need to coordinate workers, and by providing technical development. Put differently, the clear sequential structure of professionalization seems to be created by the narrative rather than by reality (Abbott, 1988). Anglo-Saxon research focused on professions that developed through market mechanisms, whereas European professions" "expertise was never formalized independent of the state" (Abbott, 1988, p. 6). Therefore, "[t]raditional Anglo-Saxon research has put strong emphasis on self-regulation, autonomy and self-control of professional groups [...] and has generally 
considered the role of the state as being limited to legally supporting the monopoly of the members of the profession." (De Beelde, 2002, p. 449).

The field transitioned into symbolic interactionism in the 1980s, which focuses on micro-level actions between individuals and how social identities are created in every-day situations and how social identities affect individual behaviour (cf. Anderson-Gough et al., 1998). Abbott (1988) extended the interactionist framework as he demonstrated "how professionalism is negotiated on a day-to-day basis by showing how the professions collectively determine their existence through negotiation with society at various levels" (Anderson-Gough et al., 1998, p. 20). Abbott (1988) introduced the concept of interprofessional competition as the key to understanding both the control of knowledge and why professions emerge or fail to emerge, where the level and the strength of competition in combination with environmental aspects hinders or enables the control of knowledge and rise or fall of professional organizations. Abbott (1988) also discussed the internal heterogeneity of professions. Professions are internally stratified, meaning that individuals are ranked based on status, where the status reflects the degree to which the individual is involved in the organization of the professional knowledge. Those lowest in rank are those that perform the fundamental task, which is the basis for the public jurisdiction and its legitimacy, whereas high-status professionals are those that withdraw into themselves and away from the professional task. Client differentiation can reinforce the intraprofessional status differences, as high-status professionals generally serve high-status clients. Also, high-status professionals tend to work in high-status workplaces, meaning that high-status professionals rarely work with low-status professionals (Abbott, 1988).

Before the transition into symbolic interactionism, the professionalization literature adopted the concept of power, which "unmasked earlier work as ideological. The unmasking reached its final form in Magali Larson's The Rise of Professionalism" (Abbott, 1988, p. 5). Larson introduced the concept of professional projects, which "emphasize the agency of professions in achieving market power and social standing" (Muzio et al., 2013, p. 704). The professional project is "a concern with establishing high social status for individual professionals independent of their organizational affiliation" (Schudson, 1980, p. 216), but this status "is a mirage" as "professions fail to translate their status into power and autonomy" (Schudson, 1980, p. 219). 
Professionalism has also been viewed as an occupational or normative value and later as "professional narratives" (Ackroyd, 2016, p. 19) or "a discourse of organizational change and control" (Evetts, 2011, p. 11). The professionalism discourse has historically been used by professions "in constructing its occupational identity, promoting its image with clients and customers, and bargaining with states to secure and maintain its (sometime self) regulatory responsibilities" (Evetts, 2011, p. 11). It is this view of professionalism that this thesis adopts, when discussing the audit profession in the next section.

\subsection{The audit profession}

The accounting profession, in which the audit profession is embedded, emerged from the "new commercial and industrial heart of society" whereas other professions did not (Abbott, 1988, p. 3). This may be why the audit profession's status has from time to time been questioned as it does not seem to 'fit' the fundamental traits of professions (cf. Zeff, 1987). For example, whether the audit profession possesses a unique knowledge base has been questioned (cf. Fogarty, 1992; Guo, 2018). Audit firms, like other knowledge-intensive firms, arguably use knowledge as a legitimizing and identity construction tool rather than as a functional resource that is directly applied in work (Alvesson, 2001). However, the main critique revolves around whether the audit profession serves the public interest or its own financial interests (cf. Hanlon, 1996). Auditors have been claimed to be the guardians of the capital markets (cf. Humphrey \& Moizer, 1990) but the audit firms are governed and structured as profit-maximizing entities (cf. e.g. Picard, 2016; Stenger et al., 2017). However, the profession itself considers it a profession as do researchers (see e.g. Broberg, 2013; Cooper \& Robson, 2006; Power, 1997; Öhman, 2007), and "[t]o say a profession exists is to make it one" (Abbott, 1988, p. 81).

Contemporary research portrays the audit profession as a profession that combines two logics; i.e. professional logics and commercial business logics (see e.g. Bévort, 2012; Broberg, 2013, Lokatt, 2018; Sweeney \& McGarry, 2011), where the professional logic is based on the idea that "protected professionals treat cases" and the commercial logic is based on the idea that "well-run organizations deliver products for customers" (Lokatt, 2018, p. 102). Professional firms are coordinated through skills and norms, base authority on expertise and service ethic and value quality and humanity, whereas commercial firms coordinate through hierarchy and market, base authority on results and accountability and value efficiency and profitability (Lokatt, 2018). The audit profession is thus often referred to as a 'hybrid' profession as professionalism is based on both professional and commercial logics, where auditors are guided 
by a single, combined logic in their day-to-day work (cf. Alvehus, 2018; Broberg et al., 2018; Lokatt, 2018; Malsch \& Gendron, 2013).

Auditors are depicted as individuals who possess a professional as well as an organizational identity (see e.g. Bamber \& Iyer, 2002; Broberg et al., 2018). Authors have argued for tensions or conflicts between the identities, and tensions or conflicts are arguably stronger if the identities are formed on professional versus commercial logics (cf. Bévort \& Suddaby, 2016; Suddaby et al., 2009). However, this conflict does not seem to be prevalent for auditors (Suddaby et al., 2009; cf. Broberg et al., 2018), even if some tensions between the logics have been found for auditors that audit public interest clients (Carrington et al., 2013). Grey (1998) suggests that the identities are not separate concepts in practice, as professional identity is influenced by the audit firms' 'prototypical' ideas of professionalism, an idea supported by Norris \& Niebuhr (1983), Suddaby et al. (2009) and Carrington et al. (2013).

Auditors are also depicted as similar regardless of the employing firm, despite little interaction between professional members from different firms (Anderson-Gough et al., 1998). Hence, the literature paints a relatively coherent picture, despite the variation of firms and locations studied $^{3}$. Auditors are individuals who act in the name of the client (Anderson-Gough et al., 2000), fight for their own survival and reputation within the firm (Stenger et al., 2017; cf. Öhman et al., 2006), and work efficiently (Svanberg \& Öhman, 2013) in order to be seen as a profitable investment by the partners (Stenger et al., 2017). However, there is still a prevailing discourse of professional independence (Anderson-Gough et al., 1998), and the function of the audit is rooted in auditor independence (Öhman et al., 2006; cf. Ijiri, 1983; Guo, 2018). However, for individual auditors, the idea of independence might be too abstract "for defining who they are in a field that has become increasingly permeated with commercialism" (Guo, 2018, p 23). But what is auditor independence? The literature on independence is discussed in the next section.

\subsection{Auditor independence}

Independence is arguably of particular importance to the audit profession as "independence is probably the very selling point of audit services, which supposedly provide investors and other financial information users a third-party, independent opinion on financial reports." (Guo, 2018,

\footnotetext{
${ }^{3}$ However, this might be a variation in appearance and not in fact, since firms are anonymized in published papers. Also, these studies mainly represent the Big 4 audit firms.
} 
p. 23). Kouakou et al. (2013) states that "auditor independence does not have a single, fixed and universally recognized meaning" as "the field is characterized by rivalry between competing meanings of independence" (p.1282) and in practice, the meaning of independence is constantly (re)negotiated (Guénin-Paracini et al., 2015). Power (1997) distinguishes between operational and organizational independence. Operational independence relates to the audit process, and the auditor's capability to be independent, as auditing is dependent on information supplied by the accountor and audit knowledge must be independent of the accountor (Jeppesen, 1998; Power, 1997). In other words, auditor independence can be understood as the auditor conducting the audit without influence from others, having access to the information needed regarding everything that is examined, and based on this, expressing an opinion or recommendation not biased by others (Jeppesen, 1998). Organizational independence relates to not being guided by others or one's own personal interests (Warren \& Alzola, 2009), and "the problem of organizational independence is to design an incentive structure" in order to ensure independence (Power, 1997, p. 132) ${ }^{4}$. Viewing independence as organizational independence makes it harder to define what independence is as it depends on which and how many interests are involved or considered (Jeppesen, 1998).

Officially, the profession considers independence to be "linked to the principles of objectivity and integrity" and comprises independence in mind and independence in appearance (IESBA, 2018, p. 29). Independence in mind (or fact) is "the state of mind that permits the expression of a conclusion without being affected by influences that compromise professional judgment, thereby allowing an individual to act with integrity, and exercise objectivity and professional skepticism." (IESBA, 2018, p. 29). Independence in appearance is "the avoidance of facts and circumstances that are so significant that a reasonable and informed third party would be likely to conclude that a firm's, or an audit team member's, integrity, objectivity or professional skepticism has been compromised." (IESBA, 2018, p. 29). It has been claimed that it does not matter if the audit profession, the audit firms, and the auditors are independent in fact, if the accountees do not see these actors as independent in appearance. Independence in appearance

\footnotetext{
4 Organizational independence has also been defined as "auditors' willingness to act in accordance with professional standards and to report errors found during the audit", and operational independence as "auditors' capability to work diligently and effectively in order to detect material anomalies" (Guénin-Paracini et al., 2015, p. 201). However, willingness implies a conscious act and own or others' interests can influence actions both consciously and unconsciously (cf. Baumeister, 2016).
} 
is therefore critical in the relationships between the actors within the audit arena (Jeppesen, 1998), and "[t]ypically auditor independence is conceptualized as a conflict of interests which arises when auditors have competing professional or personal interests" (Warren \& Alzola, 2009, p. 41).

Auditor independence has been argued not only to be a technical concept, but also a cultural and cognitive concept (Hudaib \& Haniffa, 2009; cf. Kouakou et al., 2013). Seeing auditor independence as a cultural and cognitive concept allows us to view auditor independence differently. Social identities are arguably important in professional and organizational contexts, as "social identity is the cognitive mechanism which makes group behaviour possible" (Turner, 1982, p.21, cited in Ashforth \& Mael, 1989). Auditor independence can thus be conceptualized as "a matter of conformity and deviance in relation to specific group identities" making us "able to fully consider the social influences that threaten independence" which "allows for new theoretical development" (Warren \& Alzola, 2009, p. 42). In other words, independence can be conceptualized as conflicts of salient social identities rather than as conflicts of interests (Warren \& Alzola, 2009). The profession and the employing audit firm are only two social categories auditors can identify with, whereas there are a multitude of social categories within the audit arena which individual auditors can possibly identify with (cf. Ashforth \& Johnson, 2001). Exploring other possible social categories within the audit arena could provide new insights and an alternative understanding of auditor identities and independence (cf. Broberg et al., 2018). This leads to the purpose of the thesis, which is presented in the next section as well as the empirical material used when exploring the audit arena.

\subsection{The purpose and empirical basis for the thesis}

The overall purpose of the thesis is to explore the meaning of professionalism and independence for the individuals within the audit arena. Professionalism is defined as the occupational and normative values that constitute the professional narrative (cf. Ackroyd, 2016; Evetts, 2011), and independence as conformity and deviance in relation to social identities, i.e. conflicts and alignments between salient social identities, as suggested by Warren \& Alzola (2009). As I take a social identity perspective on independence, the purpose of the holistic analysis (chapters 1 through 6) is to explore the social identities in play within the audit arena, which has not received much focus. Research rather assumes and categorises the relevant social identities within the arena as those of the profession, the employing audit firm and clients (cf. AndersonGough et al., 1998; Anderson-Gough et al., 2000; Bamber \& Iyer, 2002; Bamber \& Iyer, 2007: 
Broberg et al., 2018), whereas there are other possible relevant social identities in play (cf. Ashforth \& Johnson, 2001; Broberg et al., 2018).

The thesis consists of both qualitative and quantitative studies on the audit arena (see table 1). Each individual paper provides different perspectives on the audit arena, as they take different theoretical perspectives and provide different empirical contributions ${ }^{5}$. Appended paper I utilizes theories and studies related to human resource management and employer branding to explore Millennial accounting students' professional wants and needs and how they perceive the audit firms' employment offers. Paper I also discuss potential (mis)matches between Millennials' wants and audit firm expectations and audit firm reality. Appended paper II utilizes theories and studies related to the strategic management of professional firm reputation and identity to explore how potential employees perceive the audit profession. In this paper, perceptions are assumed to be influenced by auditors', audit firms' and the audit profession's strategic communication and the potential conflicts and alignments between the different actors' messages. Appended paper III utilizes theory and studies related to motivation and explores the motivational drivers of audit employees, whereas appended paper IV utilizes theory and studies related to job satisfaction and explores why audit assistants decide to leave the audit profession.

\footnotetext{
${ }^{5}$ For more details on each individual paper's theoretical perspectives and contributions, see appendix 1 and the appended papers, as well as the discussion in 6.4 .
} 
Purpose

Thesis

\section{Part I}

Holistic analysis study (triangulation of qualitative and quantitative data)

\section{Part II}

Qualitative study

Paper I

Paper II

Quantitative study I

Paper III

Quantitative study II
Chapters 1-6

To explore the meaning of professionalism, i.e. the occupational and normative values that constitute the professional narrative, and independence, i.e. conformity and deviance in relation to social identities, for the individuals within the audit arena.

To explore the social identities in play within the audit arena.

To explore Millennials' professional wants and needs and audit employment expectations and to discuss potential (mis)matches with audit firm reality.

To explore the perceptions of the audit profession among potential employees.

To explore the motivational drivers of audit employees.

To explore the association between job satisfaction determinants and junior auditors' actual decision to leave the audit profession.

In chapters 1 to 6 in this thesis, I take a holistic approach to the empirical material, where the 'combined' data from all four studies are used to explore the audit arena from a social identity perspective. In other words, I 'triangulate' qualitative and quantitative data and conduct a holistic analysis, where meanings are discerned from both narratives and 'numbers' (cf. Maschi, 2016). The empirical material in papers I and II is derived from interviews conducted during the spring of 2017 with accounting students who were about to enter the audit arena ${ }^{6}$, and in papers III and IV from two surveys sent to current audit staff, including audit assistants, auditors and partners, as well as former audit assistants during the spring of 2014 and $2015^{7}$. I view both interviews and surveys as narrations of social identities. In other words, both the interviews and

\footnotetext{
${ }^{6}$ Not all students entered the audit profession, nor planned to do so. However, these individuals provided an outside view on the audit arena, which did not substantially differ from those wanting to enter or entering the audit arena.

${ }^{7}$ For more details regarding the research process and data collection, see section 1.5.1.
} 
the surveys represent how the individual chooses to present her/himself and interpret the social group to which s/he belongs, as "[p]eople organize and construe the world in ways that reflect the groups to which they belong" (Haslam \& Ellemers, 2005, p. 53). Thus, the empirical material is here, in the holistic analysis, viewed as narratives of the social identities within the audit arena.

The empirical material provides both pre-socialized and post-socialized perspectives on the audit arena, where the bulk of the material stems from the pre-socialized perspective. The interviews gathered data on accounting students' career wants and needs, and perceptions of audit firms as employers (see interview guide in appended paper I and II). Appended papers I and II therefore provide insights into what the entrants into the audit arena expect and want from professional life as well as how they perceive the audit arena and the social groups within it. Social groups are not static; they change, more or less quickly and dramatically, as new members enter the group and others exit (cf. Moreland et al., 2001). The new generations of accounting students, with other needs than previous generations, have been argued to particularly influence the auditor identity within the audit arena, due to the audit firms' adaptations to their needs (Durocher, Bujaki, \& Brouard, 2016). Pre-socialized perspectives on the audit arena can therefore be seen as windows into potentially shifting meanings of professionalism, if entrants start with a different view of professionalism than the current professionals. These interviews also provide less sugar-coated pictures of the meaning of professionalism and independence as the accounting students have not yet been taught 'the rules of the game' of portraying a certain 'professional' front (cf. Alvesson, 2011). Hence, these interviews give insights into what the social identities of auditors, audit firms and the audit profession constitute 'behind the professional façade'.

The surveys gathered data on current audit staff's motivational drivers and current and former audit assistants' perceptions of the audit firms' work environment and other antecedents of job satisfaction (see appendix 1 and appended papers). This material does not represent a topmanagement-centric view, as more experienced audit staff, such as authorized auditors and partners are 'underrepresented'. However, Alvesson \& Robertson (2016) argued for more bottom-up studies on (social) identity in organizational contexts. The appended papers III and IV provides insights into the social identities within the audit arena through the collective goals, needs, and interests of the profession. Identification with social groups is generally associated with "a motivation to achieve group goals and work for the group's interest." (van Knippenberg, 2000 , p. 360), where motivation is ultimately driven by needs (Baumeister, 2016), and "group- 
based needs [...] play an especially important motivational role in situations where an individual's social identity is salient" (Haslam et al., 2000, p. 320). Appended paper IV also gives insight into less positive aspects of the social identities of auditors, audit firms and the audit profession as individuals exit social groups when they fail to provide a favourable identity (Tajfel \& Turner, 2004).

The empirical material can be viewed as stemming from liminal actors. Liminality is a concept that captures 'in-betweenness', where an individual goes through a rite of passage such as moving from one identity to another (Beech, 2011). The accounting students were liminal actors as they were soon to leave their identities as students and become employees; a passage involving identity reconstruction (cf. Beech, 2011; Borg, 2014) and socialization into new contexts (Moreland et al., 2001). The clear hierarchical structure of the audit firms creates liminality, as it creates expectations of moving relatively quickly to new roles and positions within the firm (cf. e.g. Anderson-Gough et al., 1998; Stenger et al., 2017), resulting in a possibly constant chain of identity reconstructions (cf. Alvesson \& Robertson, 2016). Audit assistants are in different stages of becoming full members of the profession, whereas auditors and partners may either be on route to partnership or preparing to leave the profession (cf. Moreland et al., 2001). Identity construction is related to the idea of sensemaking, i.e. "people interpreting phenomena and producing intersubjective accounts and meanings that help them in understanding and dealing with their experiences" (Tienari \& Vaara, 2016, p. 460). "Sensemaking is an issue of language, talk and communication"; thus, sensemaking is about "narrative-making" and identities are produced through socialization and collective narration (Tienari \& Vaara, 2016, p. 461).

This chapter presents and constitutes the substantive theory of the thesis, i.e. the theory connected to the peculiarities of the object of study, namely the audit arena (cf. Larsson, 1990: see figure 2). The social identity perspective is the conceptual theory ${ }^{8}$ through which the empirical data is analysed, and generalizations to a broader object of study can be made, namely professions, and other occupations as social groups. The substantive and conceptual theories are thus "related to one another through the pair general-particular" (Larsson, 1990, 9. 304). According to Larsson (1990):

\footnotetext{
${ }^{8}$ Conceptual theory is sometimes referred to as formal theory. For the sake of clarity and readability, I use the term conceptual theory.
} 
"The complementarity of the intersection of conceptual and substantive theories can be further seen in Israel's (1979a) discussion on identification with and as something. To identify something with something means identifying with something similar or common and therefore grouping them into the same category. To identify something as something means focusing what is specific, different, distinct, unlike. These two senses of identification logically presuppose each other, since in order to identify something with something, one must be able to identify it as something, and vice versa. An intersectional research object can be identified with conceptual theory and as substantive theory." (p. 304$305)$.

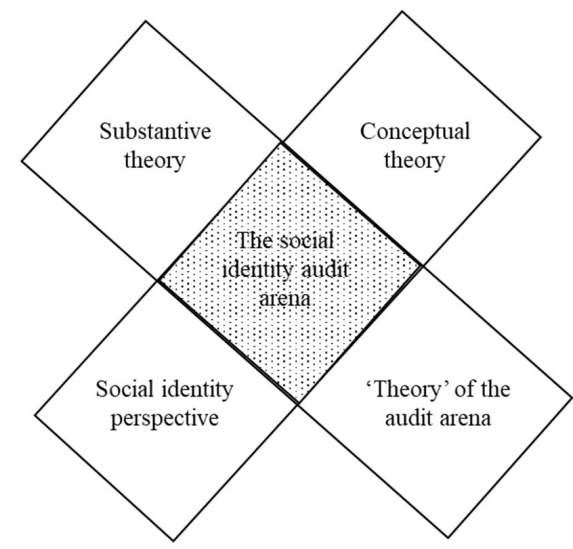

Figure 2: The theoretical framework of the thesis

The 'theory' of the audit arena is based on theories of professions, which in other studies can be viewed as conceptual theory, as it refers to generalizations across professions (cf. Larsson, 1990). However, in this thesis, the theories of professions are the empirically and contextually bounded theories, as they 'create' the audit arena (cf. Abbott, 1988; see figure 2). The social identity perspective is the conceptual, empirically, and contextually unbound theory in this context, as it generalizes group behaviour across empirical contexts (see chapter 3 for an elaborated discussion). Combining these theoretical perspectives allows us to both look at the 'particularities' of the actors within the audit arena, that sustain, create, and change the audit profession and generate both unintended and intended social outcomes (cf. Abbott, 1988; Hedström \& Ylikoski, 2010; Larsson, 1990), and the 'similarities' between the audit profession and other professions and occupations as social groups (cf. Larsson, 1990; also see e.g. Tajfel \& Turner, 1979). 


\subsubsection{The research process, design and method}

The research in this thesis is influenced by the pragmatic approach to the philosophy of science (cf. Johnson, et al., 2007), as I combine qualitative and quantitative studies and methods. The mixed methods approach is not only employed in terms of data collection and analysis. The thesis also "integrates findings from both quantitative and qualitative studies in a shared area of empirical research" (Onwuegbuzie \& Johnson, 2006, p. 53). Quantitative and qualitative methods have their own strengths and weaknesses (see e.g. Guyader, 2019 for this discussion), and mixed methods has been claimed to "improve [the] validity of theoretical propositions" and allows the researcher "to obtain a more complete (less biased) picture of the phenomenon under study than it is possible with a more narrow methodological approach" (Ihantola \& Kihn, 2011, p. 39). Thus, mixed methods provide 'breadth', i.e. 'better' understanding, a fuller picture and enhances description (Johnson et al., 2007). The appended papers therefore provide different and complementary perspectives on the audit arena, not only by providing 'pre-' and 'postsocialized' perspectives, but through the mixed methods approach (Van de Ven, 2007).

In the holistic analysis, the data from the qualitative and quantitative studies are presented in a reversed chronological order in terms of when they were conducted (see table 2). The overall research process started with the quantitative studies, which resulted in the appended papers III and IV. The data for paper IV was collected during the spring 2014 and for paper III during the spring 2015 by two of the co-authors, Nellie Gertsson and Josefine Friberg, for their bachelor and master theses. I was involved in the work with these theses in different ways. I provided feedback on the survey in paper IV before it was distributed, and I was involved in the data analysis phase in the spring of 2015 for paper III $^{9}$. The appended papers based on these theses were written together with Nellie Gertsson and Pernilla Broberg. Our collaboration started with one paper based on both surveys, which was presented at the 39th European Accounting Association Annual Congress in 2016 (see Gertsson et al., 2016), which mainly I and Nellie wrote in collaboration, which is reflected in the author-order. However, this conference paper was later developed into the two appended papers. Paper IV required particularly extensive revisions related to e.g. previous literature and theory and motivations of operationalization and

\footnotetext{
${ }^{9}$ Pernilla Broberg supervised these theses at Högskolan Kristianstad and was in the spring of 2014 also supervising me for my master thesis. I was thus asked if I could pre-test and provide input on the survey used in appended paper IV. In the spring 2015, I worked as a teacher at Högskolan Kristianstad and I helped Nellie and Josefine with how to conduct the statistical analysis of the survey data used in appended paper III.
} 
statistical methods applied, as e.g. the actual choice to leave the profession was used as a variable rather than the more commonly used variable turnover intentions. The revisions were mainly done by me and Nellie in collaboration, which is reflected in the author-order of the paper. During the review process I was responsible for writing responses on the reviewer comments as many were related to the statistical methods ${ }^{10}$. Paper III ended up being relatively similar to the thesis version, making my input in the published version of paper III less prominent than in paper IV, which is reflected in the author-order ${ }^{11}$.

Table 2: Overview of data collection, respondents, design, and method of analysis

\begin{tabular}{|c|c|c|c|c|c|}
\hline & \multicolumn{2}{|c|}{ Data Collection } & \multirow[b]{2}{*}{ Respondents } & \multirow[b]{2}{*}{ Design } & \multirow[b]{2}{*}{ Method of analysis } \\
\hline & Method & Conducted & & & \\
\hline Paper I & Interviews & $\begin{array}{l}\text { Spring } \\
2017\end{array}$ & Accounting students & $\begin{array}{l}\text { Cross- } \\
\text { sectional }\end{array}$ & Thematic analysis \\
\hline Paper II & Interviews & $\begin{array}{l}\text { Spring } \\
2017\end{array}$ & Accounting students & $\begin{array}{l}\text { Cross- } \\
\text { sectional }\end{array}$ & Thematic analysis \\
\hline Paper III & Survey & $\begin{array}{l}\text { Spring } \\
2015\end{array}$ & $\begin{array}{l}\text { Current audit } \\
\text { employees }\end{array}$ & $\begin{array}{l}\text { Cross- } \\
\text { sectional }\end{array}$ & $\begin{array}{l}\text { OLS regressions } \\
\& \text { exploratory factor } \\
\text { analysis }\end{array}$ \\
\hline Paper IV & Survey & $\begin{array}{l}\text { Spring } \\
2014\end{array}$ & $\begin{array}{l}\text { Current and former } \\
\text { audit assistants }\end{array}$ & $\begin{array}{l}\text { Cross- } \\
\text { sectional }\end{array}$ & $\begin{array}{l}\text { Logistic regression } \\
\& \text { exploratory factor } \\
\text { analysis }\end{array}$ \\
\hline
\end{tabular}

The quantitative studies are focused on factors explaining the variance of different outcomes (Van de Ven, 2007). However, they were explorative in nature, and therefore not just focused on hypotheses testing and explaining how independent variables explain variations in the dependent variable (see the statistical methods used in table 2). They were also used to discover interesting areas for qualitative research (cf. Creswell, 2014). Paper IV indicated that perceptions of the profession influence the decision to leave the audit profession. Paper III identified two motivational drivers not previously highlighted in the audit context, namely contributing to the client and the audit firm, and indicated motivational differences between small versus large office audit staff rather than between Big 4 and Non-Big 4 staff as indicted by the literature. These results inspired the qualitative study, and the aim was to further understand these results. In other words, the qualitative data was used to explore the quantitative

\footnotetext{
${ }^{10} \mathrm{I}$ redid all the statistical analysis for this paper as I at the time attended a doctoral course in statistics. Therefore, I became responsible for handling reviewer comments as I had all the 'nitty gritty' details top of mind in terms of the data, the statistical analysis, and the literature.

${ }^{11}$ In this paper, the authors after the first are listed in alphabetical order.
} 
findings (Wisdom \& Creswell, 2013) and thus it can be seen as sequential triangulation (Johnson, et al., 2007).

The qualitative study was not only designed to understand the results from the quantitative studies but designed from an interest in understanding how the audit firms' strategic communication with potential employees was perceived by the intended audience, as the firms' strategic communication must reflect both the values of profession and the individual audit firm (see paper II for an elaborated discussion). Therefore, studies, theories and concepts related to strategic stakeholder management, corporate and employer branding as well as employer attraction influenced the direction of the qualitative study. However, theories of professions, social identity theory and the writings of Goffman also came into in focus as the research was guided by the question why and how perceptions of the profession influence exits from the profession $^{12}$.

I conducted and designed the qualitative study independently, which is reflected in the singleauthored papers I and $\mathrm{II}^{13}$. I conducted interviews with students from three different universities in Sweden during the spring of 2017. These universities were purposely selected to represent different geographical locations and student groups with different socioeconomic backgrounds, as the local environment and the individuals' background may influence perceptions (cf. Saunders, 2012). All interviews were recorded and transcribed in verbatim and the data analysis followed the process of thematic analysis as described by Braun and Clark (2006). The recorded interviews were in total 3241 minutes and the transcribed material consists of approximately 616000 words. The interviews can be seen as narrative research as the respondents told their stories about why they chose to study accounting and what their career plans were (Creswell, 2014). According to Mills (1940), the motives through which we explain our actions are not given without a reason. In other words, we cannot get insights into individuals' real motives, but rather just observe the language people use when they account for and explain their reasons

\footnotetext{
${ }^{12}$ Initially, the plan was to conduct a study focused on former auditors to explore how former auditors experienced and managed the social identity reconstruction that comes with the exit from the profession.

${ }^{13}$ The observant reader can note that care has been taken to ensure the anonymity of the respondents. As the respondents' employers are disclosed in appended paper II, and the audit industry being relatively small in Sweden, the respondents have different IDs in appended paper I and II and no demographic background variables are disclosed in paper II. This was done in order to ensure that the respondents' quotations, demographics et cetera in the papers, as well in the holistic analysis, cannot be matched and potentially reveal the respondent's identity.
} 
(Alvesson \& Sköldberg, 2009). The qualitative material cannot be seen as representing 'truths', as the respondents cannot be seen as meaning exactly what they say and being willing or able to tell the 'true' story (Alvesson, 2011). However, the respondents' vocabulary of motives can "say a great deal about what is typical of the [...] occupational group in question" (Alvesson \& Sköldberg, 2009, p. 288).

\subsubsection{The empirical context}

In this thesis, the audit arena is explored in the Swedish context. As previously mentioned, auditor independence has been argued to be a cultural and cognitive concept, making the context in which auditor independence is discussed of importance (Hudaib \& Haniffa, 2009; cf. Kouakou et al., 2013). The Swedish audit arena is characterized by the profession being developed in the shadow of a strong state, which has resulted in auditors having additional responsibilities in comparison to their Anglo-Saxon and international counterparts (Öhman \& Wallerstedt, 2012). The Swedish audit arena has historically been and still is dominated by small audit firms, and small clients, as Sweden has lower mandatory audit thresholds than other countries, whereas research tend to focus on big accounting firms ${ }^{14}$ and on larger clients than in the Swedish context. The Swedish arena is also characterized by accounting and auditing being separate professions and the firms within the arena being audit rather than accounting firms. This indicates that the empirical context provides a scene that can provide new insights on social identities within the audit arena and auditor independence due to its peculiarities. The peculiarities of the Swedish audit arena context are therefore elaborated in the next chapter, but first, the remaining structure of the thesis is presented in the next section.

\subsection{The structure of the thesis}

The thesis focuses on the audit profession, rather than audit firms and individual auditors. However, as the audit profession is an abstract entity, meaning that no one entity embodies the profession (cf. Sellers \& Fogarty, 2010), one cannot explore the profession without exploring the meso-and micro-levels of the profession, i.e. the audit firms and the individual auditors. For readability and conceptual clarity, I will, as far as it is possible, discuss the profession as a macro-concept before discussing the audit firm and individual auditor levels in chapters 1 to 3 . In the empirical chapters (4 and 5), the text is structured from the micro- to the macro-level, as the data represents micro-level perceptions of the audit arena. In the concluding chapter 6 , I

\footnotetext{
${ }^{14}$ See the European Accounting Review's call for papers for the special issue on auditing edited by Canning, Malsch and O'Dwyer.
} 
will focus on the audit profession, and refer to the audit firms and individual auditors when necessary.

In chapter 2, the Swedish audit arena context is elaborated by giving a historical perspective on the Swedish audit profession, an account of more current changes as well as the differences between the Swedish and Anglo-Saxon context. Chapter 3 starts with an introductory note on the social identity perspective, which is followed by a section on social identities in professional and organizational contexts, where the concept of socialization is incorporated as it is through the process of socialization individuals become a part of a collective. Chapter 3 continues with a section on socialization into the audit profession, and it ends with a conceptualization of the audit arena from a social identity perspective. Chapter 4 provides the empirical account of the audit arena from a pre-socialized perspective, where the empirics from appended papers I and II based on interviews with accounting students are analysed from a social identity perspective. Chapter 5 provides the empirical account of the audit arena from a post-socialized perspective, where the empirics from appended papers III and IV based on surveys on current audit assistants, auditors, and partners as well as former audit assistants are analysed from a social identity perspective. Chapter 6 presents a discussion on the empirical narrative of the social identity audit arena and the meanings of professionalism and independence for the individuals within the arena based on the analysis. Chapter 6 also summarizes the conclusions of the thesis, and what we can learn from it theoretically, empirically, and practically. Chapter 6 also highlights suggestions for future research and the limitations of the thesis and ends with a personal reflection on the moral of the 'story'. 


\section{Chapter 2 - The Swedish audit arena}

This chapter sets the scene in which the appended papers have been conducted. First, a brief account of the historical development of the Swedish audit profession and the current state of the Swedish audit arena is given. Recent major changes within the audit arena are highlighted, as these changes occurred during the data collection and analysis of appended papers I and II, which has influenced the analysis and the author. The chapter ends with a discussion on the differences between the Swedish and the Anglo-Saxon audit arena, as the research on auditing and the audit profession is dominated by the Anglo-Saxon perspective on the audit profession. 


\subsection{How the Swedish audit arena came to be and where it is now}

The Swedish audit profession has developed in "the context of a strong state focused on protecting the public interest" (Öhman \& Wallerstedt, 2012, p. 242), resulting in Swedish auditors being required "to check their client's taxes, and they have crime-controlling responsibilities as they are obliged to report suspicions of crime to the authorities" (Broberg, 2013, p. 58). The earliest evidence of auditing in Sweden is in the 1650s (Agevall \& Jonnergård, 2013). With the increased separation of ownership and management during the 1850s and onwards, due to companies' increased dependence on outside capital, virtually all limited liability companies required auditing in their Articles of Association at the turn of the century (Öhman \& Wallerstedt, 2012). In the Companies Act of 1895, all limited liability companies were required to be audited. However, the auditor could be anyone as no particular education nor experience was mandated by law (Öhman \& Wallerstedt, 2012). The Companies Act developed over the years and larger and listed companies were in stages required to have more qualified auditors (Agevall \& Jonnergård, 2013), and in 1988, all limited liability companies had to be audited by authorized auditors (Prop. 1981/82:171). In Sweden, the audit has traditionally included a so-called 'management audit' (Burrowes \& Persson, 2000), where the auditor must give an opinion on whether or not the board and the CEO are granted discharge of liability (Broberg, 2013; Collin et al., 2017), i.e. whether the board and CEO has "contravene[d] the Companies Act or the Articles of Association of the company ${ }^{15}$ " (Burrowes \& Persson, 2000, p. 90) or not ${ }^{16}$.

A national audit body, named The Swedish Society of Auditors ${ }^{17}$, was created in 1899 (Wallerstedt, 2001). In 1912, the first authorization of auditors was created by the private sector and in 1923 a national audit body for authorized auditors (FAR) was created. These two bodies merged in 2006 and the state became responsible for authorizing auditors in $1975^{18}$ (Agevall \&

\footnotetext{
${ }^{15}$ Burrowes \& Persson (2000) cite an older version of the Companies Act (1975:1385); however, in the Companies Act (2005:551) the same applies.

${ }^{16}$ Other differences in the Swedish audit context, compared to other jurisdictions is that it is the general meeting of the shareholders that elect the auditors and non-listed companies do not need to have an audit committee. Thus, the management can influence the auditor choice in these companies (Carrington et al., 2013).

${ }^{17}$ Svenska Revisionssamfundet (SRS) in Swedish.

${ }^{18}$ From 1975 to 1995 , when Sweden joined the European Union, Kommerskollegiet was responsible for the authorizations. From 1995 onwards, it has been the Inspectorate of Swedish Auditors' (Revisorsinspektionen, previously known as Revisorsnämnden) responsibility (Agevall \& Jonnergård, 2013).
} 
Jonnergård, 2013). In Sweden, there have been two different auditor titles; approved and authorized auditors, where the authorized auditors had a higher audit degree. Before 2001, approved auditors were only allowed to audit smaller companies below certain thresholds ${ }^{19}$; however, as a harmonization with EU rules, the two titles were abolished (Agevall \& Jonnergård, 2013), and all auditors authorized by the new rules and former approved auditors ${ }^{20}$ are able to audit any clients (SFS 2001:883).

In 2010, the mandatory audit for small limited liability companies was abolished after several years of debate on the pros, i.e. decreased costs for the accountors, and cons, i.e. the risks of increased economic crime among the accountors and increased costs for society, i.e. accountees (Riksrevisionen, 2017). Limited liability companies are exempted from audits if they meet not more than one of the following criteria for two consecutive year; 1) 3 Million SEK in net turnover, 2) total assets of 1,5 Million SEK, and 3) on average 3 employees. For the reporting year 2015, approximately $60 \%$ of the active companies in this category chose not to be audited (Riksrevisionen, 2017). In other words, relatively small limited liability companies ${ }^{21}$ are mandated to be audited in comparison to EU legislation (SOU 2008:32). The current debate has been influenced by the report from Riksrevisionen (2017) that indicated that accounting quality in the smaller limited liability companies has decreased, which influences the work of the tax authorities and the government entities in charge of reducing economic crime. In other words, the abolished mandatory audit has resulted in more cons than pros than argued when the reform was implemented, and Riksrevisionen (2017) suggested that mandatory audits for all limited liability companies should be reinstated. However, the government decided not to reinstate mandatory audits for all limited liability companies (Callius, 2018).

In Sweden, the audit arena has historically been dominated by small audit firms. In the 1960s, the proportion of one auditor-firms was $65 \%$, in the 1970 s $57 \%$ and in $199981 \%$ (Wallerstedt,

\footnotetext{
${ }^{19}$ See the applicable version of the Companies Act (1975:1385) for these thresholds.

${ }^{20}$ In practice, there were two types of approved auditors; those with and without an auditor's degree. Those with an auditor's degree could audit larger and listed companies before 2001. Those who did not have an auditor's degree could not convert their title to authorized, but could keep their title as approved, and are thus still only allowed to audit smaller companies (for the current thresholds, see the current version of the Companies Act (2005:551)) . In May 2019, 376 auditors held the title approved auditor (Revisorsinspektionen, 2019-b).

${ }^{21}$ The threshold limits in Euro are (EUs limits in parenthesis): 1) total assets of 150000 EUR (3 650000 EUR), 2) net sales of 300000 EUR (7 300000 EUR) and 3) 3 (50) employees (on average) during the fiscal year (conversion from SEK to EUR based on $1 \mathrm{EUR}=10 \mathrm{SEK}$ ).
} 
2001). However, in the 1980 s, Swedish audit firms merged with each other as well as their international partners, which transformed the Swedish audit arena into a multinational highly competitive market driven by the big multinational companies (Agevall et al., 2017). These changes have altered the way in which the Swedish profession can market itself. According to Rahnert \& Brunsson (2019), FAR has been forced to adapt the rules for the way in which professional auditors may market themselves to the way auditors in practice have marketed themselves, and "the audit firms have placed the production of trust in the profession to FAR whereas they practise unbridled competition with each other" (p.63, my translation).

Three of the Big 4 firms have dominated the Swedish market, namely PwC, EY and KPMG. According to Wallerstedt (2001), all these three firms in Sweden have their roots in the first established Swedish firms in the early 1900s. Deloitte ${ }^{22}$ was relatively late in entering the Swedish market (Wallerstedt, 2001). As seen in table 1, PwC is the largest firm in terms of both turnover and employees in Sweden. In 2009, the number of auditors working at Grant Thornton was 229, in comparison to Deloitte's 153 auditors (Carrington, 2010). Deloitte and Grant Thornton are therefore relatively similar in size. The Swedish firms are in general similar in terms of the clients they serve. Even though the Big 4 firms audit most of the listed clients in Sweden (Carrington et al., 2013), as small companies dominate the Swedish economy, all audit firms are specialized in small client audits (Svanberg \& Öhman, 2015). In 2018, both PwC and KPMG sold their accounting and payroll services divisions to Aspia, as a part of their strategic plan to focus on auditing and more qualified advisory services (KPMG 2019; PwC, 2018).

\footnotetext{
${ }^{22}$ Arthur Andersen had a hard time reaching the same size as PwC, EY and KPMG due to an organic growth strategy (Wallerstedt, 2001). After Arthur Andersen's demise, the firm in Sweden merged with Deloitte (Carrington, 2010).
} 


\begin{tabular}{lccccc} 
& PwC & EY & KPMG & Deloitte & Grant Thornton \\
\hline $\begin{array}{l}2009^{\mathrm{a}} \\
\text { Turnover (Million SEK) }\end{array}$ & 4314 & 2700 & 1900 & 1410 & 865 \\
Nr of employees & 3600 & 1955 & 1500 & 1100 & 830 \\
& & & & & \\
$2013^{\mathrm{b}}$ & 4439 & 3300 & 2743 & 1461 & 1125 \\
$\begin{array}{l}\text { Turnover (Million SEK) } \\
\text { Nr of employees }\end{array}$ & 3897 & 2240 & 1500 & 1081 & 923 \\
& & & & & \\
$2017^{c}$ & 5269 & 3998 & 2385 & 2441 & 1368 \\
Turnover (Million SEK) & 3707 & 2458 & 1525 & 1224 & 1112 \\
Nr of employees & & & & & \\
& 5715 & 4217 & 2546 & 2635 & 1448 \\
$\begin{array}{l}2018^{c} \\
\text { Turnover (Million SEK) }\end{array}$ & 3900 & 2541 & 1539 & 1318 & 1171 \\
Nr of employees & & & & & \\
\hline
\end{tabular}

a) Carrington (2010), b) Carrington (2014), c) The annual reports for respective firm. Note that the firms have different year ends.

The accounting and auditing professions have been represented by different professional bodies. The title authorized accountant was launched in 2006 in Sweden (Srf konsulterna, n.d. -a) and authorized payroll consultant in 2013 (Srf konsulterna, n.d. -b). However, the national body for accountants was formed as early as 1936 (Srf konsulterna, n.d. -c). The national audit body FAR opened the organization for other members in two stages. Audit industry experts could become members in 2001 and other accounting professionals in 2010 23 (Agevall \& Jonnergård, 2013). The audit and accounting bodies had a collaboration regarding the authorization of accountants from 2009, but it was terminated in 2017 (FAR, 2017). No official reason for the termination was given. However, there are some indications of disagreement. The press releases from both parties announcing the terminated collaboration indicates that FAR and SRF disagreed on how to support their members in adjusting to the digitalized environment (FAR, 2017; Srf konsulterna, 2017). Also, some developments driven by Srf konsulterna had not been implemented, for example corroboration around the authorization of payroll consultants and an improved Swedish standard for accounting and payroll services (Lagnehag Zars, 2017). This terminated collaboration has resulted in two different

\footnotetext{
${ }^{23}$ This happened at the same time as the mandatory audit for small limited liability companies was abolished.
} 
authorizations of accountants; ARK by FAR and Rex by Srf konsulterna ${ }^{24}$. The initiation of the title authorized accountant can be seen as an attempt to professionalize accounting. At the same time as this professionalization of accounting took place, FAR promoted the idea of the auditor and authorized accounting consultant as the client's personal trainer (cf. Brännström, 2016), which is a discourse connected to client-service rather than a public service ethos.

\subsection{Current larger changes within the Swedish audit arena}

During 2017, the Swedish Inspectorate of Auditors initiated a change in the competence demands for becoming an auditor (Johansson, 2017) and these changes were implemented in July $2018^{25}$ (RIFS 2018:1). One of the arguments for these changes was to increase the attractiveness of the profession to ensure its future. The Swedish Inspectorate of Auditors claimed that the educational system for auditors cannot deliver enough authorized auditors. From having been on a stable level of 4000 authorized auditors or above (Svanberg \& Öhman, 2015) since the early 1990s (Revisorsinspektionen, n.d.-a), the number of authorized auditors has decreased to below 3200 in April 2019 (Revisorsinspektionen, 2019-a).

\footnotetext{
24 The different authorizations require different educational and competence demands in order to be authorized; demands that changed at the time the collaboration ended. FAR demands three years of university education, whereas Srf konsulterna demands two, but both accept a 2-year vocational education, and both now only require three years of practical experience instead of five. Previously, those with long practical experience in accounting could be awarded an authorization even if they lacked the necessary education, if the practical experience was at least twelve years. Both bodies have now lowered it; FAR only demands seven years of experience, whereas Srf konsulterna demands eight years (see FAR, n.d.; Srf konsulterna, n.d. -d). Srf konsulterna specifies certain courses as mandatory and offers an authorization education that can substitute the education required (Srf konsulterna, n.d. $-\mathrm{d})$.

${ }^{25}$ Sweden has had higher competence demands than required by EU legislation. The total length of the education was eight years, of which minimum 3 years of university studies and a minimum of 3 years practical education. Certain university courses were mandated, i.e. you had to have 90 credits business administration with courses in accounting, group accounting, auditing, finance, management control and organizational theory, 15 credits tax law, and 30 credits business law. It was also mandatory to have studied information technology, economics, mathematics, and statistics either as integrated subjects in the business administration program or as standalone courses. The new regulation is more in line with EU requirements (at least a bachelor's degree and a minimum of three years practical education). In addition, the mandatory university course credits are no longer specified and the theoretical knowledge requirements for the authorization can in some extent be acquired through the audit firms or other educational providers such as FAR (Revisorsinspektionen, 2017).
} 
The Swedish Inspectorate of Auditors argued that these changes would increase the attraction of the profession and attract auditors with the broader competences necessary in the age of digitalization, without decreasing audit quality, as it would not decrease the knowledge required in practice (Revisorsinspektionen, 2017). These changes were debated in several seminars and in industry magazines during 2017 and 2018 and the suggestions were criticized mainly by academics for various reasons. Marton (2018) pointed out that decreasing the education by $25 \%$ and deemphasizing the need for conceptual knowledge may increase the profitability of the profession in the short term, but not in the long run as there is a risk that trust in the profession will decrease. It is paradoxical then, that it is the Swedish Inspectorate of Auditors driving the changes, whose function is to promote the control function of the audit rather than the profitability of the firms (Marton, 2018).

Broberg \& Tagesson (2017) argued that trying to attract individuals with a broader educational background could decrease the status of the occupation since a common competence base is a key characteristic of professions. They also pointed out that analytical abilities are required by auditors and sought by the business sector; these are skills that are trained at the advanced levels in higher education. Hence, requiring auditors to have at least a master's degree, rather than just a bachelor's, as in the new requirements, would increase the status of and attraction to the profession (Broberg \& Tagesson, 2017). It was also argued that the firm's recruitment communication, where the work is depicted as something anyone, regardless of educational background, can learn, does not attract the best and the brightest, as these individuals are rather attracted to selective employers (Sylvander, 2018; cf. Trank et al., 2002) and that the 'up-orout' incentive structure may be a potential cause for why the profession has issues with retaining competent staff (see paper I for an extended discussion). Not only academics saw potential issues. The Secretary General for FAR at the time, Dan Brännström, pointed out the importance of dialogue within the profession and warned of 'firm bubbles', i.e. that audit employees are educated only within their own firm (Hadjipetri Glantz, 2017).

The Swedish Inspectorate of Auditors has also recently changed the requirements of continuous education and conducted audit work in order to keep the audit authorization. The motive for this change was to provide an easier route back to the profession for those who have left and been away more than five years. Instead of counting hours of continuous education and conducted audit work, the Inspectorate will do a more qualitative assessment of returning auditors education and experience (Hadjipetri Glantz, 2019-a). These changes were not as heavily debated as the changed competence demands and the new rules were implemented in 
July 2019. These changes and the debate at the time are relevant for understanding the context of the thesis, as the interviews in the appended papers I and II were conducted during the time of this debate and change.

\subsection{Differences between the Swedish and Anglo-Saxon audit arena}

Research on auditor identities and socialization in accounting is dominantly conducted in an Anglo-Saxon setting (see e.g. Andersen-Gough et al., 1998; Bamber \& Iyer, 2002). The theoretical assumptions in the social identity perspective are assumed to hold over contexts. However, as previously stated, auditor independence is a cultural and cognitive concept (Hudaib \& Haniffa, 2009); hence, the context matters. Differences between the contexts may also have implications for how social identities are understood (cf. Haslam \& Ellemers, 2005). For example, the Anglo-Saxon literature uses a different nomenclature to that used in the Swedish language. In English, accounting is a broad umbrella term. The Anglo-Saxon accounting profession incorporates all individuals working in accounting, regardless of whether they are preparers or auditors of the financial statements, and even accountants working in private firms are seen as a part of the profession. In Swedish, there is a vocabulary difference between preparers of financial reports, i.e. bookkeepers and accountants ${ }^{26}$, and auditors. This difference is not just vocabulary; accountants and auditors are generally not seen as belonging to the same profession (cf. Carrington et al., 2013) and the Big 4 accounting firms are referred to as audit firms in Sweden. Also, accountants working in private firms are generally not seen as members of the profession, as they are in the Anglo-Saxon context (e.g. Stocks \& Hardin, 2001). It is those that work in accounting and audit firms that are members of the accounting and audit profession and that can become members of the professional associations. Also, the authorization differs between the Anglo-Saxon countries and Sweden, since there is no equivalent to the Certified Public Accountant (CPA) exam in Sweden; it is rather two authorizations - one for accountants and one for auditors. Even if the national professional audit body has become more of an accounting body, accounting has not been viewed as a profession,

\footnotetext{
${ }^{26}$ The bookkeeper records the day-to-day transactions, whereas the accountant prepares the annual reports. In Sweden, the term 'redovisare' is often used, meaning anyone involved in the financial reporting process, i.e. bookkeepers and accountants. For laymen, auditors are often seen as accountants (or even bookkeepers). However, for those within the field, bookkeeping and accounting are two different occupations (even if the accountant may do the work of a bookkeeper to some extent). The use of the term accountant in this section refers to those who prepare the annual reports.
} 
perhaps due to the historical separation between the occupational groups and the vocabulary distinction between auditing and accounting.

Bamber \& Iyer (2002) argue that individuals develop a professional accounting identity long before they formally enter the profession and the organizations within the arena, as they typically decide on becoming CPAs long before joining an accounting firm. CPAs are also claimed to keep their CPA certification and association membership when leaving the profession for private firms. These claims do not hold in the Swedish context. Many Swedish students choose the university programs in business administration, since they provide a broad education, allowing a postponement of the choice of a future occupation. Accounting courses and other courses needed for the auditor authorization are chosen out of interest or to keep the option of starting at an audit firm open ${ }^{27}$. Nor can Swedish auditors keep their authorization when they leave the profession ${ }^{28}$. The audit work experience is therefore more highly valued than the authorization, as audit experience is valued by private industry and opens doors for other career paths (cf. Steenackers et al., 2016). It is therefore doubtful whether Swedish students identify themselves with the profession during their studies. It is more likely that their identities are more connected to them being students and business students in particular. This suggests that the audit firms may play a bigger role in shaping auditor identity than the research in the Anglo-Saxon context suggests, since the students' decision to become an auditor is made in the later stages of their education, i.e. when it is time to get a job. Hence, the audit firms' narratives of the audit arena may particularly influence the way that students perceive the audit arena (cf. Lievens \& Slaughter, 2016).

Employment contracts at the trainee level in Sweden are different to Anglo-Saxon employment contracts. Swedish employee rights are quite strong and the possibility to employ people on short-time contracts is limited. Additionally, Sweden has a relatively high proportion of union members in comparison to other European countries (Isaksson et al., 2003). Newly graduated

\footnotetext{
${ }^{27}$ These arguments are based on both the interviews conducted for this thesis and personal communication with students in general. The interviews and personal communication with audit employees also indicate that firms hire students who do not have all the mandatory courses; however, they are expected to pass these courses if they want to become authorized.

${ }^{28}$ SFS 2001:883 33§ (4§ states that the Swedish Inspectorate of Auditors can give individuals exemptions from the requirement to be an active auditor, which in practice means working $50 \%$ with audits - see Revisorsinspektionen, n.d. -b).
} 
students or entry-level audit staff are offered full-time permanent contracts with a six months' probation period. Contracts in the Anglo-Saxon countries rather seem to be short-term training contracts (cf. Anderson-Gough et al., 1998; Steenackers et al., 2016). This could influence identification, since the level of 'security' of the membership in the profession and organization varies (cf. Jenkins, 2008). However, even though legal employment contracts differ, the overall organizational and employment structures in the Big 4 firms are similar to the Anglo-Saxon countries (Carrington et al., 2013). Even if the Swedish Big 4 firms claim not to have the "upor-out' incentive structure, it is present in practice (Lennartsson, 2018).

The Nordic labour markets have been claimed to be similar to the UK labour market but different from the US market, as EU legislation has applied to both the UK and the Nordic countries (Eskildsen et al., 2004). In the Anglo-Saxon context, it has been claimed that an advantage of employment in a Big 4 firm is compensation and benefits (Bagley et al., 2012). In the US, entry-level staff in the Big 4 firms receive an annual salary of between 45000 and 60 000 US dollars depending on the department and location of the office, but in Canada and the UK the salaries are slightly lower than in the US (Corporate Finance Institute, n.d.). In Sweden, the entry-level audit staff receive an annual salary ranging between 27600 to 32400 US dollars (276 000 SEK to $\left.324000 \mathrm{SEK}^{29}\right)^{30}$. Hence, audit employment is not well compensated in Sweden in comparison to the Anglo-Saxon context ${ }^{31}$. Even though audit firms are attractive employers in Sweden, the firms have a harder time attracting students for audit employment when the economy is booming, i.e. as the Big 4 audit firms recruit many students every year, other jobs are more attractive during periods of economic prosperity, and audit firm employment is more attractive when the economy is declining ${ }^{32}$.

\footnotetext{
${ }^{29}$ The exchange rate is approximately 1 US dollar=10 SEK in the beginning of May 2019.

30 This information is based on personal communication with audit staff and the interviews conducted for this thesis. According to Civilekonomerna, the average monthly salary for newly graduated business students in audit firms in 2018 was 26123 SEK (Hadjipetri Glantz, 2019-b). As in the US, salaries depend on the location of the office where you are hired. Big city offices have higher salaries as the living costs are higher.

${ }^{31}$ Compared to the US, the average salaries in general in Sweden are relatively similar. Living costs differ between the US and Sweden, where some costs are lower in the US and other costs are lower in Sweden. However, overall, the living costs seem to be relatively similar (see Nationmaster.com for a comparison). However, the tax and welfare systems between the countries differ, and it is therefore hard to determine the extent to which the salaries differ in real terms.

${ }^{32}$ This is based on personal communications with senior accounting academics in various parts of Sweden.
} 
To summarize, the Swedish audit arena has some particularities which may influence how social identities are to be understood. Accountants and auditors do not belong to the same profession, as in the Anglo-Saxon context. However, due to the abolishment of the mandatory audit for small limited liability companies, the Swedish professional audit body is becoming more similar to its Anglo-Saxon counterparts, as it now includes both accountants and auditors. Nevertheless, both PwC and KPMG have discontinued their accountancy departments, which can be interpreted as them seeing auditing and accounting as two different occupations and professions. The Swedish business environment is characterized by small companies, and historically the audit arena has included a large proportion of small audit firms and there are still many small audit firms. The clients in the audit arena are predominately small ownermanaged firms in comparison to the Anglo-Saxon context, as mandatory audit thresholds are low in international comparison. In comparison to the Anglo-Saxon context, Swedish entrylevel audit employees are not trainees in terms of their legal employment contracts, even if they are trainees in practice. As Swedish firms offer permanent employment contracts and Swedish employers have few legal possibilities to fire permanent staff ${ }^{33}$, the 'up-or-out' system may even be harsher than in the Anglo-Saxon context, as 'social outcasting' or straight-out bullying may be the only way for firms to get rid of unwanted staff. Salaries in Sweden are low in comparison to the US, UK, and Canada, and to other entry-level jobs in Sweden business administration students can get (Civilekonomerna, n.d.). This may induce higher levels of employee turnover and increased perceptions of audit work as a steppingstone to something else, making liminality a greater issue, which should influence how social identities within the audit arena are understood.

\footnotetext{
${ }^{33}$ Legal reasons for dismissing permanent staff are lack of work and personal reasons. Personal reasons are misconduct, difficulties in cooperating, refusal to work, harassments or not being loyal to the firm (Ledarna, n.d.).
} 


\section{Chapter 3 - The audit arena from a social identity perspective}

This chapter introduces the social identity perspective; the conceptual theory used in the analysis of the empirical material. The chapter starts with an introduction to the social identity perspective, followed by a section on social identity in professional and organizational settings. As socialization is important in the formation of identities in professional and organizational settings, the socialization process into the audit profession is discussed in a separate section. The chapter ends with a summary of both the substantive and conceptual theory by a conceptualization of the audit arena from a social identity perspective. 


\subsection{An introductory note on the social identity perspective}

Taking a social identity perspective involves incorporating social identity theory (SIT) and selfcategorization theory (SCT); two theories that share many assumptions (Hornsey, 2008). The theories also share "methods and emerge from the same ideological and meta-theoretical perspective" (Hornsey, 2008, p. 207). The theories emerged and developed in the field of social psychology and "capture the socially embedded, situated, shared, social, group-located properties of human beings." (Turner \& Reynolds, 2012, p. 1).

The concept of social identity was first introduced by Tajfel in 1972 (Hornsey, 2008), and later developed by Tajfel \& Turner (e.g. 1979) and "[t]he core idea [..] was that groups are not only external features of the world, they are also internalized so that they contribute to a person's sense of self" (Haslam \& Ellemers, 2005, p. 41). Social identity refers to the identities shared by members of groups which distinguish them from other groups (Ashforth et al., 2008). According to Ashforth \& Mael (1989), in order for an individual to identify with a group, the individual must "perceive him- or herself as psychologically intertwined with the fate of the group" (p.21); however, no interaction between group members has to occur in order for the individual to perceive her/himself as a part of the group. Tajfel \& Turner (2004) argues that individuals strive to maintain or enhance their self-esteem. Individuals therefore strive to achieve a positive social identity that is based on a favourable comparison of the social identity and relevant outside groups, which enhance the positive aspects of the social identity. If one fails in creating a positive social identity, individuals either exit the social group or try to enhance the positive aspects of the social identity (Tajfel \& Turner, 2004) by e.g. changing the outgroups of comparison (Tajfel \& Turner, 1979) or "by stubbornly maintain favorable identities and ingroup bias even in the face of evidence indicating that their group is low in status, power or prestige" (Jost \& Elsbach, 2001, p. 187).

SCT can be seen as a further refinement of SIT and focuses on the psychological processes that determine when individuals act as individuals and when they act as group members (Turner \& Reynolds, 2012). SCT shares the core assumption in SIT that humans have both a personal (individual) and social (group) identity. However, SCT also assumes that we can define ourselves at different levels of abstraction, i.e. "define oneself as an individual, as a member of particular groups in contrast to others and as a member of higher-order more inclusive groups", where, "[m]ore inclusive self-categories define what is socially negotiated and affirmed as being valued, appropriate and right.” (Turner \& Reynolds, 2012, p. 7). Different identities are invoked in different situations, based on their salience, i.e. "the identity's subjective importance 
and situational relevance" (Ashforth \& Johnson, 2001, p. 32). Identity salience explains how a particular context is given meaning, as the context triggers self-categorizations that fit the perceived reality (Turner \& Reynolds, 2012).

SIT and SCT acknowledge that individuals do not possess one holistic self, but rather a multifaceted self, consisting of different identities (Ashforth \& Johnson, 2001). Individuals possess as many identities as memberships and social categories which they identify themselves with, but they can combine these into one holistic (multifaceted) identity (Ashforth et al., 2008; cf. Brewer, 1999) or keep them separate from one another (Kreiner et al., 2006; cf. Brewer, 1999). Social categories are defined by "the prototypical characteristics abstracted from its members" (Ashforth \& Mael, 1989, p. 20) and they serve two functions. They help individuals to cognitively order the social world, as they provide individuals with "systematic means of defining others" and to "locate and define him- or herself in the social environment" (Ashforth \& Mael, 1989, p. 21). Stated differently; “[s]ocial categorizations [define] people's place in society and through being internalized into the self, together with their emotional and value significance, [provide] people with social identities." (Turner \& Reynolds, 2012, p. 3). Thus, intergroup behaviour is not only motivated by self-esteem, but also by uncertainty reduction as "[s]elf-categorization reduces uncertainty by transforming self-conception and assimilating self to a prototype that describes and prescribes perceptions, attitudes, feelings and behaviors." (Hogg \& Terry, 2001, p. 6). "[P]rototypes that are simple, clear, highly focused, and consensual $[\ldots]$ provide a powerful social identity" as groups with high entitativity are very cohesive, thus providing better uncertainty reduction (Hogg \& Terry, 2001, p. 6).

Identification with social groups influences behaviour, and "social identity is the cognitive mechanism that makes group behavior possible" (Turner, 1982, p.21 cited in Haslam \& Ellemers, 2005). Research has, for example, shown that individuals tend to favour ingroup members in relation to outgroup members, i.e. group identification creates biases and discriminatory behaviour (see e.g. Tajfel \& Turner, 2004). Whether or not an individual identifies with a social group is dependent on the context, and the context also determines the content of the social identity (Haslam \& Ellemers, 2005). Thus, the influence of the social identity on behaviour is contextually dependent, as the context determines which ingroup/outgroup comparisons are made (Haslam \& Ellemers, 2005). Hence, the professional and organizational context matters, which is highlighted in the next section. 


\subsection{Social identities in professional and organizational contexts}

In professional and organizational contexts, individuals occupy many different identities, where the identities can be derived from groups such as the organization, the department, and the work-team (Ashforth \& Mael, 1989) or groups outside organizational boundaries, such as industries, strategic alliances (Ashforth \& Johnson, 2001) or professions (cf. Abbott, 1988). As in other contexts, different identities are invoked in different situation based on their salience (Ashforth \& Johnson, 2001, p. 32) and are enacted through identity markers, such as physical appearance, surroundings, performance outcomes such as quality and quantity, and behaviour (Ashforth et al., 2008), where the distinctiveness of the group's values compared to other groups increases the tendency to identify with the group (Ashforth \& Mael, 1989).

According to Haslam \& Ellemers (2005, p. 53), "social identity serves to regulate individual cognitive activity not only by providing a shared perspective on social reality and a common set of experiences but also by providing a basis for mutual social influence.". In other words, the social categories people share create expectations of consensus about relevant issues for the social identity, and thus motivate individuals "to strive actively to reach agreement and coordinate their behavior in relation to those issues." (Haslam \& Ellemers, 2005, p. 53). It is in this process that norms may become shared, consensual, and socially organized, and "personal opinion can become social fact" (Haslam \& Ellemers, 2005, p. 53). In professional and organizational contexts, this process can be viewed as socialization, as socialization is "the process of learning the appropriate way of doing things, of learning how to be in a certain environment, of internalizing the norms, values and beliefs of a culture" (Anderson-Gough et al., 1998, p. 22). Socialization is both the formal and informal processes that enable individuals to become functional members of a social group (Anderson-Gough et al., 2000).

Professional socialization refers to the process of becoming a member of a profession and beginning to identify oneself as being a part of the profession (Heck, 1995) and has been described as "the acquisition of the values, attitudes, skills and knowledge" that characterize the profession (Siegel et al., 1991, p. 58). Professional socialization starts during university studies (Siegel et al., 1991), and continues in the organizational context where the professional role is learned, i.e. what it is that the professional should do and how s/he should do it (Van Maanen \& Schein, 1979). SIT has been questioned by researchers arguing for system justification theory. The central tenet in this critique is that SIT fails to recognize differences in status and power between groups (Jost \& Elsbach, 2001), which is particularly relevant to consider in a professional context as professions are internally stratified (Abbott, 1988). The 
assumption of ingroup bias arguably does not hold when status and power differences are included to predict group behaviour as low-status groups have been shown to display positive outgroup biases and high-status groups to be far more likely to engage in discrimination (Jost $\&$ Elsbach, 2001). However, the critique is based on a misinterpretation of SIT, as a central tenet in SIT is that the influence of the social identity on behaviour is contextually dependent (Haslam \& Ellemers, 2005). Therefore, the differences in status and power are important to consider in professional contexts.

Professionals are not only socialized into professions, but also into the employing organization, and it is through the organization that individuals meet the profession (cf. Anderson-Gough et al., 1998; Sellers \& Fogarty, 2010). Research has shown that organizational socialization primarily occurs in formal or informal work groups, since the relationship between the individual and the organization is impersonal in most organizations (Moreland et al., 2001). As socialization revolves around the acquisition of values, attitudes et cetera, the socialization process is directly related to identification. For example, research has shown that individuals who identify with the group in which they are socialized, adjust to the group more quickly than individuals who identify less with the group (Chatman, 1991). As individuals are part of different groups (cf. Ashforth \& Johnson, 2001), organizational socialization involves socialization into several groups, which in ideographic organizations, where groups are less similar, makes the socialization process complex (Moreland et al., 2001). Organizational socialization has been defined as "the process through which one is taught and learns the particular knowledge and skills of an organizational role in a specific work setting" (Heck, 1995 , p. 33). Hence, organizational socialization is a more specific socialization within a particular setting. However, professional and organizational socialization are interrelated, since it is within an organizational setting the individual experiences the profession (AndersonGough et al., 1998).

Socialization in organizational contexts can be seen as built on three psychological processes; evaluation, commitment, and role transition (Moreland et al., 2001). Evaluation is a process where the individual and the group assess the other party's contributions to the group's goals or satisfaction of personal needs (Moreland et al., 2001). Evaluations are not limited to the present interaction but also involve retrospective and future orientations, where past and future behaviour is assessed. Commitment is influenced by these evaluations, and becomes stronger if the past, present and future relationship is perceived as more rewarding than other past, current, or possible relationships (Moreland et al., 2001). When commitment changes, role 
transitions may occur if the changes are large enough, which transforms the relationship between the individual and the group. These role transitions can be viewed as rites of passage between different phases of group membership, "separated by four different role transitions (entry, acceptance, divergence, and exit)." (Moreland et al., 2001, p. 93). Role transitions can be seen as liminal phases, where individuals are 'in-between' identities moving from an outsider to an insider, to a full member of the group, to a marginal member and from an marginal member to an outsider (cf. Moreland et al., 2001), where the professional identity is reconstructed in each phase (cf. Beech, 2011; Borg, 2014). Role transitions and identity reconstruction also occur in the progression through the organizational hierarchy, where individuals "adapt to new roles by experimenting with provisional selves that serve as trials for possible but not yet fully elaborated professional identities" (Ibarra, 1999, p. 764). As the particular context matters, the socialization into the audit profession is discussed in the next section.

\subsection{Socialization into the audit profession}

Within the professional and organizational audit context, social identities are nested, where the teams and the office where one works are less inclusive groups, i.e. where group membership is restricted to a limited number of individuals. The employing audit firm, the global employing audit firm network, the 'Big 4' network (elaborated on later in this section), and the profession are more inclusive groups, (cf. Ashforth \& Johnson, 2001: see figure 3). In other words, the more inclusive social groups include more individuals than the less inclusive groups such as the office and the team, and group boundaries become less 'defined' the more inclusive the social group is. 


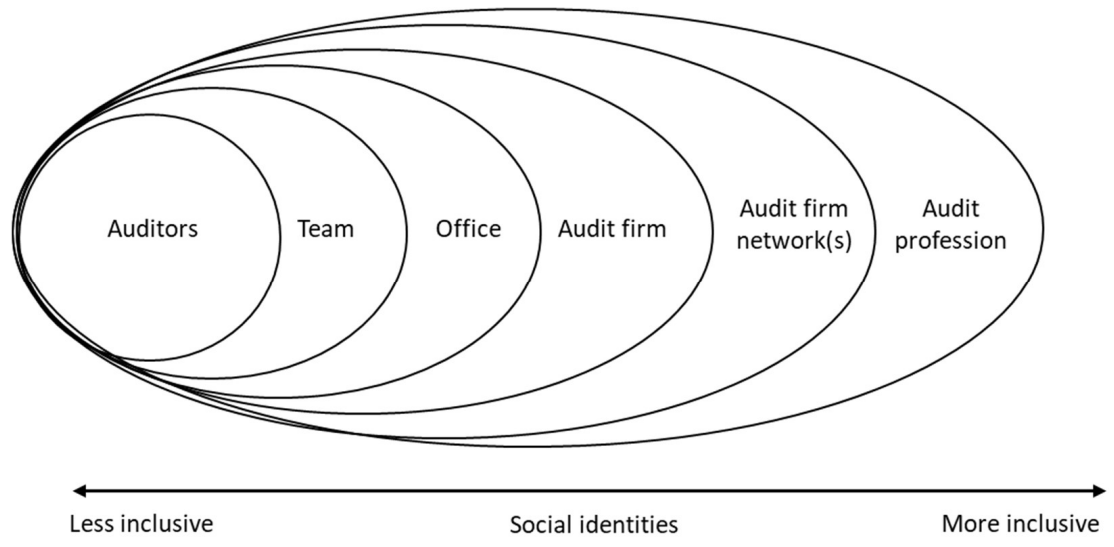

Figure 3: Social identities within the professional and organizational audit context

Individuals are mainly socialized into social groups within the audit teams, the office where they work, and the employing firm, i.e. at the micro- and meso-levels of the audit profession. Hence, it is these contacts and interactions within the socialization process that shape the audit profession (cf. Abbott, 1988; Hedström \& Ylikoski, 2010; Larsson, 1990; cf. figure 1 in chapter 1), and where the values, attitudes, and behaviour that the social group 'the audit profession' prescribes are created (e.g. Siegel et al., 1991). The prescribed values, attitudes and behaviours are what constitute the professional narrative (cf. Evetts, 2011; chapter 1).

Within the audit firm and the audit teams, the individual auditor ${ }^{34}$ goes through several role transitions and phases of identity reconstruction (cf. Beech, 2011; Borg, 2014; Moreland et al., 2001), as audit firms have clear hierarchical career paths. Their career 'system', the up-or-out model, is used as an instrument for socialization, "through which individual behavior is shaped and firms' values and conceptions of the ideal professional are conveyed." (Stenger et al., 2017, p. 4; cf. figure 1 in chapter 1). Hence, the audit firm structure serves as a coercive mechanism through which socialization occurs (Fogarty, 1992). The 'up-or-out' system creates

\footnotetext{
${ }^{34}$ One formally becomes an auditor when one passes the authorization exam. However, all audit team members can be viewed as auditors. The team members that clients most encounter during the audit are those that do the actual audit work, which usually are other team members than the authorized (signing) auditor. In my experience, the public does not distinguish between e.g. an audit assistant and an authorized auditor. Anyone working with auditing is rather viewed as an auditor. Hence, in this thesis, all individuals hired by an audit firm to work with auditing are viewed as auditors.
} 
expectations of having to move up the corporate ladder as it does not allow individuals to stand still, creating 'constant' liminality until the partner-level is reached (Kornberger et al., 2011).

Even though labelled differently, the audit firms have the same career path. First one becomes an assistant. The assistant is trained and socialized in the same 'program' as others, where "individuals are guided through formal rules regardless of context and individual future ambitions" (Lokatt, 2018, p. 149). According to Coffey (1994), these junior auditors ${ }^{35}$ are socialized into seeing time as a core professional value, making managing time and looking or being busy important professional traits, fostering them into entrepreneurial thinking (also see Anderson-Gough et al., 2001). Therefore, junior auditors are expected to work long hours to show their commitment to the audit firm and the profession (Anderson-Gough et al., 1998; Grey, 1998; Coffey, 1994). The early stages of the career are focused on 'looking and acting the part', i.e. having an appropriate dress code both at work (Grey, 1998) and in private life (Covaleski et al., 1998) and speaking and conducting oneself in an appropriate manner (Anderson-Gough et al., 2002), especially in front of clients (Anderson-Gough et al., 1998). "In other words, the early formative years in the career of accountants transform them into performers who are able to act out the script delineating what it means to be a professional convincingly." (Kornberger et al., 2011, p. 515).

In the next career stage, one becomes a more senior assistant, where the focus is on becoming authorized, and when having been authorized one transitions into a managerial role (Carrington, 2010). According to Kornberger et al. (2011, p. 514) "managers experience a fundamental transition, [...] a rite of passage" when moving in to the managerial role, where "the world of junior accountants is deconstructed and newly promoted managers learn to brace themselves for the complexities that constitute the organizational realities of a Big 4 Accounting Firm.”. Becoming a manager has been described as climbing a mountain and a hard transition, as "managers had to juggle multiple roles, including managing a team of juniors; acting as point of contact for clients; reporting to partners; and ensuring that projects were on track and being delivered on time and on budget." (Kornberger et al., 2011, p. 522). Hence, being socialized as

\footnotetext{
35 Junior auditor is a common term in the literature. However, it sometimes refers to lower-level staff who are junior in terms of tenure, but it can also be viewed as those who have not yet passed their auditor authorization exam (see appended paper IV). I view junior auditors as those who have not yet passed their exams, and in appended paper IV the term 'audit assistants' reflects this meaning.
} 
a manager involves learning to "perform, play games, and engage in politicking" (Kornberger et al., 2011, p. 530; cf. Carter \& Spence, 2014).

The next career stage is becoming a partner. Only those few who possess the 'right' characteristics are promoted to partner (Stenger et al., 2017); those that have been able to create a reputation of being good performers and profitable investments among current partners (cf. Anderson-Gough et al., 1998; Lokatt, 2018). Those who reach the partner-level are those who embody entrepreneurialism (Covaleski et al., 1998) and client service (Anderson-Gough et al., 2000). Partners who are experts on technical issues are in a minority, whereas the majority are those who "embody a social personality and [are] able to show good numbers" (Audit partner quotation in Lokatt, 2018, p. 154). Technical experts, who take the expert career track (cf. Lokatt, 2018), tend to stay in senior positions just below partner, because they tend to focus less on new client acquisition (Carter \& Spence, 2014). Partnerships are thus limited to those who are good salespeople, as technical competence is assumed at the partner level (Carter \& Spence, 2014).

The socialization process for junior auditors during the first few years within the profession is claimed to be "well documented" (Brouard et al., 2017, p. 234), however, research has focused on professional and organizational socialization in the Big 4 context (cf. Ramirez, et al., 2015), rather than socialization into specific teams and workgroups (cf. Garcia-Faliéres \& Herrbach, 2015; cf. figure 3). Also, it is claimed that "[i]n the accounting domain, only a few studies have employed the concept of organizational identification" (Garcia-Faliéres \& Herrbach, 2015, p. 755). The field rather focuses on commitment to the audit firm, which includes commitment to clients and the commercial value of the authorization, and the profession, which includes commitment to independence (Garcia-Faliéres \& Herrbach, 2015; cf. Suddaby et al., 2009).

The audit profession has often been argued to be homogenous as individuals 'converge' to professional norms (Gendron \& Suddaby, 2004); however, "the profession is typically described as, over time, becoming ever more fragmented" (Carrington et al., 2019, p. 1079). The audit profession can thus be seen as an amalgam of different social categories (cf. figure 3), which may influence the socialization process and individuals' ideas about who and what an auditor is. The Big 4 firms are also big global networks, making social identities and socialization into the profession 'filtered' through the employing firm and its network, as well as the 'Big 4' idea of the profession, as the Big 4 as a group influence standard-setting and professional practice (cf. Brouard et al., 2017; Cooper \& Robson, 2006; Muzio \& Kirkpatrick, 
2011; see figure 3). Hence, the 'Big 4' idea influences individuals regardless of being employed in a Big 4 firm or not. However, the profession may consist of subgroups with different power and status besides the subgroups Big 4 and Non-Big 4 auditors (cf. Carrington et al, 2019; Ramirez et al., 2015), as the Big 4 firms are multidisciplinary firms, where auditors are only one profession ${ }^{36}$ or occupation within the firms, which may create different social groups to those highlighted in this section.

The nested social identity structure within the audit profession makes socialization into the audit profession a complex matter, as auditors are not just socialized into the profession and a particular audit firm and its network(s), but into a particular office and different teams (see figure 3), and possibly other social categories, which can only be determined empirically, as especially Big 4 audit firms are multidisciplinary firms. Auditors can also identify with social categories outside the profession and the audit firms. As auditors serve particular roles for accountors and accountees, these actors may be social categories that auditors identify with. The next section discusses these social categories which auditors can identify with and conceptualizes the audit arena from a social identity perspective.

\subsection{The social identity audit arena}

To summarize the social identity perspective and the 'theory' of the audit profession in chapter 1 , the audit arena can be viewed as a nested social identity system (see figure 4), where the socialization of individuals into the profession may involve identification with different social groups both within the profession, such as teams, offices and audit firms, and audit firm network(s). However, identification with social actors outside the profession, such as accountors or accountees, can also occur if the individual auditor shares characteristics or 'social labels' with them and if these 'social labels' are salient in the audit context, creating identities that cross-cut professional and organizational boundaries (see figure 4; cf. GarciaFaliéres \& Herrbach, 2015; section 3.1. and 3.2.).

\footnotetext{
${ }^{36}$ Audit firms also employ individuals with legal expertise, i.e. from the law profession (cf. Alvehus, 2006), and management consultants, who can be viewed as 'semi-professionals' (cf. von Nordenflycht, 2010).
} 
Social identity influences on auditor behaviour

(a) Social identity influences from a public interest perspective

(b) Social identity influences from a business perspective

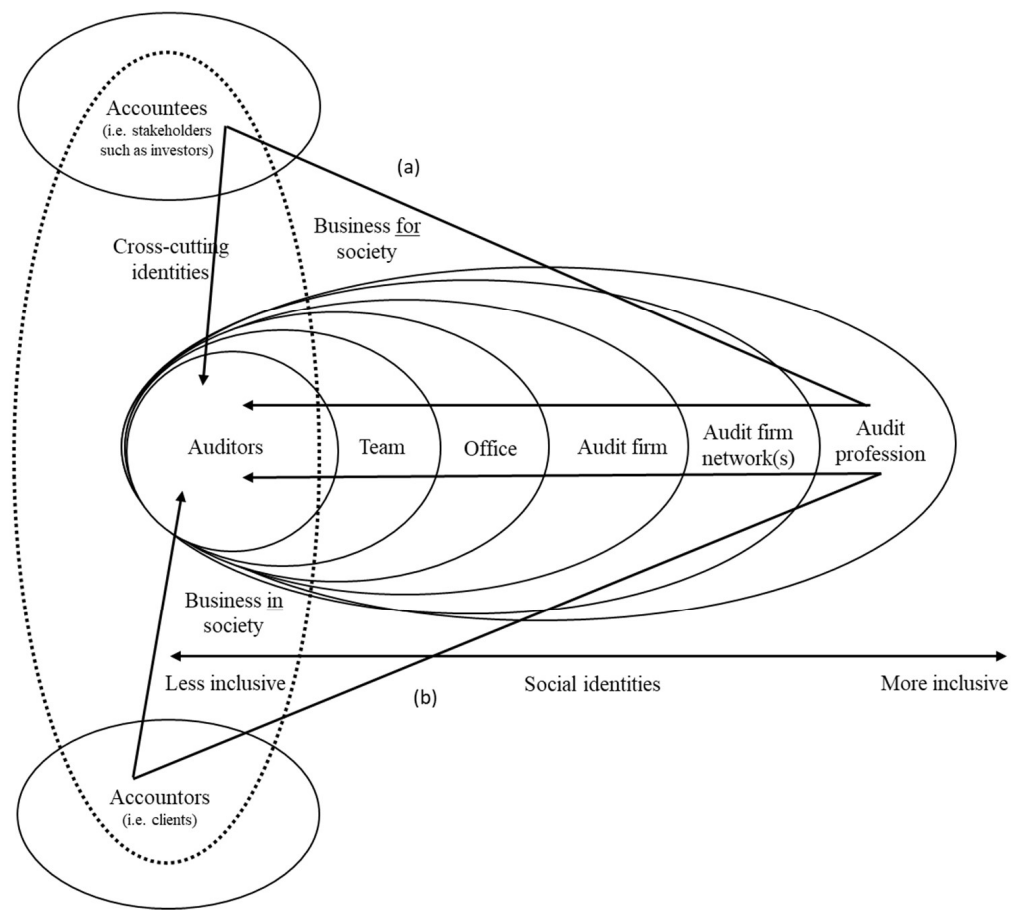

Figure 4: The social identity audit arena (a development of Öhman (2007)'s audit arena)

According to Warren \& Alzola (2009, p. 45), “[i]dentification with client firm has long plagued the auditing industry". Client (i.e. accountor) identification occurs as a result of auditors working closely with clients and often at the client company, possibly leading to knowing the accountor better than one's employer (cf. Alvesson, 2000), or by auditors viewing accountors as potential future employers, where client tenure, importance and image positively influence identification (Bamber \& Iyer, 2007; see (b) in figure 4). However, this research assumes that accountors are a homogenous group, whereas "contemporary audit work is fragmented, particularly in terms of institutional arrangements for different client types." (Carrington et al., 2019, p. 1080). Different clients may thus create different social categories which auditors may identify with, and thus influence auditors' perceptions, attitudes, values, and behaviour differently (e.g. Hogg \& Terry, 2001), and in return influence meanings of professionalism and independence (see (b) in figure 4). 
Depending on the client type, who the main accountee is can be discussed ${ }^{37}$. For listed and public interest companies, the main accountees are existing and potential investors, lenders, and other creditors (IASB, 2018). However, for small and medium-sized enterprises (SMEs), where agency relations between owners and managers are less prominent or non-existent (as in ownermanaged firms), the main accountees may rather be lenders, creditors, and tax authorities (cf. figure 4). To the best of my knowledge, social identity research in the audit context has not considered that different types of accountees may influence auditor (social) identities ${ }^{38}$. Hence, the audit arena from a social identity perspective should include different types of accountors and accountees as potential social categories influencing auditors' perceptions, attitudes, values, and behaviour (e.g. Hogg \& Terry, 2001) and meanings of professionalism and independence (see (a) in figure 4).

\footnotetext{
${ }^{37}$ There are more client types in the audit arena than those discussed here. For example, public sector organizations are another client type; a type that distinguishes itself from the profit-maximizing client types mentioned in the text. For public sector organizations, the main accountees are the voters/taxpayers/individuals that finance and are served by this sector. For readability and conceptual clarity, a wider range of client types is not incorporated in the text.

${ }^{38}$ However, Broberg (2013) indicates that in everyday auditor work, the accountees do not seem to be explicitly considered.
} 


\section{Chapter 4 - Pre-socialized narratives of the audit arena}

This chapter analyses the qualitative interviews with accounting students entering the audit arena, which the appended papers I and II are based on. This chapter discusses the findings in these papers from a social identity perspective, and additional data from the interviews are presented and analysed. The empirical data from these interviews provide insights into what the entrants into the audit arena expect and want from professional life as well as how they perceive the audit arena and the social groups within it. Durocher, Bujaki, \& Brouard (2016) argues that future auditors influence the auditor identity within the audit arena. Pre-socialized perspectives on the audit arena can therefore be seen as windows into potentially shifting meanings of professionalism, if entrants start with a different view of professionalism than the current professionals. These narratives on provisional selves entering the audit arena and the social identities within the audit arena also provide less sugar-coated pictures of the meaning of professionalism and independence as the entrants have not yet been taught 'the rules of the game' of portraying a certain 'professional' front (cf. Alvesson, 2011). 


\subsection{Narratives of (provisional) selves entering the audit arena}

The accounting students were outsiders becoming insiders, or in other words, prospective members as they had not yet formally entered the audit arena. These prospective members entered the arena with the idea that they were inexperienced and not knowledgeable, despite having a university degree. This idea was promoted primarily by senior members of the profession and personnel involved in recruitment. This rhetoric created a perception of (junior) auditors needing and having to learn, and therefore having to be driven by development opportunities. The individuals entering the arena were Millennials, a generation claimed to possess a high sense of entitlement, and who value work development (e.g. Winter \& Jackson, 2016) and all respondents stressed their need for development. Audit firms were therefore seen as workplaces where prospective members could fulfil their need for development (see paper I).

The auditor has traditionally been viewed as a dull bean counter, prompting the profession to depict itself as a fun and exciting workplace (Jeacle, 2008). Even though audit work was viewed as social, and less dull than the respondents generally thought before entering higher education, the majority of respondents describe themselves in what would be called traditional bean counter characteristics. They were individuals who like structure, order, clarity, or things being 'right or wrong/black and white', and described themselves as meticulous, nerdy, or as liking numbers. For example, the following respondents described themselves as follows (see paper I for respondent demographics):

[When describing her first impression of auditors] It is like everyone says, stiff [giggles] a stiff person with a briefcase that walks around, but I had no idea of what people with a business administration degree actually do. [But when you started working, did that image change?] Both yes and no I would say. I still think that auditors... no, but you have to be strict and orderly, but it is like you see the people [behind the work] and what they do, so [my view] has changed a bit. But I understand what people mean when they say that [auditors] are boring [laughs], I am a bit boring myself [...] I am a bit nerdy like that, I do not think it is boring [...] but I can see why others see it as [boring], well, I do not really know how to express it, but it is not like this very spontaneous and 'hopping about' occupation really. (R17)

[Why did you choose the education you did?] Well, it is like... it is not like I have known all along what I would become. But math has always been easy for me, and I think is fun with numbers [laughs], so that was sort of the reason from the start. (R21) 
I chose accounting [as my major] because... first of all I like to count more than I like to read and write, and it seemed like the other majors, marketing, and management, was more about reading and writing. It was like... no thank you. [...] But what was crucial was that it was more counting in accounting, and then that it is more law in accounting, I think that is fun. (R42)

[How would you describe yourself as a person?] Yes... I think I'm pretty... pretty kind, pretty openminded, I think. I'm usually meticulous... pretty ambitious regarding things that engage me [laughs]. I also like structure. That is about it. (R47)

The Millennial generation is often claimed to be a generation wanting to save the world (e.g. Durocher, Bujaki, \& Brouard, 2016). However, the respondents did not stress this as a prominent part of who they were ${ }^{39}$. The respondents rather depicted themselves as individuals wanting to matter as unique individuals, and having their work valued by either the firm or the 'customers' they serve. The prospective members therefore entered the audit arena with a 'customer' service ethos rather than a public service ethos (see paper I). This seems to be due to how the social identities of auditors, audit firms and the profession are perceived, which are presented in the next sections.

\subsection{Narratives of auditors}

Most respondents entered higher education with a stereotypical image of auditors, i.e. middleaged, introvert, and well-dressed men doing solitary office work (cf. Richardson et al., 2015); an image that changed during their studies (see paper II). Many respondents expressed that they did not know what auditing was or what the difference between accounting and auditing was when starting the education. As they had mainly encountered book-keeping in their previous education, the perceptions were generally that auditing is about 'number-crunching'. During the education, contact with audit firm employees either in the education (i.e. guest lectures etc.) or in recruitment situations (e.g. student activities, job fairs, etc.) changed the image for many respondents into an image of auditors as more 'social beings' and as intelligent, and often

\footnotetext{
${ }^{39}$ The respondents generally viewed CSR as only connected to environmental issues and audit firms were seen as service firms with little environmental impact. The respondents therefore did not see CSR as particularly relevant for audit firms.
} 
charismatic individuals who need to possess social skills in order to handle relations with clients, expressed by respondent 53 as follows (see paper I for respondent demographics):

[Before you started your studies, did you have an image of the typical auditor?] Yes, absolutely, it was someone who was quite... stiff [laughs] and just goes on numbers and facts. But I have gotten a different image now. The occupation... you meet a lot of different types of people, different types of entrepreneurs, so you cannot be an asocial person, rather you have to be able to adapt to different people and manage yourself in different situations. That is just as important as being able to audit the company.

As audit firms were perceived as workplaces where prospective members can fulfil their need of development (cf. paper I), auditors were viewed as knowledgeable teachers, and the audit firms as 'business universities', as auditing is the science of how companies work (see paper II). However, auditors were not only viewed as teachers for the junior auditors; they are also those teaching clients how to run their businesses (cf. Gertsson, 2018; Malmström, 2018):

[What makes auditing appealing work?] Well, it is probably that it feels like auditing... is the 'finest' [laughs] so to speak. [Is an auditor the best you can become?] Yes, that is why I want to see if I can make it, and it will be a challenge. I love challenges [laughs], and to see... well when you succeed with something, you are like proud of yourself. [...] I have thought that I wanted to become a teacher before, it was something I considered. That [work] is about correcting others... well, you help [people]. I love organizational theory and leadership, that has been my favourite course so far, and as an auditor, you go in and 'well here I see that something is missing, do like this instead, this is a suggestion', and you check how they use their systems, it is like being a teacher. (R20 - extended quotation from paper II - see paper II for respondent demographics)

[Do you see your tax authority work experience as valuable for audit work?] Yes, I think so. Everybody runs into tax issues as an auditor. And on a more personal level, it is quite enjoyable...you get to train at meeting people. [...] you get a lot of stupid questions [laughs] and you get to train [answering those], you have to learn to convey financial information and rules and regulation to people that have no knowledge and who are not interested at all, I think that is an important lesson. That is somewhat what you do as an auditor, [you try] to get [people] to understand what they are doing. (R25 - see paper I for respondent demographics) 
The majority of the respondents therefore saw the role of the auditor as being the entrepreneur's 'sounding board' or business consultant, and the auditor was sometimes described as a salesperson:

The [office]manager at [a Big 4 firm], he said, an auditor is also a salesperson. You have to be able to promote yourself to be able to promote the audit firm, so you find creative solutions to how to attract more customers and get customers to stay. (R39 - see paper I for respondent demographics)

To summarize, the dominant view of the auditor social identity among the respondents was the social, knowledgeable consultant auditor, who teaches and helps entrepreneurs run their companies more efficiently. However, this 'pure' social auditor identity rather represents the partner-level staff. The traditional bean counter identity coexists with this identity, creating the auditor identity of the 'social bean counter' which represent audit staff that are not partners nor partner material (see paper II; cf. Anderson-Gough et al., 2000; Covaleski et al., 1998; Lokatt, 2018).

\subsection{Narratives of audit firms}

As previously mentioned, the respondents predominantly described the audit firms as educational providers, rather than as audit firms. In other words, the pre-socialized narratives depicted the audit firms as 'business universities' who educate the current and future leaders of business society, rather than as providers of an assurance service (see paper II; cf. section 4.2). However, the pre-socialized narratives of the audit arena suggest that the individual audit firms are not distinct unique social groups as the respondents did not "express a clear and strong set of coherent beliefs about attributes" distinguishing the individual audit firms from each other (Alvesson \& Robertson, 2016, p. 165; cf. Martin et al., 1983; see paper II).

During the second year [of my education], I thought about whether I should pursue an audit career. And then I actively search for information, so I have talked to [Grant Thornton] and the Big 4. And yeah, I spend 10 weeks at [one Big 4 firm] in a work integrated learning course, and that was the first real insight into what auditing was, so to speak. I tried to find out what... what it is that sets [the firms] apart, what the pros and cons with [the different firms] are, and how the first years look like. I was fortunate to end up at [the Big 4 firm during the work integrated learning course], as it gave me a pretty good insight into how it looks at the Big 4. Based on what friends and people have told me about how it is at the 
other Big 4 firms], they do not differ that much, the Big 4. (R26 - see paper I for respondent demographics)

The respondents did however express differences between the Big 4 firms and the mid-tier firms (mainly Grant Thornton and BDO). The Big 4 firms are generally described as firms characterized by an 'American' culture, i.e. a competitive, hierarchical, and 'tough' environment, whereas the mid-tier firms are described as having a 'Scandinavian' culture, i.e. an open non-hierarchical and responsive environment (see paper II for illustrative quotations; cf. paper I). Smaller audit firms were also described as having a 'Scandinavian' culture, but even Big 4 firms were sometimes described in a similar manner. The Big 4 and Non-Big 4 social groups were therefore not clear social categories, and the characteristics of the social groups depended on what type of office the respondents had in mind when describing the group:

[What is it that distinguishes the audit firms from each other?] Yes... [that's] hard...overall, the only thing I think of when I think about the Big 4 firms is like... it is pretty standardized, and it is hierarchical. It is like, 'well, I am the signing [auditor], you are an audit assistant, do this. This have to be done on Monday, you have to work on Sunday'. But it is hard to say, I have not been at many offices, so it is hard to say how offices differ. I suspect that even within the Big 4 firms, there are big differences between offices. Like... [one] PwC [office] can be very similar to an office in BDO, maybe. Even if they are in different towns [Why do you think that there can be similarities, what makes them similar?] Well, it is... [...] I think it depends on the size of the office and those who work there. The only experience I have is that I have been at [a Big 4 firm office], and they were about fiftysixty [employees] here in [smaller Swedish town]. Not big, not small, but like a 'inbetween' office. There I experienced that it was...you had like a life outside of work, it was a pretty good atmosphere and not so ... high average age among the employees. It was very cordially and engaged, you really got to know everyone and talk to everyone. Then we were at [another Big 4 firm in same town], it was like, you do not know where to go, you were a bit confused and [the people] were not as engaged [...], it was like closed doors and felt more strict in a way, more hierarchical. But that was a bigger office. (R47 - see paper I for respondent characteristics)

The respondents expressed similarities between small offices in Big 4 firms, mid-tier firms and smaller audit firms, as well as similarities between big offices in mid-tier firms and Big 4 firms. The reason for these similarities is due to the general idea that small and mid-tier audit firms serve small clients and Big 4 firms serve large (public) clients. However, as larger clients are 
concentrated in the larger cities, the respondents saw smaller Big 4 offices (located in smaller towns) as serving a larger proportion of smaller clients and large Mid-tier offices (located in larger towns) as serving a larger proportion of larger clients compared to the 'prototypical' firm office. For example, respondent 18 expressed it as follows (see paper I for respondent demographics):

[Do the mid-tier firms differ from the Big 4 firms?] No, well... if you do not consider the big offices in Stockholm and Gothenburg, they work with the public listed companies, the smaller firms do not work with listed companies, but if you want to work with [SMEs], there is no real difference [between the firms].

Hence, what clients the office serves provides a clearer distinction between social groups than the firms do, which suggests that 'the small client auditor' and 'the large client auditor' are more salient social identities within the Swedish audit arena than the organization (cf. paper II). This has implications for how accountors and accountees are perceived, which is presented in the next section.

\subsection{Narratives of accountors and accountees}

The prominent accountor in the respondents' descriptions was the 'entrepreneur' or 'the ownermanaged firm ${ }^{40}$. Entrepreneurs and owner-managed firms were described in the same way, namely as clients where the traditional agency relation between (diverse and/or public) owners and managers was lacking, and entrepreneurs/owner-managed firms were equated with Small and Medium-sized entities (SMEs). Very few respondents touched upon large (public) clients as accountors in their descriptions of the Swedish audit arena. As the audit arena is perceived as dominated by SME accountors, the accountee became 'invisible' or abstract for the respondents. In the SME client context, the accountor was the accountee, and thus the party who should benefit from the audit. Therefore, the auditor's responsibility and public service was to help the SME grow, and become a more efficient company. In doing so, the auditor worked for the public interest by creating job opportunities, increasing taxes paid, and increasing the gross national product, expressed for example as follows:

\footnotetext{
40 The majority of the respondents expressed a desire to work with owner-managed firms/SMEs/entrepreneurs, whereas only a few seemed to prefer working with large (public) companies, regardless of what audit firms they preferred or were hired at. However, those who preferred the mid-tier firms often stated that it was due to them serving smaller clients.
} 
[Would you like a job where you contribute to society in some way?] Yes, I would, and I think you get that in auditing. Above all, I'm thinking of all these small companies that are not at all knowledgeable in business administration, that both accountants and auditors help a lot, enabling them to continue their enterprises and like work in a correct way, without there being any taxman or whatever [laughs] that will come and control them. So, you are like providing the benefit of letting them keep doing something they love. There are many who have their own companies, who are driven by having their own companies, even if they are not knowledgeable in business administration. That societal benefit, I feel, is fun to contribute with, because I think they show a lot of gratitude, like they feel a relief and can relax and focus on their work, which perhaps reduces stress and such, as they do not want to do it themselves. (R39 - see paper I for respondent demographics)

I have thought a lot about [the societal benefits of auditing], what is it that an auditor does really? He audits the numbers and how much does that contribute to really? But then of course, if you dig a bit deeper, it does contribute to society a lot. But if you compare to like a doctor or...[...] someone who really helps people, an individual like... yes, you are an auditor and you help large companies somewhere and yada, yada, yada,[ ...] [Do you feel you can provide more benefits to the smaller companies as an auditor?] Yes, I would say so... the direct impact feels larger when it comes to smaller firms, because then ... your actions... say that you tell a CEO in a large company that "no, you should report it like this instead of like this, you cannot do like this', then they might ... nothing happens, it feels like more weight is put on the auditor's comments in a small company, than in a large one. (R49 - see paper I for respondent demographics)

The above quotation from respondent 39 highlights the only accountee recognized by a few respondents in relation to small clients, namely the tax authority. As Swedish auditors are responsible for checking the 'correctness' of clients' tax payments to the authorities, there has historically been something of a stereotypical image of auditors being 'police officers', which to some extent is still prevalent in the Swedish context (Ekelund \& Stepien, 2016). As the 'guardian of the markets' idea was not prevalent among the respondents, investors and capital markets were not seen as relevant accountees within the Swedish audit arena, even though the role of the auditor in creating better capital markets was to some extent recognized. These perceptions of who the relevant accountors and accountees are influenced how the audit profession was viewed which is presented in the next section. 


\subsection{Narratives of the audit profession}

Based on the respondents' descriptions, the audit profession is a stratified profession, as the respondents perceived audit work to be different depending on whether the client is an SME or a large (public) firm (cf. Abbott, 1988). This might explain why the social groups 'small client auditor' and large client auditor' seem to be more salient identities than the audit firms. Audit work with small clients is not just about assuring information, but also about consulting the client, as the previous section highlights. From the prospective members entering the audit profession perspective, the first few years of audit work when working with smaller clients enables them to understand the audit from a holistic perspective, as they are allowed to do 'broader assignments' and understand the clients from a 'broader view', whereas working with larger clients involves a higher degree of specialization or 'routine' work, i.e. auditing a particular account, such as accounts receivable (see paper II). However, the respondents did not see this stratification as based on status differences, as many of them valued and wanted to engage in small client audit work. However, there are some indications in the empirics that large client auditors and Big 4 firms view small client auditors as lower-status auditors:

[What is it that sets the firms apart?] No, [nothing] really, and that is what they say themselves, when I have asked 'is there a difference between the firms' or 'why would you choose one firm over another', then they say 'there are no big differences' [But do you perceive that they market themselves in different ways?] Yes, in a way, KPMG I would say has a lot of these case-days [...] and they appear to be more of a 'competition'-firm, prestige, and status and all that. Maybe it is just me, but that is the [impression] I got. And these smaller clients like [Grant Thornton] works with would be less... well, not as prestigeful, it's like those at KPMG would say 'well, well [said ironically], you work at GT', a bit like that... [giggles] (R1 - see paper I for respondent demographics)

It feels like working as an auditor in smaller towns, it is like everyone knows everyone, you know who runs this and that company, it is more like... call it a 'buddy'-relationship with the clients or customers in another way than in the big cities. A partner I talked to at Deloitte in Stockholm stated when I said that I had been at one of their smaller more local offices; 'well, the question is if they conduct audits or if they consult, the auditors there'. It felt like the partner implied that it is more about helping the clients there rather than auditing them in a way. (Quotation from paper II from R9 - see paper II for respondent demographics) 
The majority of the respondents perceive the audit profession as making little or no contribution to society, other than helping entrepreneurs grow and have 'healthy' companies, expressed for example as follows:

[When discussing contributing to society as a motivational driver] For me it is first and foremost the personal development that is a driver. I would say that auditing is not a socially beneficial profession like doctors or lawyers. Well, doctors save lives and lawyers make sure that the justice system works in the way that it should. Auditors [laughs] verify and ... the whole profession verifies and corroborates financial information. That is something you could have the tax authority or the Financial Supervisory Authority to do. (R50 - see paper I for respondent demographics)

The public interest service auditing should provide therefore seems to be too abstract a notion to influence the social identities within the audit arena. As previously mentioned in section 4.1., even though the respondents are a generation who are claimed to want to save the world, being able to contribute to society is seemingly not an important driver for them, and contributing to the client is a more tangible benefit of the profession (see paper I), thus influencing the social identities within the arena in a more substantial way (cf. paper II). The question now remains whether the pre-socialized perspective on the audit arena paints a different picture from the post-socialized perspective, which is presented in the next chapter. 


\section{Chapter 5 - Post-socialized narratives of the audit arena}

This chapter analyses the quantitative surveys of current and former audit staff, which the appended papers III and IV are based on. The empirical data in paper III is self-reported perceptions of what it is that motivates current audit staff in their work and in paper IV current and former audit staff's self-reported perceptions of the profession, the work conditions and environment within the audit firms. This chapter discusses the results and findings in these papers from a social identity perspective. Hence, the data is seen as narratives on collective goals, needs, and interests of the profession, as identification with social groups generally is associated with "a motivation to achieve group goals and work for the group's interest." (van Knippenberg, 2000, p. 360), where motivation is ultimately driven by needs (Baumeister, 2016), and "group-based needs [...] play an especially important motivational role in situations where an individual's social identity is salient" (Haslam et al., 2000, p. 320). 


\subsection{Narratives told by current staff of auditors, audit firms and the audit profession}

The current staff within the audit arena depicted themselves as individuals most motivated by contributing to the client, autonomy, interesting work, growth and learning, variety, expertise, recognition, and challenging work, and least motivated by competition, organizational image, and status (see table 2 in paper III). Overall, this narrative corresponds with the pre-socialized narrative, as the client seems to be the main actor shaping auditors' self-image. It also reflects the idea of the auditor as an 'expert', who engages in varied and autonomous work, and who constantly needs to educate her/himself (cf. chapter 4). Audit staff are relatively highly motivated by good relationships with colleagues, flexible work hours, appreciation, working in a professional atmosphere, meaningful work, social interactions, being 'in on things', working in a clean, safe and modern environment, and being able to help and teach others (see table 2 in paper III). This narrative corresponds with the pre-socialized perceptions of auditors as 'social beings' (cf. chapter 4, Jeacle, 2008; Richardson et al., 2015) and being teachers for juniors and clients.

The current audit staff's narrative suggests the main goal of the profession being contributing to the client as it is the strongest motivational driver for audit work and seems to be what makes work interesting and challenging (see paper III; cf. Haslam et al., 2000; van Knippenberg, 2000). As needs are directly related to motivation (Baumeister, 2016), it suggests that contributing to the client fulfils the individual's need for growth and learning, meaningful work, and helping and teaching others. Current audit assistants perceived the profession as providing a sense of meaning, status and prestige, societal benefits, expertise, and career development (cf. paper IV). The majority of the current audit assistants were Millennials (64,9\% - see Gertsson et al., 2016), and audit Millennials seem to derive their sense of meaning from contributing to the client (cf. chapter 4). This suggests that the current audit assistants perceived the profession as providing a sense of meaning and societal benefits through contributions to the client, making the clients the most salient social group within the audit arena (cf. chapter 4; Agevall \& Jonnergård, 2013; Warren \& Alzola, 2009). As the Swedish audit market is dominated by small clients (cf. chapter 2), and prospective employees seem to see more sense of meaning in contributing to smaller clients than larger clients (cf. chapter 4), the SME client seems to be the most prominent social category influencing auditors' sense of identity within the Swedish audit arena.

The post-socialized narrative points to no differences between Big 4 and Non-Big 4 audit staff (see table 6 in paper II), but points to differences between individuals working in small and 
large offices ${ }^{41}$. Audit staff working in larger offices were more motivated by social drivers than audit staff working in smaller offices. This means that large office staff were more driven by mentoring, feedback, being treated fairly, constructive criticism, 'receiving' loyalty from the firm, good relations with the immediate manager and other employees, and clear rules and instructions than small office employees. Depending on how one views motivation, these results can be interpreted in different ways regarding what it is that characterizes the social groups small office auditors and big office auditors. Motivation can be seen as "broad, dispositional tendencies", i.e. that motivation refers to general needs guiding actions in most instances (Baumeister, 2016, p. 2). Viewed from this perspective, 'big office auditors' as a group seem to be characterized by needing development, a good social environment, and fairness and structure to a higher degree than 'small office auditors' (cf. paper III). The individuals who reside in the big office context can therefore be seen as having self-selected into that environment as the environment can fulfil these needs (cf. Baumeister, 2016). However, motivation can also be viewed as stemming from needs not being fulfilled, i.e. that individuals deprived of satisfaction start craving the dissatisfied needs even more (cf. Baumeister, 2016). From this perspective, big offices do not seem to fulfil individuals' needs for mentoring et cetera (cf. paper III; cf. Bagley et al., 2012), thus indicating these environments as being characterized by non-responsiveness (cf. paper I) to a higher degree than smaller offices within the audit arena.

Audit staff working in larger offices were more motivated by material and status drivers than audit staff working in smaller offices (see paper III). In other words, 'big office auditors' were more driven by monetary gains, promotion and growth, organizational image, high status, competition, pride, and achievement than audit staff working in smaller offices. As larger (Big 4) offices can be claimed generally to be associated with higher prestige, monetary gain, promotions and growth, (cf. Bagley et al., 2012) as well as competition (cf. Stenger et al., 2017), this suggests that individuals seek the environment that satisfies their needs, rather than motivation being representative of unsatisfied needs. As larger (Big 4) offices are associated

\footnotetext{
${ }^{41}$ Small offices are defined in paper III as offices with ten or less employees (not only audit staff). The respondents working in smaller offices were not just staff from small audit firms, as four of the respondents worked at small Big 4 firm offices. Also, 32 respondents worked in larger offices in the Mid-tier firms (these statistics are not shown in paper III). Worthy of note, there is an error in paper III. The majority of the respondents worked in NonBig 4 audit firms $(65,6 \%)$, not Big 4 firms as stated in the paper.
} 
with better training (cf. Bagley et al., 2012), the need for mentoring, feedback, and constructive criticism also indicates that individuals seek the environment that fits their needs (cf. Lievens \& Slaughter, 2016), whereas a less personal and friendly work environment (Bagley et al., 2012) seems to be 'accepted' even if it is unwanted. Therefore, it seems that the social categories 'small office auditors' and 'big office auditors' are characterized by different attributes. The prototypical 'big office auditor' seems to be a high-status individual motivated by monetary gain and career development, whereas the prototypical 'small office auditor' seems to be a low-status individual with lower career ambitions motivated by a friendly work environment (cf. Bagley et al., 2012).

The post-socialized narratives of who the auditor is may shed some light on the 'invisibility' of the audit firms as social groups. The traditional audit firm structure and the 'brand' of the firm are aspects connected directly to the audit firm. The traditional structure creates internal competition within the firm (cf. Stenger et al., 2017) and the 'brand' signals the organizational image and status. As competition, image and status were the weakest motivational drivers among audit staff (see paper III), the firm as a social group may not become salient, as these aspects are not internalized by audit staff and/or do not serve as positive distinctions within the audit arena (cf. Martin et al., 1983). An alternative interpretation is that due to (especially Big 4) audit firms being generally characterized by competition and status (cf. Stenger et al., 2017), competition and status are no longer needs and thus not motivational drivers as these needs are 'fulfilled' by the environment (Baumeister, 2016). Either way, audit firms seem to be nonsalient social groups as competition, status, and image 'characterize' the profession, therefore not being positive differentiating characteristics between social groups within the profession.

The audit profession is depicted as a stratified profession in the literature (cf. Abbott, 1988), as Big 4 firms are depicted as high-status firms providing superior audit quality in comparison to smaller audit firms (cf. e.g. DeAngelo, 1981) and serving high-status clients, i.e. listed and public interest companies, to a larger extent than other audit firms (cf. e.g. Carrington et al., 2013). However, as the audit firms do not seem to be salient bases for identification, this rather suggests a stratification of the profession on an office level (cf. paper III). The question is why office size serves as a basis for stratification. The answer seems to be found in the pre-socialized narrative of the audit arena. As smaller offices are associated with working in more rural areas and larger offices associated with working in big city areas, the 'small office auditor' is perceived as serving small owner-managed clients (or entrepreneurs) and the 'big office auditor' is perceived as serving public interest companies to a greater extent. However, as the 
Swedish audit market is dominated by small clients (cf. chapter 2), the SME client is the most prominent client category within the Swedish audit arena, which seemingly influences auditors' sense of identity to a greater extent than the public interest client category. Hence, the 'invisibility' of the audit firms as a social category could be explained by clients being a more salient basis for identification, creating similarities between firms, but differences between offices, as office size is associated with client size.

\subsection{Career progression and changes in narratives}

As paper III reports on differences between audit assistants and auditors and partners, this data provides some insights into how perceptions of the auditor social identity changes as the career progresses. The results indicate that as one progresses through the audit career, intrinsic drivers become more important motivational drivers. In other words, auditors and partners seem to be motivated by interesting work, contributing to the client, challenging work, and growth and learning to a greater extent than audit assistants (amongst other aspects - see paper III for more details). This suggests as one becomes more socialized into the profession, the more the auditor becomes a client oriented 'expert', who engages in varied and autonomous work, and who constantly needs to educate her/himself (cf. section 5.1.).

Auditors seem to become less reliant on mentoring and feedback and need less clarity and appreciation and recognition from immediate managers and colleagues than assistants, but this seems to change when one reaches the partner level, as the results indicate no differences between assistants and partners regarding social motivational drivers. Auditors and partners also seem to become more motivated by organizational image, status, competition, pride and achievement, with partners becoming less motivated by flexibility and work-life balance (see table 6 in paper III). As it has been argued that environments create and change needs (Baumeister, 2016), this may be viewed as a result of the socialization process within the audit profession, augmenting the idea of the high-status 'workaholic' auditor sustained by the profession and making auditors more 'streamlined' as the 'system' weeds out those not fitting or adapting to the social prototype (cf. Moreland et al., 2001; Stenger et al., 2017). In the words of Lupu \& Empson (2015, p. 1312), those who become auditors, and ultimately partners, are those "professionals who are most successful at playing the game", as "they have succeeded in internalizing the external structures.", meaning that they "are also most susceptible to being captured by [the game]" and thus, "also lose their ability to question the game and their investment in it". Learning and being 'caught up' by the game through the socialization within the up-or-out structure can thus explain differences in how assistants, auditors, and partners 
depict themselves, where the social identity of the auditor is mainly shaped by those on 'top' who are captured by the illusion of the audit arena having to function the way it does.

\subsection{Narratives told by former staff of auditors, audit firms and the audit profession}

The exit from the audit arena can be seen as a renunciation of a social identity, as exiting is a strategy for coping with a negative or unwanted social identity (cf. Tajfel \& Turner, 2004). The differences between former and current audit assistants' narratives on the audit arena could therefore be seen as indications of aspects of being an auditor that must be accepted by individuals in order to become an accepted part of the profession ${ }^{42}$.

The former audit assistants depicted the audit profession and the work environment to some extent similarly to current audit assistants (see paper IV). The former audit assistants experienced good relationships with colleagues and perceived the work of an audit assistant as involving career development, just as current audit assistants did (see table 2 in paper IV). Former assistants also saw the work as varied and associated the profession with societal benefits, just as current assistants did. Overall the work environment did not seem to be a reason for former audit assistants renouncing their social identities as auditors (see table 4 in paper IV). Hence, the narratives from the former assistants depict the auditors as a collegial individual who provides societal benefits and is driven by development.

Even though there were similarities between former and current audit staffs' narratives of the audit arena, in other respects, there were significant differences that seemed to influence the choice to exit the audit arena. Former assistants viewed audit work as involving lower worklife balance and lower degrees of flexibility in comparison to current assistants. The narrative of the auditor as overworked, stressed and busy depicted by the former audit assistant does not differ from the current assistants, as they also perceive the work to be stressful, however, this narrative seems to be stronger and more negative among those who have exited (cf. table 2 and 4 in paper IV). Former assistants perceived the audit profession as being less associated with sense of meaning, intellectual challenges, and career development than did current assistants

\footnotetext{
${ }^{42}$ Worthy of note, as being an official part of a group is not a requisite for identification with a social category, an exit from the audit arena does not necessarily mean that one denounces the social identity as an auditor. Research has shown that former audit employees can identify with the former audit employer (Iyer et al., 1997), and personal communication with former students that started in auditing but who left the profession indicates that former audit employees may also not leave the profession permanently, i.e. former employees may see it as an option to return to the audit firm.
} 
(see table 2 in paper IV). These data suggest that sense of meaning and intellectual challenges are aspects connected to the perceptions of the audit profession's status and prestige and the social benefits it provides (see table 3 in paper IV). So even though former and current audit assistants do not significantly differ in their perceptions of the status and prestige of the profession and the societal benefits it provides (cf. table 2 in paper IV), there seems to be differences in how status and societal benefits are viewed, and this influences the decision to exit the audit arena. The pre-socialized narratives of the audit arena may provide an answer to these different views ${ }^{43}$.

As chapter 4 suggests that sense of meaning is derived from contributing to the client, perceptions of the status of the profession and the societal benefits it provides may be dependent on what client type one associates the profession most with. As previous research (e.g. DeAngelo, 1981; Carrington et al., 2013) depicts public interest clients as high-status clients, those individuals who perceive the status of the profession being connected to "the guardian of the markets' benefits the profession provides may see the reality of the dominance of SME clients within the audit arena as an aspect lowering the status of the (Swedish) profession. Alternatively, those who perceive the societal benefits of the profession as contributing to small client growth and derive sense of meaning (and status) from working with these clients, might face internal restrictions regarding career development and status, if the firm culture stresses large clients as high status. Both types of mismatches might trigger an exit from the audit arena. Worthy of note, the quantitative survey data do not provide any direct evidence of the social groups 'small client/office auditor' and 'big client/office auditor'. However, the results indicating that perceptions of the profession influence exits from the audit arena (see paper IV), viewed in light of the pre-socialized perspective on the audit arena, suggest that there are two types of auditors with different views on professionalism and independence, and this can be a potential explanation for exits from the audit profession.

\footnotetext{
${ }^{43}$ Worthy of note again, the interviews in paper I and II were conducted with the partial aim to understand the findings in paper IV regarding the relationship between perceptions of the profession and employee turnover.
} 


\section{Chapter 6 - The narrative of the social identity audit arena}

This chapter discusses the analysis of pre-and post-socialized narratives of the social identity audit arena. This chapter also discusses the meanings of professionalism and independence given in the empirical narrative of the arena, with a particular focus on how independence and working in the public interest can be understood. The chapter also sums up the conclusions of the thesis, and discusses the theoretical, empirical, practical, and ethical implications of the results, as well as limitations and suggestions for future research. 


\subsection{The stratified audit arena}

The analysis suggests that the audit profession, the audit firms, and the accountees are 'invisible' social identities within the audit arena ${ }^{44}$. Therefore, these social groups seem to represent non-salient social identities within the audit arena. Even though the audit profession is 'invisible' in the pre- and post-socialized narratives of the audit arena, these narratives highlight the way in which the audit profession is to be understood. The main point of the combined narrative of the audit arena is that the profession seems to be a stratified profession (cf. paper II; Abbott, 1988), as there are two prominent social identities within the audit arena, which are related to two different types of accountors. The analysis suggests that the audit arena as presented in chapter 3 does not depict reality, as the audit arena is dominated by two social groups which I label the small client auditor, and the large (public) client auditor (see figure 5). Thus, this thesis provides an alternative 'picture' of the audit arena; a 'picture' heavily influenced by the interactions and contacts at the micro-level of the audit profession between auditors, audit teams, and offices and accountors.

This thesis highlights an 'unvoiced' narrative of the audit arena (cf. Durocher, Gendron, \& Picard, 2016). The current knowledge we have about the audit arena is heavily coloured by the Big 4' idea' of the profession as much of our knowledge of auditors is based on large client auditors (cf. Ramirez et al., 2015), who are predominately employed by the Big 4 audit firms (cf. Brivot et al., 2018; Causholli et al., 2019). The global (academic and audit profession) narrative of the audit arena is dominated by the idea of auditors serving the public interest. This narrative is predominately promoted by professional bodies and standard setters, but to some extent the Big 4 firm network (cf. e.g. Brouard et al., 2017; Cooper \& Robson, 2006). However, the SME accountor group is the largest client group among Swedish auditors (Carrington et al., $2019^{45}$ ) as it is in the profession at large (Ramirez et al., 2015). Hence, the global audit arena is dominated by small client auditors ${ }^{46}$. Consequently, the dominant public interest narrative is not representative of everyday practice for the majority within the profession (cf. Abbott, 1988; Durocher, Gendron, \& Picard, 2016). In other words, the global profession communicates the

\footnotetext{
${ }^{44}$ Potential explanations for the 'invisibility' of the audit firms are discussed in section 5.1., hence this chapter focuses on possible explanations for the 'invisible' profession and the 'invisible' accountees as social identities in section 6.3 .

${ }^{45}$ Approximately $64 \%$ of the auditors in this study reported that they predominately audit SMEs.

${ }^{46}$ However, small may have a different meaning in the Swedish context in comparison to other contexts due to the low limits of the mandatory audit (cf. chapter 2; Ramirez, 2009).
} 
profession's public interest service, i.e. auditors as the guardians of capital markets, whilst the majority of those working within the profession do not serve these clients. This thesis suggests that these practitioners are driven by another form of professionalism than 'guardians of the market' professionalism.

The analysis points to professionalism, i.e. the occupational and normative values guiding individuals within the profession (cf. Ackroyd, 2016; Evetts, 2011), being determined by the small client auditor, whose social identity seems heavily influenced by the small clients they serve (see (a) and (b) in figure 5). Small client professionalism seems to be rooted in the business perspective rather than the public service perspective (cf. figure 4 and 5), as adding value to the client seems to be the dominant value guiding audit work (cf. paper III). Professionalism from the traditional large client auditor perspective, i.e. 'guardians of the markets' professionalism, where the 'myth' of independence is crucial to uphold (Johed \& Catasús, 2018), is not prominent in the data, indicating a single dominant professional logic within the profession (cf. Alvehus, 2018; Broberg, 2013; Lokatt, 2018; see (b) in figure 5). In other words, the values associated with the small client auditor social identity seem to be more distinctive compared to the values associated with the large client auditor social identity and are therefore easier to identify with (cf. Ashforth \& Mael, 1989; chapter 3). The single dominant logic, i.e. a dominant meaning of professionalism, could thus be explained by these more distinctive values ${ }^{47}$. They seem to provide a more concrete identity foundation and may serve as a basis for integrating the social identities into one holistic (multifaceted) identity ${ }^{48}$ (cf. Ashforth et al., 2008; chapter 3; see (b) in figure 5).

Role (or identity) switching could cause role conflicts (i.e. conflicts between salient identities) ${ }^{49}$ among individual auditors if they serve different client types. Role switching may be a

\footnotetext{
${ }^{47}$ Small client auditor professionalism could also be a result of the training auditors receive in their early career. As large clients are few, it is likely that junior auditors are more involved in small client audits than large client audits, which may shape their views on professionalism in later career stages (cf. Sellers \& Fogarty, 2010).

${ }^{48}$ Auditors can however keep social identities separate from each other (cf. chapter 3).

${ }^{49}$ As the social identities within the audit arena seem to be tied to different work roles, conflicts between salient identities may be viewed as role conflicts. Both role conflicts and conflicts between salient identities stem from conflicting values being prescribed by the roles/identities. If identities/roles are kept separate, the individual may be able to act differently in these identities/roles and find it acceptable (i.e. one compartmentalises identities/roles and are thus able to 'handle' contradictory behaviour). If identities/roles are kept separate, individual auditors may therefore not experience conflicts, even if values are conflicting and result in contradictory behaviour. If
} 
mechanism through which auditors create the shared meaning of professionalism, regardless of whether the social identities of the small and large client auditor are kept separate or integrated. If auditors switch roles, they influence the professional narrative of both groups by 'transferring' ideas of what constitutes acceptable behaviour, values and attitudes for auditors, both intentionally and unintentionally (see section 3.2.). The larger the group is, the more intended and unintended influence may it have on what the shared professionalism constitutes (cf. Haslam \& Ellemers, 2005). The single dominant 'small client' professional logic could therefore possibly be 'enhanced' by auditors' role switching (see (c) in figure 5). However, the question remains whether large client auditors are guided by 'guardians of the market' professionalism, which Carrington et al. (2013) suggests, or whether there is one dominant professional logic guiding behaviour, as this thesis suggests. The question is also to what extent individual auditors serve different client types, i.e. to what extent auditors switch between the small client and large client roles (see (c) in figure 5).

\footnotetext{
identities/roles are integrated, contradicting values can be addresses through different strategies. Individuals may 'adapt' the enaction of the identity/role (i.e. adapt behaviour) in order to relieve discomforts (cf. Carrington \& Catasús, 2007), either by 'combining' the values in a way that make them less contradictory or by 'choosing' to act accordingly to the values which one 'prefers'. Individuals may also simply 'accept' the contradictory values and act according to the values prescribed by the identity/role, even if it causes discomforts (cf. Alvehus, 2018). Auditors may therefore 'accept', 'adapt' or 'reject' meanings of professionalism in different ways, depending on which social groups they identify with and in which ways, which in turn may or may not lead to (experienced) conflicts.
} 


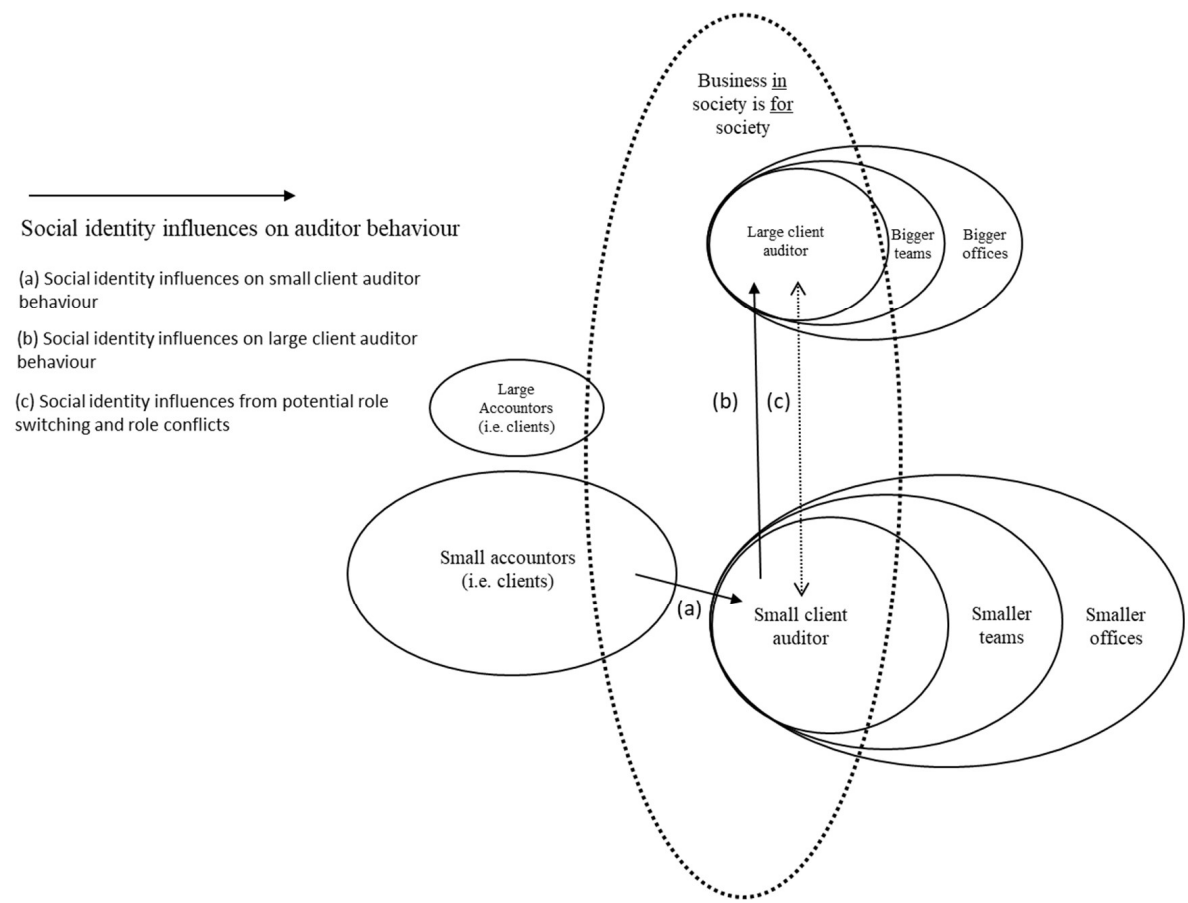

Figure 5: The narrated social identity arena - an alternative 'picture' of the audit profession

As literature often dichotomizes the audit profession in terms of Big 4 and Non-Big 4 firms, this thesis indicates that it may be an inappropriate way to dichotomize the profession, as the audit firm(s) networks are 'invisible' as social groups (cf. figure 5 and figure 4 in chapter 3). This notion is supported by a recently publish article (Carrington et al., 2019; also see Ramirez, 2009; Ramirez et al., 2015). Carrington et al. (2019, p. 1078) argued that "many recent changes concern auditors of specific types of clients rather than accounting firms as a whole" and that "professional educational programs are increasingly organized around certain types of clients. Hence, changes in these institutional arrangements may not be captured well by grouping accounting firms according to size (i.e., Big 4 vs. non-Big 4 firms).”. The authors thus argue for auditors serving the same type of accountors being more similar and different from auditors serving other types of accountors. Carrington et al. (2019, p. 1091) showed that accountor type "is relevant for explaining variation in conformity to professional values both within and between organizational contexts".

Carrington et al. (2019) thus supports the conclusion of this thesis that social groups within the audit arena are based on the accountors auditors serve (see figure 5), a grouping driven by an increased specialization of audit work. However, their results indicate that client commitment 
as a value has not become "an integral part of the profession", and that it is "the most contested value within the Swedish auditing profession." (Carrington et al., 2019, p. 1091). This is not a conclusion supported by the analysis in this thesis, as contributing to the client is a dominant theme of both the pre- and post-socialized narratives (cf. paper I and III). There are a few possible explanations for these divergent results. Firstly, Carrington et al. (2019) focuses on commitment $^{50}$ rather than identification and social identities (cf. Garcia-Faliéres \& Herrbach, 2015). Secondly, Carrington et al. (2019) data stem from 2010. As the more current presocialized and post-socialized narratives of the audit arena reported in this thesis are dominated by clients, it suggests a change potentially driven by the abolishment of the mandatory audit for small limited liability companies in 2010 (cf. Broberg et al., 2018).

The narrative of the social identity audit arena has implications for how professionalism and independence are to be understood, and the dominance of small client auditors may explain the 'invisibility' of the profession, the audit firms (see section 5.1. for this discussion) and the accountees as social identities. These aspects are further discussed in the next sections.

\subsection{Different perspective on professionalism and independence}

It is sometimes claimed that 'an audit is an audit is an audit' (cf. Brännström, 2018). Can one equivalently say: 'an auditor is an auditor is an auditor'? At the time of writing, a few days had passed after the deadline on comments on IAASBs discussion paper on Audits of Less Complex Entities. These comments point to disagreements regarding the need for audit standard for SMEs, however, they do point to audits in SMEs and larger clients being different and current audit standards being unsuitable for application to smaller clients (cf. IAASB, 2019; IAASB, n.d.; also see Durocher, Gendron \& Picard, 2016). Hence, an audit does not seem to be an audit, and this thesis indicates that an auditor is not an auditor. This has implications for how individuals are socialized into the profession, which role-conflicts emerge and what it is that influences inter-group relations within the profession (Ashforth \& Mael, 1989; cf. Durocher, Gendron \& Picard, 2016). In other words, these results have implications on how we can understand what the audit profession is and what professionalism constitutes within the audit

\footnotetext{
${ }^{50}$ Client commitment is measured through three statements in Carrington et al. (2019): (1) When someone praises my largest client, it feels like a personal compliment., (2) When I talk about my largest client, I usually say "we" rather than "they.", (3) The successes of my largest client are my successes. The data in this thesis does not touch upon client commitment in this sense.
} 
arena. How is independence and serving the public interest understood by auditors when it seems as if small client auditors and large client auditors work differently in their audits?

The small client auditor is perceived as a teacher and a 'consigliere' (see paper II), who helps the clients run their businesses better, and avoid problems with tax authorities et cetera, making it necessary for the auditor to have a good and close relationship with the client in order to fulfil her/his role (cf. Collin et al., 2017). The concept of independence must be given another meaning in order for the auditor to claim to be independent in fact and appearance in the relationship with these smaller clients, as reasonable and informed third parties could question independence in the traditional sense, i.e. independence in the light of the role auditors serve for public interest client firms. Working in the public interest can also be viewed from different perspectives, depending on whether one takes the view of the small or the large client auditor, as individual small clients do not have the same impact on society as public interest clients. The alternative views on independence and working for the public interest are discussed in more detail in the next paragraphs.

The small client auditor is arguably more dependent on the client for information about the audited entity, as smaller clients are often depicted as clients with low internal controls and documentation (Keasey et al., 1988; cf. IAASB, 2019), and 'bad' accounting as the management has little interest or knowledge of accounting (cf. Malmström, 2018). The need to satisfy small clients is also possibly higher to motivate the costs for these clients. Operational and organizational independence may thus be hard to achieve (cf. Keasey et al., 1988; Power, 1997), at least in appearance. However, as the separation of management and ownership is less of a problem in smaller clients, the notion of independence may not be an issue. Yet, lenders and tax authorities are important stakeholder for SMEs and the question is how they perceive the role of the auditor in these client firms. As the consigliere role of auditors for smaller clients has not been subject to public debate in Sweden, it seems as though the government and tax authorities accept auditors serving this role for these clients. The current debate has rather revolved around the decreased accounting quality in the smaller limited liability companies, indicating that the Swedish institutional stakeholders want auditors to serve this role for SMEs as it ensures accounting quality and may potentially lead to a greater possibility to detect economic crime. The lack of a debate on the consigliere role of auditors is not just restricted to the Swedish context, and this role seems to be generally accepted by European and American institutional stakeholders (Holmquist, 2001). 
One could however argue that the auditor is independent in relation to smaller clients, precisely due to the clients' lack of knowledge of accounting. If the client views the auditor as a consultant with expert knowledge, the auditor can be independent in fact, as being viewed as an expert allows the auditor to form conclusions based on professional judgment, and "act with integrity, and exercise objectivity and professional skepticism" (IESBA, 2018, p. 29), as the client places trust in the auditor's knowledge. However, independence in appearance is becoming more and more important in our increasingly 'anxious' society (Marténg, 2015).

Working in the public interest can alternatively be understood as auditors working to 'guard' both the local and the global society, not just the public interest as it is depicted in the audit standards (cf. Baker, 2005), as even small clients influence society. Smaller clients may be of particular importance in the local community, and collectively as large contributors to the general public, being the most common employers and contributors to the state treasury. Small client auditors may thus contribute to society by ensuring efficient businesses by being consiglieri, i.e. working with the management to ensure more efficient management, and in the long run survival, creating greater societal benefits, through better value creation, more job opportunities, and paid taxes. It is an alternative view of public interest than the 'traditional' view of auditors as monitors ensuring higher quality financial reports and decreasing information asymmetries when discussing public interest clients (cf. Collin et al., 2017). However, both views can be interpreted as "neo-liberal" or "liberal social democratic" views of public interest, where "the public interest is defined as maintaining the orderly functioning of commerce." (Baker, 2005, p. 694), which manifests itself within the social identity audit arena in the idea that 'business in society is for society' (see figure 5). The profession maybe ought to have a "critical social democratic perspective" on its duties, thus taking its political responsibility of being a party ensuring the betterment of the conditions for the marginalized and poor groups in society, in order to really serve the public interest (cf. Baker, 2005, p. 694; Humphrey, 2019).

The thesis suggests that views on professionalism differs between small client and large client auditors, bringing into the light the question of whether these auditors should be seen as belonging to the same profession. From a theoretical perspective, the different views of independence and working for the public interest, as implied by this thesis, are somewhat contradictory (cf. Baker, 2005). As the profession does not publicly discuss the different roles auditors have for different clients, nor discuss what working for the public interest means (cf. Dellaportas \& Davenport, 2008), the profession may be causing 'mismatches' between 
stakeholders' and the professions' perceptions of what auditing is, which potentially widens the expectation gap ${ }^{51}$. However, this also raises the question of what serving the public interest should mean, i.e. whether or not auditors should view the public interest as maintaining the orderly functioning of commerce, which both the small accountor and large accountor auditor perspectives on professionalism represent, or if auditors should take a greater responsibility for the function of society than just enabling commerce (cf. Humphrey, 2019).

\subsection{Explanations for the 'invisible' social groups}

An explanation for the invisibility of the profession in the pre- and post-socialized perceptions of the audit arena might be the 'discrepancy' between the global and local narratives of the profession. In other words, the perceptions of small client auditors and large client auditors might be created by the global Big 4 dominant narrative and the local national narratives of the profession (cf. Durocher, Gendron \& Picard, 2016). To clarify my point, I will use the Swedish context as an example.

Before the introduction of IFRS, the Swedish accounting and auditing profession widely debated (national) accounting standards, indicating a strong profession. However, as the Big 4 firms, when IFRS was introduced, increased their hold on the profession, the local profession seemed to lose its strength (cf. Brännström, 2018). The Big 4 firms, with their American influence and capital market 'neo-liberal' view, seemed to clash with the Swedish way of viewing work and business and the European, more stakeholder-oriented, 'liberal social democratic' view (cf. Abbott, 1988; Baker, 2005; Whittington, 2008; paper I and II). Maybe it is this shift in power that has resulted in a more stratified profession, as the national professions in general may have lost their strength (cf. Durocher, Gendron \& Picard, 2016). The bigger offices in the Big 4 firms may be more influenced by the global firm network, not only due to serving the large clients, but also due to being more strategically relevant parts of the local business for the global networks. The power thus seems to reside in a small portion of the local profession, which has motives to promote the narrative of the large client auditor (cf. Durocher, Gendron \& Picard, 2016). As local environments differ from the global environment (cf. chapter 2), the small client auditor narrative of professionalism may reflect a previously strong

\footnotetext{
${ }^{51}$ There were some indications in the comments on IESBAs discussion paper on auditing in Less Complex Entities, of perceptions of not having ISAs for SME audits increasing the expectation gap, as well as perceptions of dual standards increasing it. So, the profession seems to disagree to what extent 'an audit is an audit' and may thus disagree to which extent 'an auditor is an auditor'.
} 
local profession, possibly developed under a strong state as in Sweden. The portrayed 'guardians of the market' profession may therefore be invisible, as the majority of the practitioners do not identify with this global narrative (cf. Durocher, Gendron \& Picard, 2016; Ramirez, 2009). As the European countries, where the profession developed under a strong state (cf. Abbott, 1988) and where the business environment is generally stakeholder-oriented (cf. Whittington, 2008), share similarities with Sweden (cf. De Beelde, 2002), the findings may be generalizable to other similar audit arena contexts. However, the results also seem generalizable to the Anglo-Saxon context as Anglo-Saxon research also indicates differences between small client auditors and large client auditors (cf. Bagley et al., 2012; Brivot et al., 2018; Causholli et al., 2019; Durocher, Gendron \& Picard, 2016; Ramirez, 2009).

The 'invisibility' of the profession as a social actor may however be a result of the Swedish context (cf. Broberg, 2013). In Sweden, both the professional bodies, and the supervisory authority focus on the narrative of auditors as consiglieri (cf. Brännström, 2018; 2016). For example, the Swedish Inspectorate of Auditors, when arguing for the changes in competence demands for auditors, claimed that the main consequence for society of the change was that a broader recruitment base increases audit quality and "a greater opportunity for auditors to face new assignments in their profession and give economic added value to their customers" (Revisorsinspektionen, 2017, p. 22, my translation and emphasis). The Inspectorate, paradoxically, tells the same narrative as the profession, which suggests that the main purpose of the audit is the added economic value to the accountors rather than the independent assurance of financial statements to add value to the accountees. It is perhaps not surprising that the Inspectorate has adopted this view, as Per Johansson, the General Director of the Inspectorate who has initiated the changes, himself is a former (seemingly small client) auditor, socialized in one of the Big 4 firms (see his LinkedIn page).

The Swedish professional association FAR changed Secretary General recently, and the choice to appoint a non-auditor for the position was made (Fjällborg, 2019). As the former Secretary General Dan Brännström, who was a small client auditor (cf. Brännström, 2018), the appointment of Karin Apelman, with her experience from large organizations and being a board member of such, seems to indicate a shift from a small client to a large client perspective within the professional body (cf. Fjällborg, 2019). However, like her predecessor (cf. Brännström, 2018), Karin Apelman seem to see the main value of the audit to be added value to the client, as the contributions to society from the audit, are always secondary, as illustrated by her own words: "I am a warm advocate of auditing. Besides creating value and security for the individual 
company [i.e. the accountor], auditing is also socially useful" (Halling, 2018, my translation). As even the professional bodies and the Inspectorate of Swedish Auditors see the societal benefits of auditing as secondary and/or non-important, why should individual auditors view it differently? Hence, professionalism centres around clients, making both accountees and the profession non-salient basis for identification, and thus, invisible social actors.

\subsection{Main conclusions of the thesis}

This thesis contributes both to the substantive and conceptual theory used (see figure 6). The thesis contributes to the 'theory' of the audit arena through an alternative conceptualization of the audit arena. This alternative conceptualization highlights that the audit profession consists of two distinct groups of auditors. The 'dominant' ${ }^{52}$ meaning of professionalism for individuals within the audit arena seems to be 'created' by the largest group, the small client auditors ${ }^{53}$, seemingly making value-adding client service a core occupational and normative value guiding auditor behaviour. This professional narrative does not highlight independence (in the traditionally sense) as a normative value guiding professional behaviour; the narrative rather highlights a non-conflict between conducting business in society and conducting business for society. In other words, the respondents seem to express that the main function of the auditor is to provide the client with advice to develop the client business and it is this 'consulting' that benefits society, not the 'independent' assurance of financial reports, regardless of the size of the $\mathrm{client}^{54}$. If this is how the profession views serving the public interest, it suggests client

\footnotetext{
${ }^{52}$ By dominant meaning of professionalism, I mean that it is this meaning that is most frequent in the empirics and in the pre-socialized perspective, this meaning is 'present' in both the small client and large client context.

${ }^{53}$ Worthy of note; research seems to have depicted large client auditors as 'equally' focused on client -service as small client auditors (cf. e.g. Humphrey \& Moizer, 1990). Shareholders are not seen as the "primary clients; the CFO and the [accountor] are" (large client auditor quotation in Johed \& Catasús, 2018, p. 386). Hence, it might be the large client auditors that 'create' this professional narrative rather than the dominant small client auditor group (see section 6.1), if their values and norms are seen as more positively distinguishing e.g. due to them having a higher status within the profession than small client auditors (cf. chapter 3).

54 'True' independence is a 'myth', but large client auditors are assumed to have stronger incentives to portray an independent façade. Even if they do "sometimes act like proactive business consultants" (p. 369), they have to act in accordance with the "myth' that they are serving society by "supporting efficient capital markets" (Johed \& Catasús, 2018, p. 368). Hence, the independence façade may only be visible in so called 'front-stage acts', where the auditor faces the stakeholders who are most concerned by independence, namely the shareholders (Johed \& Catasús, 2018). The 'non-existence' of 'traditional' independence in the empirical narrative may therefore be a result of the focus on 'back-stage acts' or rather meanings behind the professional façade (cf. section 1.5.).
} 
identification not being an issue, as serving the clients' (and the audit firm's) business interests are arguably in society's best interest. The empirical contribution of the thesis is thus this alternative 'picture' of the audit arena, which highlights a different 'dichotomization' of the audit profession than the Big 4/Non-Big 4 dichotomy ${ }^{55}$.

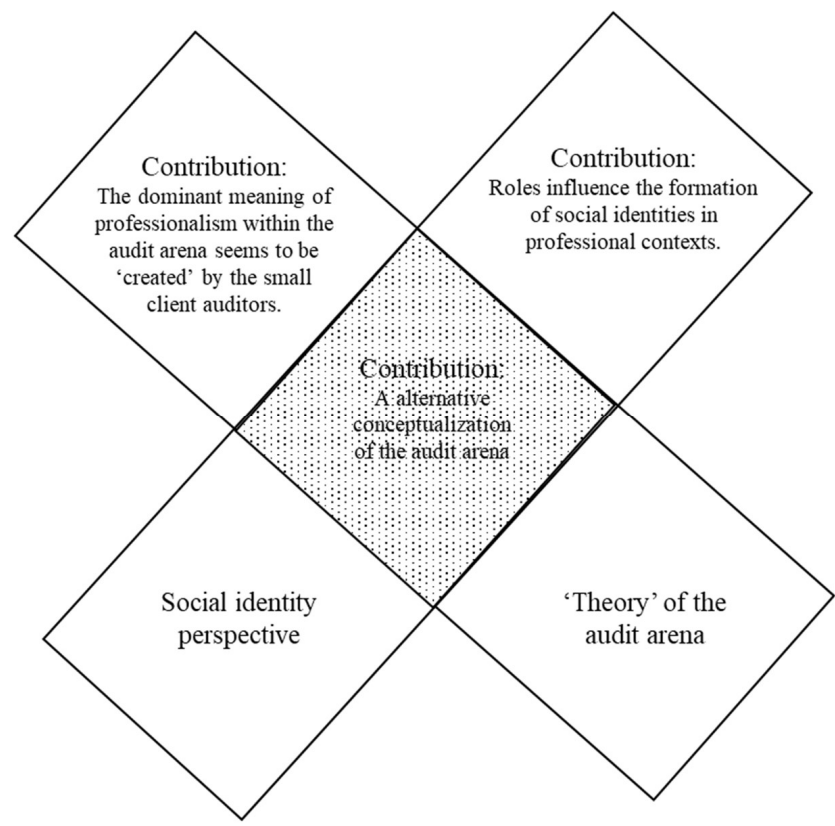

Figure 6: The thesis contributions to the substantive and conceptual theory

The holistic analysis contributes to social identity theory (SIT). Previously there has been a debate over the differences and similarities between SIT, which focuses on intergroup-relations, and identity theory, that focuses on roles and individual role-related behaviours (see Hogg et al., 1995; Stets \& Burke, 2000). The differences between the theories have been described as differences in level of analysis, as for example identity theory does not focus on cognitive processes as does SIT, and limits changes in identity to changes in role position (Hogg et al., 1995). Identity theory also does not focus on the role of out-groups in determining identity, but rather counter roles, which are only meaningful in clarifying meanings of role identities (Hogg et al., 1995). Others have argued for the theories being more similar than different, and differences being more "in terms of emphasis than kind" (Stets \& Burke, 2000, p. 234).

\footnotetext{
55 This alternative dichotomy is an empirical contribution of appended paper II.
} 
The holistic analysis suggests that roles play an important role in the formation of social identities, as being a professional is closely tied to the role one plays for one's clients. In other words, belonging to the social category 'the professional' incorporates both "who one is" and “what one does" (Stets \& Burke, 2000, p. 234: cf. chapter 4 and 5). As professions can be stratified, particularly by the type of clients the professional serves (cf. Abbott, 1988), the roles the professional serves represent both the internal structure of the profession and the out-groups that shape the in-group identity. In the audit arena, the roles of small and large client auditors do not just represent a stratification based on status, but they also serve as social categories providing individuals means to positively different themselves from others (Ashforth \& Mael, 1989; cf. Malmström, 2018; chapter 4 and 5). These social categories seem to particularly influence how one is socialized into the profession, as both this thesis, and previous research shows or indicates difference in perceptions of auditors, auditing, and professionalism among small client auditors and large client auditors (see Carrington et al., 2019; Collin et al., 2017; Gertsson, 2018; Malmström, 2018 for studies in the Swedish context; see Bagley et al., 2012; Brivot et al., 2018; Causholli et al., 2019; Durocher, Gendron \& Picard, 2016; Ramirez, 2009 for studies in the Anglo-Saxon context). The social identity theory perspective should thus be benefited by integrating role theory, especially in professional contexts, as role expectations seem to influence perceptions of social groups. The empirics therefore suggest an alternative perspective on the audit arena. The current audit literature highlights hybrid-identities or conflicting logics within the audit arena (cf. Alvehus, 2018; Broberg et al., 2018; Lokatt, 2018; Malsch \& Gendron, 2013: Picard, 2016), however, role conflicts may play a more important part in the day-to-day audit work. Previously the conflicting roles of being a professional auditor and a manager has been highlighted (cf. Broberg, 2013), whereas potentially conflicting roles for different clients has, to the best of my knowledge, not been considered in the audit context. An exploration of potential conflicting client-roles could provide new insight into audit-related behaviour and audit outcomes.

The empirical contributions of the individual appended papers are: (1) the dominant perception of the audit arena as an educational arena, suggesting that the profession upholds an educational professional jurisdiction, where the profession both teaches new generations of business leaders within the audit firms, and among their clients (see paper II), (2) the extent to which contributing to the client motivates audit staff in their work (see paper III), (3) contributing to the client seemingly being a more concrete understanding of the profession's societal benefit than working for the public interest (see paper I), and (4) exits from the profession being explained 
by having low perceptions of the profession (see paper IV). The results in appended paper IV show that perceptions of the profession's societal benefits, the sense of meaning and intellectual challenge derived from audit work, and career progression within the profession influences employee turnover. The findings in appended papers I, II, and III shed light on these results. They suggest that the audit firm structure (cf. paper I) as well as the client-dependent auditor role (cf. papers II and III) are potential causes of employee turnover. The audit firm structure creates an unresponsive environment, whereas Millennials seem to want responsive environments and the narrative of two auditors may create an expectancy gap between the profession and potential employees regarding the role of the auditor. Future studies on how the firm structure and client-specific auditor roles influence employee turnover could therefore provide us with a more elaborate understanding of who becomes and stays an auditor and why (cf. Raiborn \& Stern, 2019).

The narrative of two auditors could also be an explanation to the expectancy gap between the profession and the public regarding the role of the auditor. Audit standards for SMEs or less complex entities have been suggested to minimize the expectation gap between the profession and the public (cf. IAASB, 2019; IAASB, n.d.). If the narrative of two auditors is a cause for unmet expectations among potential employees, as paper IV seems to indicate, a potential solution to minimize the gap is to more clearly highlight the differences between small client auditors and large client auditors. One practical suggestion would be to return to the 'old' Swedish system of two titles and two authorizations. However, as the profession has been criticized for not serving its public interest, and this criticism mainly stemming from the accounting scandals in public interest firms, there might be an alternative solution to both the gap and the criticism. Having different principles (i.e. employers) responsible for the two types of auditors, i.e. the state for large client auditors and private firms for small client auditors, could clarify the role boundaries, and enhance the public interest duty of large client auditors ${ }^{56}$. However, as clients seem to be the most salient basis for identification, having large client auditors employed by the state would perhaps not make a difference. On the other hand, the state as an employer could impose different views on what the purpose of the audit is and transform the audit into something that serves a different kind of public interest than in the

\footnotetext{
56 This might however have negative effects on the attractiveness of being a large client auditor, as the public sector is often perceived as a less prestigeful employer by potential employees (this is based partly on the interviews for paper I and II, but also based on contact with students in general).
} 
present (cf. Raiborn \& Stern, 2019). As Humphrey (2019) suggest, maybe it is time to think differently about what auditing is and develop the audit into something more valuable for society, transforming auditing from a strict capital market 'empowerer' to a function that inherently changes the social inequalities of the world.

This thesis has several limitations. Even though the analysis suggests two types of auditors and different views on professionalism and independence, the empirics do not allow any conclusions to be drawn regarding the extent to which auditors (and other audit staff) in fact identify themselves with these social groups nor the extent to which these two social categories influence actual views on professionalism or independence. Future research should thus empirically explore these aspects and how identification with these social categories may influence auditor behaviour. As the bulk of the empirical material stems from a non-senior and non-top management perspective, more research on senior auditors' and partners' perceptions of the social identities in play within the audit arena is needed in order to validate the findings in this thesis. However, more research from the pre-socialized perspectives on the audit arena is also needed, as perceptions may change with experience. Future research should therefore longitudinally explore the extent to which and in which ways the perceptions of social categories within the audit arena change with experience, which also could provide insights into whether the narrative of two auditors influences job satisfaction and intentions and/or decisions to leave the profession.

\subsection{A personal reflection on the moral of the 'story'}

Teaching in business ethics as well as accounting and auditing, I cannot help but to reflect over the ethical implications of the thesis. As professional codes of ethics are a key characteristic of professions (cf. e.g. Abbott, 1988; Fogarty, 1992), the intentions, logics and principles that guide professionals are of importance. One reflection based on the pre-socialized perceptions of the audit arena is that students are heavily influenced by utilitarian thinking, i.e. to maximize the most good for the greatest number of parties, where the most important stakeholders whose good should be maximized are themselves and the firms they work for (cf. paper I; Dellaportas \& Davenport, 2008). The students therefore enter the audit arena with a highly 'profit-oriented' mindset. The commercially focused mindset among auditors may therefore not be 'created' by the socialization processes within the audit firms but by the higher education system. Academia must perhaps critically reflect upon what type of business leaders our education system fosters. Perhaps we can foster 'better' business leader, depending on who we want as business leaders. 
As paper I suggests, the hierarchical structure of the audit firms may be inappropriate in order to attract and retain potential employees. However, the audit firm structure also influences professional auditor ethics. The ethical codes of auditors (cf. Dellaportas \& Davenport, 2008), and business administration literature most often assumes that the best moral actions are determined from a utilitarian (i.e. cost benefit) analysis. However, there are many other ethical lenses through which professional ethics can be understood. The focus on utilitarianism and the hierarchical organizational structure within the audit arena creates a fertile ground for the creation of 'immoral robots' (cf. ten Bos, 1997). The structure in itself creates auditors with a certain professional morality. The client focus found in this thesis and the audit research on the commercialization of auditing (cf. e.g. Broberg et al., 2018; Picard, 2016) suggest that the audit arena, with profit-maximizing firms structured as up-or-out motivational systems, does not foster 'good ethical auditors' who care about the public interest, as the public interest is traditionally viewed (cf. paper I). The current structure of the audit labour market seems to create the 'non-interest' in the public interest as it fosters auditors to be business oriented.

The audit firm structure also 'brainwashes' individuals into accepting a subpar work environment and hinders individuals' critical thinking abilities (cf. Lupu \& Empson, 2015; also see paper I). It is paradoxical that the profession promotes itself as (and is seen by others as) a profession that can help others in becoming better and more efficient organizations, when it is incapable of solving its own problems ${ }^{57}$. The detrimental effects of the structure of the audit labour market has been known for some time, but as the system does not give current partners incentives to work towards changing it, nothing happens (see paper I for an elaborated discussion). The structure and the presence of differences between groups of auditors, as indicated by this thesis (also see Durocher, Gendron \& Picard, 2016), seem to "contribute to a host of socially and psychologically detrimental outcomes, precisely because it is so difficult to change the legitimacy and stability of social and organizational systems" (Hogg \& Terry, 2001, p. 188). Maybe it is time for society to 'help' the profession to solve its problems, by engaging in more multifaceted and elaborated discussions about more than what auditing is and could be (cf. Humphrey, 2019). We perhaps need to discuss what type of auditor ethics we want to guide audit work and what principles should guide the organization of audit work. Do we as a society want a profession that is depicted as a modern 'slave factory' (see Lupu \& Empson, 2015),

\footnotetext{
${ }^{57}$ This is a good example of the Swedish saying 'the cobbler's children walk in broken shoes'.
} 
where young workers (and senior staff), are worked to the bone, in promise of a slight chance of being rewarded financially? 


\section{References}

Abbasi, S. M., \& Hollman, K. W. (2000). Turnover: The Real Bottom Line. Public Personnel Management, 29(3), 333-342.

Abbott, A. (1988). The System of professions: An Essay on the Division of Expert Labor. Chicago: The University of Chicago Press.

Ackroyd, S. (2016). Sociological and organisational theories of professions and professionalism. In M. Dent, I. L. Bourgeault, J.-L. Denis, \& E. Kuhlmann (Eds.), The Routledge Companion to the Professions and Professionalism. Abingdon: Routledge. Retrieved from https://www.routledgehandbooks.com/doi/10.4324/9781315779447.ch1

Agevall, L., \& Jonnergård, K. (2013). Bilden av revisorn: Förändringar i beskrivningen av professionen 1989-2011 (En rapport från Forum för professionsforskning 2013:04) [The image of the auditor: Changes in the description of the profession 1989-2011]. Växjö: Linnéuniversitetet. Retrieved from http://lnu.divaportal.org/smash/get/diva2:664675/FULLTEXT01.pdf

Agevall, L., Jonnergård, K., \& Krantz, J. (2017). Frihet under ansvar eller ansvar under tillsyn? - Om dokumentstyrning av professioner [Freddom with responsibility or responsibility under supervision - About document management of professions]. Växjö: Linnaeus University Press.

Alvehus, J. (2006). Paragrafer och profit: om kunskapsarbetets oklarhet [Paragraphs and Profits: about the ambiguity of knowledge work]. Doctoral Dissertation, Lund University, School of Economics and Management.

Alvehus, J. (2018). Conflicting logics? The role of HRM in a professional service firm. Human Resource Management Journal, 28(1), 31-44.

Alvesson, M. (2000). Social Identity and the Problem of Loyalty in Knowledge-Intensive Companies. Journal of Management Studies, 37(8), 1101-1123.

Alvesson, M. (2001). Knowledge work: Ambiguity, image and identity. Human Relations, 54(7), 863-886.

Alvesson, M. (2011). Interpreting interviews. London: SAGE Publications Inc.

Alvesson, M., \& Robertson, M. (2016). Organizational identity: A Critique. In M. G. Pratt, M. Schultz, B. E. Ashforth, \& D. Ravasi (Eds.), The Oxford Handbook of Organizational Identity (pp. 160-182). Oxford: Oxford University Press.

Alvesson, M., \& Sköldberg, K. (2009). Reflexive Methodology: New Vistas for Qualitative Research (Vol. 2). London: SAGE Publications Inc.

Anderson, H. J., Baur, J. E., Griffith, J. A., \& Buckley, M. R. (2017). What works for you may not work for (Gen)Me: Limitations of present leadership theories for the new generation. The Leadership Quarterly, 28(1), 245-260.

Anderson-Gough, F., Grey, C., \& Robson, K. (1998). Making Up Accountants: The organizational and professional socialization of trainee chartered accountants. Aldershot: Ashgate Publishing Ltd.

Anderson-Gough, F., Grey, C., \& Robson, K. (2000). In the Name of the Client: The Service Ethic in Two Professional Services Firms. Human Relations, 53(9), 1151-1174.

Anderson-Gough, F., Grey, C., \& Robson, K. (2001). Tests of time: organizational timereckoning and the making of accountants in two multi-national accounting firms. Accounting, Organizations and Society, 26(2), 99-122.

Anderson-Gough, F., Grey, C., \& Robson, K. (2002). Accounting professionals and the accounting profession: linking conduct and context. Accounting and Business Research, $32(1), 41-56$. 
Ashforth, B. E., \& Johnson, S. A. (2001/2012). Which Hat to Wear? The Relative Salience of Multiple Identities in Organizational Contexts. In M. A. Hogg, \& D. J. Terry (Eds.), Social identity processes in organizational contexts (pp. 31-48). Binghamton, NY: The Haworth Press (Edition cited here is New York, NY: Psychology Press).

Ashforth, B. E., \& Mael, F. (1989). Social Identity Theory and the Organization. The Academy of Management Review, 14(1), 20-39.

Ashforth, B. E., Harrison, S. H., \& Corley, K. G. (2008). Identification in Organizations: An Examination of Four Fundamental Questions. Journal of Management, 34(3), 325-374.

Ashforth, B. E., Rogers, K. M., \& Corley, K. G. (2011). Identity in Organizations: Exploring Cross-Level Dynamics. Organization Science, 22(5), 1144-1156.

Bagley, P. L., Dalton, D., \& Ortegre, M. (2012). The Factors that Affect Accountants' Decisions to Seek Careers with Big 4 versus Non-Big 4 Accounting Firms. Accounting Horizons, 26(2), 239-264.

Baker, C. R. (2005). What is the meaning of "the public interest"? Examining the ideology of the American public accounting profession. Accounting, Auditing \& Accountability Journal, 18(5), 690-703.

Bamber, E. M., \& Iyer, V. M. (2002). Big 5 Auditors' Professional and Organizational Identification: Consistency or Conflict? Auditing: A Journal of Practice \& Theory, 21(2), 21-38.

Bamber, E. M., \& Iyer, V. M. (2007). Auditors' Identification with Their Clients and Its Effect on Auditors' Objectivity. Auditing: A Journal of Practice and Theory, 26(2), 1-24.

Bamber, M., \& Iyer, V. (2009). The effect of auditing firm's tone at the top on auditors' job autonomy, organizational-professional conflict, and job satisfaction. International Journal of Accounting, 17(2), 136-150.

Barney, J. (1991). Firm Resources and Sustainable Competitive Advantage. Journal of Management, 17(1), 99-120.

Baumeister, R. F. (2016). Towards a general theory of motivation: Problems, challenges, opportunities, and the big picture. Motivation and Emotion, 40(1), 1-10.

Beech, N. (2011). Liminality and the practices of identity reconstruction. Human Relations, 64(2), 285-302.

Benke, R. L., \& Rhode, G. R. (1980). The job satisfaction of higher level employees in large certified public accounting firms. Accounting, Organizations and Society, 5(2), 187201.

Bévort, F. (2012). Making sense of management with logics: An ethnographic study of accountants who become managers. Doctoral Dissertation, Copenhagen Business School.

Bévort, F., \& Suddaby, R. (2016). Scripting professional identities: how individuals make sense of contradictory institutional logics. Journal of Professions and Organization, 3(1), 17 38. doi:10.1093/jpo/jov007

Borg, E. (2014). Liminality at Work: Mobile Project Workers In-Between. Doctoral Dissertation, Linköping University, Department of Management and Engineering.

Brante, T. (1988). Sociological approaches to the professions. Acta Sociologica, 31(2), 119142.

Braun, V., \& Clarke, V. (2006). Using thematic analysis in psychology. Qualitative Research in Psychology, 3(2), 77-101.

Brewer, M. B. (1999). Multiple identities and identity transition: Implications for Hong Kong. International Journal of Intercultural Relations, 23(2), 187-197.

Brien, A. (1998). Professional Ethics and The Culture of Trust. Journal of Business Ethics, 17(4), 391-409. 
Brivot, M., Roussy, M., \& Mayer, M. (2018). Conventions of Audit Quality: The Perspective of Public and Private Company Audit Partners. Auditing: A Journal of Practice \& Theory, 37(2), 51-71.

Broberg, P. (2013). The auditor at work: A study of auditor practice in Big 4 audit firms. Doctoral Dissertation, Lund University, School of Economics and Management.

Broberg, P., \& Tagesson, T. (2017). Magisterexamen viktig för revisorsyrkets status [Master's degree important for the status of the audit occupation]. Retrieved 04 29, 2019, from Tidningen Balans: https://www.tidningenbalans.se/debatt/magisterexamen-viktig-forrevisorsyrkets-status/

Broberg, P., Umans, T., Skog, P., \& Theodorsson, E. (2018). Auditors' professional and organizational identities and commercialization in audit firms. Accounting, Auditing \& Accountability Journal, 31(2), 374-399.

Brouard, F., Bujaki, M., Durocher, S., \& Neilson, L. C. (2017). Professional Accountants' Identity Formation: An Integrative Framework. Journal of Business Ethics, 142(2), $225-238$.

Brown, V. L., Gissel, J. L., \& Neel, D. G. (2016). Audit quality indicators: perceptions of juniorlevel auditors. Managerial Auditing Journal, 31(8/9), 949-980.

Brännström, D. (2016). Är intimitet din framgångsformel? [Is intimacy your formula for success?]. Tidningen Balans(9), p. 3.

Brännström, D. (2018). Mitt liv som FAR [My life as FAR]. Stockholm: BAS ekonomisk förening.

Burrowes, A., \& Persson, M. (2000). The Swedish management audit: a precedent for performance and value for money audits. Managerial Auditing Journal, 15(3), 85-97.

Cable, D. M., \& Judge, T. A. (1996). Person-Organization Fit, Job Choice Decisions, and Organizational Entry. Organizational Behaviour and Human Decision Processes, 67(3), 294-311.

Callius, S. (2018). Regeringen säger nej till återinförd revisionsplikt [The Government says no to reinstated mandatory audit]. Retrieved 07 26, 2019, from Civilekonomen: https://www.civilekonomen.se/aktuellt/regeringen-sager-nej-till-aterinfordrevisionsplikt/

Carrington, T. (2010). Revision [Auditing]. Malmö: Liber AB.

Carrington, T. (2014). Revision [Auditing] (2 ed.). Stockholm: Liber.

Carrington, T., \& Catasús, B. (2007). Auditing Stories about Discomfort: Becoming Comfortable with Comfort Theory. European Accounting Review, 16(1), 35-58.

Carrington, T., Johansson, T., Johed, G., \& Öhman, P. (2013). An Empirical Test of the Hierarchical Construct of Professionalism and Managerialism in the Accounting Profession. Behavioral Research in Accounting, 25(2), 1-20.

Carrington, T., Johansson, T., Johed, G., \& Öhman, P. (2019). The Client as a Source of Institutional Conformity for Commitments to Core Values in the Auditing Profession. Contemporary Accounting Research, 36(2), 1077-1097.

Carr-Saunders, A. M., \& Wilson, P. A. (1933). The Professions. Oxford: Oxford University Press.

Carter, C., \& Spence, C. (2014). Being a Successful Professional: An Exploration of Who Makes Partner in the Big 4. Contemporary Accounting Research, 31(4), 949-981.

Causholli, M., Hux, C. T., \& Zimmerman, A. B. (2019). Accounting Firm Size and Culture: An Institutional Theory Perspective from Non-Big 4 Partners with Big 4 Experience. Paper presented at the 10th EARNet symposium in Parma, Italy.

Cennamo, L., \& Gardner, D. (2008). Generational differences in work values, outcomes and person-organisation value fit. Journal of Managerial Psychology, 23(8), 891-906. 
Chatman, J. A. (1991). Matching People and Organizations: Selection and Socialization in Public Accounting Firms. Administrative Science Quarterly, 36(3), 459-484.

Civilekonomerna. (n.d.). De tio vanligaste frågorna [The ten most common questions]. Retrieved 05 01, 2019, from Civilekonomerna: https://civilekonomerna.se/de-tiovanligaste-fragorna

Client. (2019). Retrieved 10 08, 2019, from Merriam-Webster.com: https://www.merriamwebster.com/dictionary/client\#other-words

Coffey, A. (1994). Timing is everything: Graduate accountants, time and organizational commitment. Sociology, 28(4), 943-956.

Collin, S.-O. Y., Ahlberg, J., Berg, K., Broberg, P., \& Karlsson, A. (2017). The auditor as consigliere in family firm. Journal of Family Business Management, 7(1), 2-20.

Cooper, D. J., \& Robson, K. (2006). Accounting, professions and regulation: Locating the sites of professionalization. Accounting, Organizations and Society, 31(4), 415-444.

Corporate Finance Institute. (n.d.). Big Four Accounting Salary: An overview of accounting compensation at the Big Four. Retrieved 05 01, 2019, from Corporate Finance Institute: https://corporatefinanceinstitute.com/resources/careers/compensation/big-fouraccounting-salary/

Covaleski, M. A., Dirsmith, M. W., Heian, J. B., \& Samuel, S. (1998). The Calculated and the Avowed: Techniques of Discipline and Struggles over Identity in Big Six Public Accounting Firms. Administrative Science Quarterly, 43(2), 293-327.

Creswell, J. W. (2014). Research design: Qualitative, Quantitative and Mixed Method Approaches (4 ed.). Thousand Oaks: Sage Publications Inc.

Dalton, D. R., \& Todor, W. D. (1979). Turnover Turned over: An Expanded and Positive Perspective. The Academy of Management Review, 4(2), 225-235.

De Beelde, I. (2002). Creating a profession 'out of nothing'? The case of the Belgian auditing profession. Accounting, Organizations and Society, 27(4-5), 447-470.

DeAngelo, L. E. (1981). Auditor size and Audit Quality. Journal of Accounting and Economics, 3(3), 183-199.

Dellaportas, S., \& Davenport, L. (2008). Reflections on the public interest in accounting. Critical Perspectives on Accounting, 19(7), 1080-1098.

Donovan, S., O'Sullivan, M., \& Doyle, E. J. (2016). Employee voice and silence in auditing firms. Employee Relations, 38(4), 563-577.

Durocher, S., Bujaki, M., \& Brouard, F. (2016). Attracting Millennials: Legitimacy management and bottom-up socialization processes within accounting. Critical Perspectives on Accounting, 39(September), 1-24.

Durocher, S., Gendron, Y., \& Picard, C.-F. (2016). Waves of Global Standardization: Small Practitioners' Resilience and Intra-Professional Fragmentation within the Accounting Profession. Auditing: A Journal of Practice \& Theory, 35(1), 65-68.

Ekelund, B., \& Stepien, E. (2016). Revisorn - en medveten social konstruktion: en studie om hur revisorer aktivt arbetar för att påverka den stereotypa bild som finns av dem [The auditor - a conscious social construction: A study on how auditors actively work to influence the stereotype]. Master Dissertation, Linköping University, Department of Management and Engineering.

Elliott, E. S., \& Dweck, C. S. (1988). Goals: An approach to motivation and achievement. Journal of Personality and Social Psychology, 54(1): 5-12.

Eskildsen, J. K., Kristensen, K., \& Westlund, A. H. (2004). Work motivation and job satisfaction in the Nordic countries. Employee relations, 26(2), 122-136.

Evetts, J. (2011). Sociological Analysis of Professionalism: Past, Present and Future. Comparative Sociology, 10(1), 1-37. 
FAR. (2017). FAR och Srf konsulterna avslutar samarbetet [FAR and Srf konsulterna end their collaboration]. Retrieved 04 29, 2019, from FAR.se: https://www.far.se/nyheter/2017/augusti/far-och-srf-konsulterna-avslutar-samarbetet/

FAR. (n.d). Hur blir jag auktoriserad redovisningskonsult? [How do I become a authorized accounting consultant?]. Retrieved 04 30, 2019, from FAR: https://www.far.se/medlemskategorier/redovisningskonsult/hur-blir-jag-auktoriseradredovisningskonsult/

Fjällborg, U. (2019). Så ska Karin Apelman göra om FAR [This is how Karin Apelman will change FAR]. Retrieved 03 09, 2019, from Realtid.se: https://www.realtid.se/karriar/saska-karin-apelman-gora-om-far

Fogarty, T. J. (1992). Organizational Socialization in Accounting Firms: A Theoretical Framework and Agenda for Future Research. Accounting Organizations and Society, 17(2), 129-149.

Friedson, E. (1989). Theory and the Professions. Indiana Law Journal, 64(3), 423-432. Retrieved from https://www.repository.law.indiana.edu/ilj/vol64/iss3/1

Garcia-Faliéres, A., \& Herrbach, O. (2015). Organizational and Professional Identification in Audit Firms: An Affective Approach. Journal of Business Ethics, 132(4), 753-763.

Gendron, Y., \& Suddaby, R. (2004). Professional insecurity and the erosion of accountancy's jurisdictional boundaries. Canadian Accounting Perspectives, 3(1), 85-115.

George, J., \& Wallio, S. (2017). Organizational justice and millennial turnover in public accounting. Employee Relations, 39(1), 112-126.

Gertsson, N. (2018). Exploring the concept of added value from an auditor's perspective. Working paper, Department of Management and Engineering, Linköping University, 18 December.

Gertsson, N., Sylvander, J., Broberg, P., \& Friberg, J. (2016). Exploring Auditor Motivation and Job Satisfaction- A Study focusing on Generation Y. Paper presented at the 39th European Accounting Association Annual Congress in Maastricht, Netherlands.

Gertsson, N., Sylvander, J., Broberg, P., \& Friberg, J. (2017). Exploring audit assistants' decision to leave the audit profession. Managerial Auditing Journal, 32(9), 879-898.

Goffman, E. (1959/1990). The Presentation of Self in Everyday Life. Garden City, NY: Anchor Books (Edition cited here is London, UK: Penguin Books Ltd).

Grey, C. (1998). On being a professional in a "Big six" firm. Accounting, Organizations and Society, 23(5/6), 569-587.

Guénin-Paracini, H., Malsch, B., \& Tremblay, M.-S. (2015). On the Operational Reality of Auditors' Independence: Lessons from the Field. Auditing: A Journal of Practice \& Theory, 34(2), 201-236.

Guo, K. H. (2018). The odyssey of becoming: Professional identity and insecurity in the Canadian accounting field. Critical Perspectives on Accounting, 56, 20-45.

Guyader, H. (2019). The Heart \& Wallet Paradox of Collaborative Consumption. Doctoral Dissertation, Linköping University, Faculty of Arts and Sciences

Hadjipetri Glantz, S. (2017). Risk för byråbubblor med ny revisorsutbildning [Risk for firmbubbles with new auditor education]. Retrieved 04 29, 2019, from Tidningen Balans: https://www.tidningenbalans.se/nyheter/risk-for-byrabubblor-med-nyrevisorsutbildning/

Hadjipetri Glantz, S. (2019-a). Timkravet för revisorer avskaffas [Hour-requirements abolished for auditors]. Retrieved 07 23, 2019, from Tidningen Balans: https:/www.tidningenbalans.se/nyheter/timkravet-for-revisorer-avskaffas/

Hadjipetri Glantz, S. (2019-b). Höga löner i branschen - men inte för nyutexaminerade [High salaries in the industry - but not for newly graduated]. Retrieved 0306,2019 , from 
Tidningen Balans: https://www.tidningenbalans.se/nyheter/hoga-loner-i-branschenmen-inte-for-nyutexaminerade/

Halling, P. (2018). Karin Apelman: "Att komma utifrån är en styrka" [Karin Apelman: "To come from outside [of the profession] is a strenght"]. Retrieved 09 24, 2019, from Tidningen Balans: https://www.tidningenbalans.se/nyheter/karin-apelman-att-kommautifran-ar-en-styrka/

Hanlon, G. (1996). 'Casino Capitalism' and the Rise of the 'Commercialised' Service ClassAn Exploration of the Accountant. Critical Perspectives on Accounting, 7(3), 339-363.

Haslam, S. A., \& Ellemers, N. (2005). Social Identity in Industrial and Organizational Psychology: Concepts, Controversies, and Contributions. In G. P. Hodgkinson, \& J. K. Ford (Eds.), International Review of Industrial and Organizational Psychology Volume 20 (pp. 39-118). Chichester: John Wiley \& Sons Ltd.

Haslam, S. A., Powell, C., \& Turner, J. C. (2000). Social Identity, Self-categorization, and Work Motivation: Rethinking the Contribution of the Group to Positive and Sustainable Organisational Outcomes. Applied Psychology: An International Review, 49(3), 319339.

Heck, R. H. (1995). Organizational and Professional Socialization: Its Impact on the Performance of New Administrators. The Urban Review, 27(1), 31-49.

Hedström, P., \& Ylikoski, P. (2010). Causal Mechanisms in the Social Sciences. The Annual Review of Sociology, 36, 49-67.

Herrbach, O. (2001). Audit quality, auditor behaviour and the psychological contract. The European Accounting Review, 10(4), 787-802.

Herbohn, K. (2004). Informal mentoring relationships and the career processes of public accountants. The British Accounting Review, 36(4), 369-393.

Herbohn, K. (2005). Job satisfaction dimensions in public accounting practice. Accounting Research Journal, 18(2), 63-82.

Hess, N., \& Jepsen, D. M. (2009). Career stage and generational differences in psychological contracts. Career Development International, 14(3), 261-283.

Hogg, M. A., \& Terry, D. J. (2001). Social Identity Theory and Organizational Processes. In M. A. Hogg, \& D. J. Terry (Eds.), Social Identity Processes in Organizational Contexts (pp. 1-12). Binghamton, NY: The Haworth Press (Edition cited here is New York, NY: Psychology Press).

Hogg, M. A., Terry, D. J., \& White, K. M. (1995). A Tale of Two Theories: A Critical Comparison of Identity Theory with Social Identity Theory. Social Psychology Quarterly, 58(4), 255-269.

Holmquist, B. (2001). Göran Tidström: "Frågan om revisorns oberoende är i ett vidare perspektiv inte något stort ämne i den internationella debatten" [The question of auditor independence is in a broader perspective not a big topic in the international debate]. Tidningen Balans, 11. Retrieved from faronline.se

Hornsey, M. J. (2008). Social Identity Theory and Self-categorization Theory: A Historical Review. Social and Personality Psychology Compass, 2(1), 204-222.

Hudaib, M., \& Haniffa, R. (2009). Exploring auditor independence: an interpretive approach. Accounting, Auditing \& Accountability Journal, 22(2), 221-246.

Humphrey, C. (2019). Thinking differently is 'audit'. Retrieved 09 24, 2019, from AuditFutures: https://auditfutures.net/blogs/thinking-differently-is-audit

Humphrey, C., \& Loft, A. (2006). Organising a Worldwide Accountancy Profession with the help of a Website: IFAC.ORG. Paper presented at The 8th interdisciplinary Perspectives on Accounting Conference, IPA.

Humphrey, C., \& Moizer, P. (1990). From techniques to ideologies: An alternative perspective on the audit function. Critical Perspectives on Accounting, 1(3), 217-238. 
IAASB. (2019). Audits of Less Complex Entities: Exploring Possible Options to Address the Challenges in Applying the ISAs [Discussion paper]. New York: IAASB. Retrieved from http://www.ifac.org/publications-resources/discussion-paper-audits-lesscomplex-entities

IAASB. (n.d.). Discussion paper, audits of less complex entities: Exploring Possible Options to Address the Challenges in Applying the ISAs. Retrieved 10 28, 2019, from IAASB: https://www.iaasb.org/publications-resources/discussion-paper-audits-less-complexentities

IASB. (2018). Conceptual Framework for Financial Reporting. Retrieved from IFRS.org: https://www.ifrs.org/projects/2018/conceptual-framework/\#published-documents

Ibarra, H. (1999). Provisional selves: Experimenting with Image and Identity in Professional Adaptation. Administrative Science Quarterly, 44(4), 764-791.

IESBA. (2018). Handbook of the International Code of Ethics for Professional Accountants. Retrieved from International Ethics Standards Board for Accountants: https://www.ethicsboard.org/system/files/publications/files/IESBA-Handbook-Codeof-Ethics-2018.pdf

IFAC. (n.d.). Member Organizations and Country Profiles. Retrieved 03 26, 19, from IFAC: https://www.ifac.org/about-ifac/membership/member-organizations-and-countryprofiles

Ihantola, E.-M., \& Kihn, L.-A. (2011). Threats to validity and reliability in mixed methods accounting research. Qualitative Research in Accounting and Management, 8(1), 3958.

Ijiri, Y. (1983). On the accountability-based conceptual framework of accounting. Journal of Accounting and Public Policy, 2(2), 75-81.

Isaksson, K., Bernhard, C., Claes, R., De Witte, H., Guest, D., Krausz, M., . . Schalk, R. (2003). Employment contracts and psychological contracts in Europe: Results from a pilot study (Saltsa report 2003:1). Stockholm: National Institute for Working Life \& SALTSA 2003.

Iyer, V. M., Bamber, E. M., \& Barefield, R. M. (1997). Identification of Accounting Firm Alumni with Their Former Firm: Antecedents and Outcomes. Accounting, Organizations and Society, 22(3/4), 315-336.

Jeacle, I. (2008). Beyond the boring grey: The construction of the colourful accountant. Critical Perspectives on Accounting, 19(8), 1296-1320.

Jenkins, R. (2008). Social Identity (3 ed.). Abingdon: Routledge.

Jeppesen, K. K. (1998). Reinventing auditing, redefining consulting and independence. European Accounting Review, 7(3), 517-539.

Johansson, P. (2017). Revisorsyrket måste bli mer attraktivt. Retrieved 04 29, 2019, from Tidningen Balans: https://www.tidningenbalans.se/debatt/revisorsyrket-maste-bli-merattraktivt/

Johed, G., \& Catasús, B. (2018). Auditor Face-Work at the Annual General Meeting. Contemporary Accounting Research, 35(1), 365-393.

Johnson, J. M., \& Ng, E. S. (2016). Money Talks or Millennials Walk: The Effect of Compensation on Nonprofit Millennial Workers Sector-Switching Intentions. Review of Public Personnel Administration, 36(3), 283-305.

Johnson, R. B., Onwuegbuzie, A. J., \& Turner, L. A. (2007). Toward a Definition of Mixed Methods Research. Journal of Mixed Methods Research, 1(2), 112-133.

Jost, J. T., \& Elsbach, K. D. (2001/2012). How Status and Power Differences Erode Personal and Social Identities at Work: A System Justification Critique of Organizational Applications of Social Identity Theory. In M. A. Hogg, \& D. J. Terry (Eds.), Social 
Identity Processes in Organizational Contexts (pp. 181-196). Binghamton, NY: The Haworth Press (Edition cited here is New York, NY: Psychology Press).

Keasey, K., Watson, R., \& Wynarczyk, P. (1988). The Small Company Audit Qualification: A Preliminary Investigation. Accounting and Business Research, 18(72), 323-334.

Kornberger, M., Justesen, L., \& Mouritsen, J. (2011). "When you make manager, we put a big mountain in front of you": An ethnography of managers in a Big 4 Accounting Firm. Accounting, Organizations and Society, 36(8), 514 - 533.

Kouakou, D., Boiral, O., \& Gendron, Y. (2013). ISO auditing and the construction of trust in auditor independence. Accounting, Auditing \& Accountability Journal, 26(8), 12791305.

KPMG. (2019). Arsredovisning 2017/2018 [Annual report 2017/2018]. Retrieved from KPMG: $\quad$ https://assets.kpmg/content/dam/kpmg/se/pdf/komm/2019/KPMGArsredovisning-2018.pdf

Kreiner, G. E., Hollensbe, E. C., \& Sheep, M. L. (2006). On the edge of identity: Boundary dynamics at the interface of individual and organizational identities. Human Relations, 59(10), 1315-1341.

Lagnehag Zars, P. (2017). Srf konsulterna och FAR [Srf konsulterna and FAR]. Retrieved 04 29, 2019, from Tidningen Konsulten: https://www.tidningenkonsulten.se/artiklar/srfkonsulterna-och-far-bryter-samarbetet/

Laird, M. D., Harvey, P., \& Lancaster, J. (2015). Accountability, entitlement, tenure, and satisfaction in Generation Y. Journal of Managerial Psychology, 30(1), 87-100.

Larsson, R. (1990). Coordination of Action in mergers and Acqusitions: Intepretive and Systems Approaches towards Synergy. Doctoral Dissertation, Lund University, Department of Business Administration.

Ledarna. (n.d.). Uppsägning - rättigheter och skyldigheter [Termination of employment - rights and obligations]. Retrieved 05 01, 2019, from Ledarna: https:/www.ledarna.se/stod-ichefsrollen/arbetsratt/uppsagning-rattigheter-och-skyldigheter/

Lennartsson, R. (2018). Up or out - vart leder det oss? [Up-or-out -where does it lead us?]. Tidningen Balans(1), pp. 19-22.

Lievens, F., \& Slaughter, J. E. (2016). Employer Image and Employer Branding: What We Know and What We Need to Know. Annual Review of Organizational Psychology and Organizational Behavior, 3, 407-440.

Lokatt, C. (2018). Auditors' Construction of Performance: a study on the duality of performance in the auditing profession. Doctoral dissertation, Stockholm University, Stockholm Business School.

Lupu, I., \& Empson, L. (2015). Illusio and overwork: playing the game in the accounting field. Accounting, Auditing \& Accountability Journal, 28(8), 1310-1340.

Malmström, E. (2018). It's all about the game board: On auditors' appearance and expertise. Presented at the 2017 Critical Perspectives on Accounting Conference, CPA, Québec City, Canada, 3-5 July 2017. Also presented at the colloquium of the 12th Interdisciplinary Perspectives on Accounting Conference, IPA, held at the University $\begin{array}{llll}\text { of Edinburgh } & \text { B. } & \text { Retrieved } & \text { from }\end{array}$ portal.org/smash/get/diva2:1280231/FULLTEXT01.pdf

Malsch, B., \& Gendron, Y. (2013). Re-Theorizing Change: Institutional Experimentation and the Struggle for Domination in the Field of Public Accounting. Journal of Management Studies, 50(5), 870-899.

Marténg, C. (2015). "I ett ängsligt samhälle är det viktigt att allt ser rätt ut" - revisorerna har inte hängt med ["In an anxious society it is important that everything looks right" auditors have not kept up]. Tidningen Balans(6), pp. 16-18. 
Martin, C. A. (2005). From high maintenance to high productivity: What managers need to know about Generation Y. Industrial and Commercial Training, 37(1), 39-44.

Martin, J., Feldman, M. S., Hatch, M., \& Sitkin, S. B. (1983). The Uniqueness Paradox in Organizational stories. Administrative Science Quarterly, 28, 438-453.

Marton, J. (2018). Min uppmaning till branschen är att tänka om [My call for the industry is to reconsider]. Tidningen Balans, (3), p. 38.

Maschi, T. (2016). Holistic Analysis, Discerning Meaning from Narrative and Numeric Data. In T. Maschi, Applying a Human Rights Approach to Social Work Research and Evaluation. SpringerBriefs in Rights-Based Approaches to Social Work. (pp. 69-81). Springer, Cham.

Mills, C. W. (1940). Situated actions and vocabularies of motive. American Sociological Review, 5(6): 904-913.

Moreland, R. L., Levine, J. M., \& McMinn, J. G. (2001/2012). Self-Categorization and Work Group Socialization. In Social Identity Processes in Organizational Contexts (pp. 87100). Binghamton, NY: The Haworth Press (Edition cited here is New York, NY: Psychology Press).

Muzio, D., \& Kirkpatrick, I. (2011). Introduction: Professions and organizations - a conceptual framework. Current Sociology, 59(4), 389-405.

Muzio, D., Brock, D. M., \& Suddaby, R. (2013). Professions and Institutional Change: Towards an Institutionalist Sociology of the Professions. Journal of Management Studies, 50(5), 699-721.

Ng, E. S., Schweitzer, L., \& Lyons, S. T. (2010). New Generation, Great Expectations: A Field Study of the Millennial Generation. Journal of Business and Psychology, 25(2), 281292.

Nolin, J. (2008). In search of a new theory of professions (Science for the professions Report no. 4). Borås: University of Borås.

Norris, D. R., \& Niebuhr, R. E. (1983). Professionalism, Organizational Commitment and Job Satisfaction in an Accounting Organization. Accounting, Organizations and Society, 9(1), 49--59.

O’Leary-Kelly, A. M., Henderson, K. E., Anand, V., \& Ashforth, B. E. (2014). Psychological Contracts in a Nontraditional Industry: Exploring the Implications for Psychological Contract Development. Group \& Organization Management, 39(3), 326-360.

Onwuegbuzie, A. J., \& Johnson, R. B. (2006). The Validity Issue in Mixed Research. Research in the Schools, 13(1), 48-63.

Picard, C.-F. (2016). The marketization of accountancy. Critical Perspectives on Accounting, 34, 79-97.

Power, M. (1997). The Audit Society: Rituals of Verification. Oxford: Oxford University Press.

Prop. 1981/82:171. Regeringens proposition 1981/82:171 om revisors kompetens m.m. [The Government's proposition 1981/82:171 on auditor competence et cetera]. Retrieved from Riksdagen.se: https://data.riksdagen.se/fil/6C20CA80-97AC-4F66-89569703BDB2A2AC

PwC. (2018). Arsredovisning 2017/2018 [Annual report 2017/2018]. Retrieved from PwC: https:/www.pwc.se/sv/om-oss/arsredovisning-2018-indexerad.pdf

Rahnert, K., \& Brunsson, K. (2019). Från kollega till konkurrent - ändrade attityder inom revisorskåren [From colleague to competitor - changed attitudes within the audit profession]. Organisation \& Samhälle, (2019(1)), pp. 58-63.

Raiborn, C., \& Stern, M. Z. (2019). The Need for New Psychological Contracts in the Auditing Profession. In C. Baker (Ed.), Research on Professional Responsibility and Ethics in Accounting (Research on Professional Responsibility and Ethics in Accounting, Vol. 
22) (pp. 81-98). Emerald Publishing Limited. Retrieved from https://doi.org/10.1108/S1574-076520190000022006

Ramirez, C. (2009). Constructing the governable small practitioner: The changing nature of professional bodies and the management of professional accountants' identities in the UK. Accounting, Organizations and Society, 34(3-4), 381-408.

Ramirez, C., Stringfellow, L., \& Maclean, M. (2015). Beyond segments in movement: a "small” agenda for research in the professions. Accounting, Auditing \& Accountability Journal, 28(8), 1341-1372.

Revisorsinspektionen. (2017). Revisorsinspektionens promemoria Den framtida revisionen: Morgondagens kompetenskrav - nya föreskrifter om utbildning och prov (Dnr 20171241) [The future audit: Tomorrows competence demands - new regulation on education and exam]. Retrieved 04 29, 2019, from Revisorsinspektionen: https://www.revisorsinspektionen.se/globalassets/webbplatsen/om-ri/framtidarevisionen/kompetenskrav/utbildningskrav-och-larandemal/pmrevisorsinspektionen.pdf

Revisorsinspektionen. (2019-a). Godkända och auktoriserade revisorer samt registrerade revisionsbolag 2019-04-01 [Approved and authorized auditors and registered audit companies 2019-04-01]. Retrieved from Revisorsinspektionen: https:/www.revisorsinspektionen.se/globalassets/webbplatsen/publicerat/manadsstatis tik/2019/revstat-2019-04.pdf

Revisorsinspektionen. (2019-b). Godkända och auktoriserade revisorer samt registrerade revisionsbolag 2019-05-03 [Approved and authorized auditors and registrated audit companies 2019-05-03]. Retrieved from Revisorsinspektionen: https://www.revisorsinspektionen.se/globalassets/webbplatsen/publicerat/manadsstatis tik/2019/revstat-2019-05.pdf

Revisorsinspektionen. (n.d. -a). Månadsstatistik [Monthly statistics]. Retrieved 04 29, 2019, from https://www.revisorsinspektionen.se/publikationer/manadsstatistik/

Revisorsinspektionen. (n.d. -b). Hur många revisionstimmar och branscher behöver jag för auktorisation/fortsatt auktorisation? [How many audit hours and industries do I need for authorization/continued authorization?). Retrieved 10 23, 2019, from Revisorsinspektionen: https:/www.revisorsinspektionen.se/vanliga-fragor-ochsvar/omauktorisation/hur-manga-revisionstimmar-behover-jag-for-att-bliauktoriserad-revisor-eller-for-att-erhalla-fortsatt-auktorisation-eller-godkannandesom/

Richardson, P., Dellaportas, S., Perera, L., \& Richardson, B. (2015). Towards a conceptual framework on the categorization of stereotypical perceptions in accounting. Journal of Accounting Literature, 35(1), 28-46.

RIFS 2018:1. Revisorsinspektionens föreskrifter (RIFS 2018:1) om revisorsexamen [Swedish Inspectorate of Auditors regulation (RIFS 2018:1) on auditor exam]. Stockholm: Per Johansson. Retrieved from Revisorsinspektionen: https:/www.revisorsinspektionen.se/globalassets/webbplatsen/regelverk/rifskonsoliderade-senaste-lydelsen/rifs-2018-1.pdf

Riksrevisionen. (2017). Avskaffandet av revisionsplikten för små aktiebolag - en reform som kostar mer än den smakar (DNR: 3.1.1-2016-0866) [The abolishment of the mandatory audit for small limited liability companies - a white elephant reform]. Retrieved from Riksdagen:

https://data.riksdagen.se/fil/52D3E20F-8C31-4EA5-B105-

67D55DD5FF52 
Rousseau, D. M. (1990). New Hire Perceptions of Their Own and Their Employer's Obligations: A Study of Psychological Contracts. Journal of Organizational Behavior, $11(5), 389-400$.

Saunders, M. N. (2012). Choosing research participants. In G. Symon, \& C. Cassell, Qualitative Organizational research (pp. 35-52). London: SAGE Publications Ltd.

Schalk, R., \& Roe, R. E. (2007). Towards a Dynamic Model of the Psychological Contract. Journal for the Theory of Social Behaviour, 37(2), 167-182.

Schudson, M. (1980). Reviewed Work: The Rise of Professionalism: A Sociological Analysis by Magali Sarfatti Larson. Theory and Society, 9(1), 215-229.

Scott, S. G., \& Lane, V. R. (2000). A Stakeholder Approach to Organizational Identity. Academy of Management Review, 25(1), 43-62.

Sekhar, C., Patwardhan, M., \& Singh, R. K. (2013). A literature review on motivation. Global Business Perspectives, 1(4), 471-487.

Sellers, R. D., \& Fogarty, T. J. (2010). The making of accountants: the continuing influence of early career experiences. Managerial Auditing Journal, 25(7), 710-719.

SFS 2001:883. Revisorslag [Auditor law]. Retrieved from https://www.riksdagen.se/sv/dokument-lagar/dokument/svenskforfattningssamling/revisorslag-2001883_sfs-2001-883

Siegel, P. H., Blank, M. M., \& Rigsby, J. T. (1991). Socialisation of the Accounting Professional: Evidence of the Effect of Educational Structure on Subsequent Auditor Retention and Advancement. Accounting, Auditing \& Accountability Journal, 4(4), 5870 .

Sillince, J. A., \& Brown, A. D. (2009). Multiple organizational identities and legitimacy: The rhetoric of police websites. Human Relations, 62(12), 1829-1856.

Smola, K. W., \& Sutton, C. D. (2002). Generational differences: Revisiting generational work values for the new millennium. Journal of Organizational Behaviour, 23(4), 363-382.

SOU 2008:32. Avskaffandet av revisionsplikten för små företag [Abolishment of mandatory audits for small companies]. Retrieved from https://www.regeringen.se/49bb8e/contentassets/053cd8567e8e4f9eb722ba734d0186c 8/avskaffande-av-revisionsplikten-for-sma-foretag-hela-dokumentet-sou-200832

Srf Konsulterna. (2017). Samverkan mellan Srf konsulterna och FAR avslutas [The collaboration between Srf konsulterna and FAR ends]. Retrieved 04 30, 2019, from MyNewsDesk:

https://www.mynewsdesk.com/se/srfkonsulterna/pressreleases/samverkan-mellan-srfkonsulterna-och-far-avslutas-2130292

Srf konsulterna. (n.d. -a). Varför du ska bli Auktoriserad Redovisningskonsult! [Why you should become an authorized accounting consultant!]. Retrieved 01 03, 2018, from Srf konsulterna: https://www.srfkonsult.se/studerande/redovisning/varfor-ark/

Srf konsulterna. (n.d. -b). Auktoriserade Lönekonsulter [Authorized pay roll consultants]. Retrieved 01 03, 2018, from Srf konsulterna: https://www.srfkonsult.se/omsrf/organisationen/auktoriserade-lonekonsulter/

Srf konsulterna. (n.d. -c). Om Srf konsulterna [About Srf konsulterna]. Retrieved 01 03, 2018, from Srf konsulterna: https://www.srfkonsult.se/om-srf/

Srf konsulterna. (n.d. -d). Antagningskrav [Admission requirements]. Retrieved 04 30, 2019, from Srf konsulterna: https:/www.srfkonsult.se/bli-auktoriserad/redovisning/hur-blirjag-auktoriserad/antagningskrav/

Steenackers, K., Breesch, D., \& Hardies, K. (2016). Auditors' length of stay in their first audit firm - An empirical study for the Belgian audit profession using survival analysis. Presented at the 6th Workshop on Audit Quality, Florence, Italy, 30th September 2016. 
Stenger, S., Garnier, C., \& Ramirez, C. (2017). The Audit Court Society: An Eliasian Framework for the Analysis of the Up-or-out System in PSFs. Academy of Management Proceedings, 2017(1). doi:https://doi.org/10.5465/ambpp.2017.15993abstract

Stets, J. E., \& Burke, P. J. (2000). Identity Theory and Social Identity Theory. Social Psychology Quarterly, 63(3), 224-237.

Stocks, M. H., \& Hardin, J. R. (2001). A comparison of job attitudes and turnover intentions among CPAs in public, private and governmental work settings. In Advances in Accounting Behavioral Research (Advances in Accounting Behavioral Research, Volume 4) (pp. 233-259). Emerald Group Publishing Limited.

Suddaby, R., Gendron, Y., \& Lam, H. (2009). The organizational context of professionalism in accounting. Accounting, Organizations and Society, 34(3-4), 409-427.

Svanberg, J., \& Öhman, P. (2013). Auditors' time pressure: does ethical culture support audit quality? Managerial Auditing Journal, 28(7), 572-591.

Svanberg, J., \& Öhman, P. (2015). Auditors' identification with their clients: Effects on audit quality. The British Accounting Review, 47(4), 395-408.

Sweeney, B., \& McGarry, C. (2011). Commercial and Professional Audit Goals: Inculcation of Audit Seniors. International Journal of Auditing, 15(3), 316-332.

Sylvander, J. (2018). Hur attraherar vi "rätt" personer till branschen? [How do we attract 'the right' people to the industry?]. Retrieved from Tidningen Balans: https://www.tidningenbalans.se/debatt/hur-attraherar-vi-ratt-personer-till-branschen/

Tajfel, H., \& Turner, J. C. (1979). An Integrative Theory of Intergroup Conflict. In W. G. Austin, \& S. Worchel, The Social Psychology of Intergroup Relations (pp. 33-47). Monterey, CA: Brooks/Cole.

Tajfel, H., \& Turner, J. C. (2004). The Social Identity Theory of Intergroup Behavior. In J. T. Jost, \& J. Sidanius (Eds.), Political Psychology: Key Readings (pp. 276-293). New York, NY: Psychology Press.

ten Bos, R. (1997). Essai: Business Ethics and Bauman Ethics. Organization Studies, 18(6), 997-1014.

Tienari, J., \& Vaara, E. (2016). Identity Construction in Mergers and Acquisitions: A discursive Sensemaking Perspective. In M. G. Pratt, M. Schultz, B. E. Ashforth, \& D. Ravasi (Eds.), The Oxford Handbook of Organizational Identity (pp. 455-473). Oxford: Oxford University Press.

Trank, C. Q., Rynes, S. L., \& Bretz Jr, R. D. (2002). Attracting applicants in the war for talent: Differences in work preferences among high achievers. Journal of Business and Psychology, 16(3), 331-345.

Turner, J. C., \& Reynolds, K. J. (2012). Self-Categorization Theory. In P. A. Van Lange, A. W. Kruglanski, \& E. T. Higgins (Eds.), Handbook of Theories of Social Psychology: Volume 2 (pp. 1-23). London: SAGE Publications Ltd. Retrieved from https://www.researchgate.net/publication/293162479_Self-categorization_theory

Twenge, J. M. (2010). A Review of the Empirical Evidence on Generational Differences in Work Attitudes. Journal of Business and Psychology, 25(2), 201-210.

Twenge, J. M., Campbell, S. M., Hoffman, B. J., \& Lance, C. E. (2010). Generational differences in work values: Leisure and extrinsic values increasing, social and intrinsic values decreasing. Journal of Management, 36(5): 1117-11142.

van Knippenberg, D. (2000). Work Motivation and Performance: A Social Identity Perspective. Applied Psychology: An International Review, 49(3), 357-371.

Van Maanen, J., \& Schein, E. H. (1979). Toward a theory of organizational socialization. In B. M. Staw (Ed.), Research in Organizational Behavior (Vol. 1, pp. 209-264). Greenwich, CT: JAI Press. 
Van de Ven, A. H. (2007). Engaged Scholarship: A guide for organizational and social research. Oxford: Oxford University Press.

von Nordenflycht, A. (2010). What is a professional service firm? Towards a theory and taxonomy of Knowledge intensive firms. Academy of Management Review, 35(1), 155174.

Wallerstedt, E. (2001). The emergence of the Big Five in Sweden. The European Accounting Review, 10(4), 843-867.

Warren, D. E., \& Alzola, M. (2009). Ensuring Independent Auditors: Increasing the Saliency of the Professional Identity. Group decision and negotiation, 18(1), 41-56.

Whetten, D. A. (2006). Albert and Whetten Revisited: Strengthening the Concept of Organizational Identity. Journal of Management Inquiry, 15(3), 219-234.

Whetten, D. A., \& Mackey, A. (2002). A Social Actor Conception of Organizational Identity and Its Implications for the Study of Organizational Reputation. Business \& Society, 41(4), 393-414.

Whittington, G. (2008). Fair Value and the IASB/FASB Conceptual Framework Project: An Alternative View. Abacus, 44(2), 139-168.

Wilden, R., Gudergan, S., \& Lings, I. (2010). Employer branding: strategic implications for staff recruitment. Journal of Marketing Management, 26(1-2), 56-73.

Wilensky, H. L. (1964). The Professionalization of Everyone? American Journal of Sociology, 70(2), 137-158.

Winter, R. P., \& Jackson, B. A. (2016). Work values preferences of Generation Y: performance relationship insights in the Australian Public Service. The International Journal of Human Resource Management, 27(17), 1997-2015.

Wisdom, J., \& Creswell, J. W. (2013). Mixed Methods: Integrating Quantitative and Qualitative Data Collection and Analysis While Studying Patient-Centered Medical Home Models [AHRQ Publication No. 13-0028-EF]. Retrieved from Agency for Healthcare Research and Quality: https://pcmh.ahrq.gov/sites/default/ files/attachments/MixedMethods_032513comp.pdf

Zeff, S. A. (1987). Does the CPA Belong to a Profession? Accounting Horizions, 1(June), 6568.

Öhman, P. (2007). Perspektiv på revision: tankemönster, förväntningsgap och dilemman [Perspectives on auditing: thought patterns, expectancy gaps and dilemmas]. Doctoral dissertation, Mid Sweden University, Department of Social Science.

Öhman, P., \& Wallerstedt, E. (2012). Audit regulation and the development of the auditing profession: The case of Sweden. Accounting History, 17(2), 241-257.

Öhman, P., Häckner, E., Jansson, A.-M., \& Tschudi, F. (2006). Swedish Auditors' View of Auditing: Doing Things Right versus Doing the Right Things. European Accounting Review, 15(1), 89-114. 
Appendix 1: Summary of appended papers 


\section{Paper I: Exploring potential (mis)matches between Millennials' wants and audit employment expectations and audit firm reality}

Researchers (e.g. George \& Wallio, 2017) and the Inspectorate of Swedish Auditors have raised the issue of retaining and attracting competent employees within the profession. As Millennials, the generation mainly recruited and currently employed within the audit profession, have a higher tendency to change jobs than previous generations, the paper argues for the need to better understand Millennials' professional wants and needs. Employment can be viewed as a psychological contract, where explicit and implicit promises are made by both employees and employers (Rousseau, 1990). The employment contract is initially anticipatory, and through employment experience the anticipatory expectations are either met or not. Unmet expectations have a negative influence on turnover intentions, job satisfaction and performance (e.g. O'Leary-Kelly et al, 2014). Millennials seem to be particularly sensitive to breaches of the anticipatory psychological employment contract, as they tend to switch jobs more frequently (cf. Laird et al., 2015; Ng et al., 2010), but in the audit context, met expectations have been shown to be positively correlated with actual decisions to leave the profession (Gertsson et al., 2017). Hence, there is a need to further explore how the psychological audit employment contract is perceived, especially by Millennials (cf. Herrbach, 2001). The aim of this paper is therefore to explore Millennials' professional wants and needs and audit employment expectations and to discuss potential (mis)matches with audit firm reality.

Prior studies have shown or argued that Millennials want frequent feedback from supervisors, need personal attention (e.g. Anderson et al., 2017), and value autonomy and work-life balance (Cennamo \& Gardner, 2008). Millennials are also claimed to be individualistic and self-centred (Twenge at al., 2010) and less altruistic than previous generations (Johnson \& Ng, 2016), but they are also claimed to value employers who are engaged in corporate social responsibility (Martin, 2005). Research has also shown that Millennials value the monetary aspects of work both more (e.g. Twenge, 2010) and less than previous generations (Hess \& Jepsen, 2009).

The analysis points to Millennials wanting and needing responsive employers, i.e. employers characterized by an open environment where needs and individuals are seen and taken care of. In other words, attractive employers from the Millennials' viewpoint are organizations that are influenced by and that adapt to their employees and where individuals are acknowledged for what they do, i.e. organizations with responsive management. Responsiveness as a concept comprises four subdimensions; personal development opportunities, fair compensation, worklife balance, and contribution opportunities. Millennials view personal development 
opportunities as growing and learning where you are. Development is also viewed as having varied work assignments, i.e. being stimulated, and having fun, and having colleagues that can help you. In other words, Millennials want horizontal rather than vertical development. Fair compensation means that you are paid appropriately for the work you do, fair in comparison to co-workers and your educational level and compensation that ensures security and being able to do the things you want. Work-life balance is not only related to not having a heavy workload, but also to flexibility in terms of when and where you work. Contribution opportunities are aspects that provide a sense of purpose and involve making a concrete unique contribution to the customer/client, employer and/or to society. The interviews pointed to contributing to the client as being a more concrete understanding of the societal benefits that the audit profession offers. In most aspects, the respondents were typical Millennials; however, only a few respondents strongly emphasized the importance of corporate social responsibility.

The anticipatory employment contract was perceived by Millennials as audit firms expecting them to 'know nothing', however, expecting them to work hard and learn, and be driven. Millennials thus expected that audit firms provide support and structure for them to learn the trade. The main inducement offered by audit firms was thus development, as heavy workload and low entry-level pay was expected by Millennials. However, Millennials also expected salaries to rise quickly and that anyone could climb the audit firm hierarchy.

The implications for the audit firms based on the findings and analysis can be summed up in one sentence: the 'up-or-out' incentive system is not appropriate for attracting and retaining Millennials. The 'up-or-out' system negatively affects the responsiveness of the organization, as it focuses on vertical development, creates 'unfair' compensation (cf. Lokatt, 2018; Stenger et al., 2017), influences who becomes a manager and seems to create unresponsive managers (cf. Donovan et al., 2016), and creates horizontal competition limiting individuals' incentives to help peers (Stenger et al., 2017). The analysis also points to issues with the education within the audit firms. As Millennials want a personal development that is tailored to their individual needs and wants, the audit firms' standardized education in the lower-level hierarchies may create job dissatisfaction (cf. Lokatt, 2018).

This study contributes with an understanding of what Millennials want from employers, and the key to attracting and retaining Millennials seems to be responsiveness, which as a concept it captures this generation's claimed sense of entitlement. This paper also highlights the practical implications for the audit firms and argues that major organizational changes are 
necessary in order to decrease the risks of a 'pyramid collapse', i.e. that not enough audit assistants become authorized auditors.

\section{Paper II: The audit profession as an 'divided' educational institution: perceptions of auditing among potential employees}

This paper explores the perceptions of the audit profession among potential employees. The audit profession is viewed as a social actor system, where the social actors range from the profession, to audit firms and individual auditors (cf. Ashforth et al., 2011; Whetten, 2006). All these actors interact and exchange information with their environment, which creates different perceptions of the profession among stakeholder groups (Scott \& Lane, 2000). In other words, the identity of the profession is cocreated by the social actors within the profession (cf. Brouard et al., 2017), and by its stakeholders as stakeholder perceptions influence the identity of the profession (Scott \& Lane, 2010; cf. Durocher, Bujaki, \& Brouard, 2016). The audit profession is becoming more and more fragmented as audit work is becoming more specialized (Carrington et al., 2019; Ramirez et al., 2015). Therefore, the profession may face challenges in portraying a coherent identity towards stakeholders, as the profession is represented by different actors with different motives and agendas, such as professional bodies, audit firms, and individual auditors. A less coherent identity may particularly influence the attraction of the profession among potential employees, as attraction is influenced by the clarity and credibility of the identity portrayed by the profession and the audit firms as employers (Wilden et al., 2010).

Professional associations and standard-setters focus on protecting professional jurisdiction by portraying an identity that highlights professional characteristics such as independence, abstract/unique knowledge, working in the public interest (Anderson-Gough et al., 1998; Brante, 1988) and strong shared ethics (Brien, 1998; Nolin, 2008), to ensure that stakeholders perceive auditing as legitimate (cf. Sillince \& Brown, 2009). In contrast, audit firms compete for the same strategical resources within the jurisdiction that they control, such as human resources, making it necessary for them to differentiate themselves from each other to ensure competitiveness (Ashforth et al., 2011; Whetten \& Mackey, 2002). Therefore, audit firms portray their organizational identities in different channels (Lievens \& Slaughter, 2016; Scott $\&$ Lane, 2000) in order to uphold a competitive advantage within the profession (cf. Barney, 1991, Whetten \& Mackey, 2002). Likewise, individual auditors portray themselves as auditors through their appearance and behaviour (e.g. Anderson-Gough et al., 1998; cf. Goffman, 1959), creating an unique individual identity within the constraints of both the professional and 
organizational identities to ensure their competitive advantage within the firm (cf. Stenger et al., 2017). These different agendas could result in discrepant messages being communicated to potential employees, thus influencing how they perceive the profession (cf. Wilden et al., 2010). In other words, the profession itself may be creating expectations gaps between potential employees' perceptions of the profession and audit profession reality, leading to the profession itself augmenting the problems of retaining competent staff within the profession (cf. e.g. Cable \& Judge, 1996).

This paper shows that potential employees perceive the audit profession as a profession who educates the future and current leaders of business society. The audit profession is thus, in the eyes of potential employees, a 'top-tier' educational institution that provides high-quality education, however with a tough study environment. The mission of the profession therefore seems to be to disseminate well educated 'alumni', rather than enabling well-functioning capital markets through the assurance of information between market parties.

The rhetoric of the profession, as perceived by potential employees depicts the clients as the kings (cf. Carter \& Spence, 2014). Potential and new employees' previous theoretical knowledge is not perceived as valuable as the profession communicates the messages that no entry requirements are necessary for entering the audit 'university', that students do not know anything, and that the profession will teach students the things they need to know. Students are expected to work and study efficiently and extensively, making drive and competitiveness essential professional traits. Failure to conform these high demands of the 'educational institution' have in research been shown to results in 'drop-outs' or expulsions (cf. Stenger et al., 2017). However, the students perceived it to be ok to 'dropout', and that you are welcome back to the profession when you gotten valuable experience elsewhere. These perceptions do not convey much new about the profession as these are aspects highlighted by previous studies (cf. e.g. Anderson-Gough et al., 1998; Bagley et al., 2012; Hanlon, 1996; Lokatt, 2018; Stenger et al., 2017). However, the extent to which potential employees view the audit profession as a higher education profession has not previously been highlighted in the literature.

The respondents perceived audit work differently depending on where the work was conducted. They perceived differences between working in a big or small office or in a big or small town, due to perceptions of auditors working with different clients in big versus small offices and towns. Hence, the paper indicates that differentiation within the profession does not occur on an organizational level, but rather at the office level and more importantly on the client level, 
as similarities and differences between firms and offices were related to the main type of clients the auditors serve. The main contribution of the study is the empirical finding that potential employees view the profession as a divided profession, where auditors are viewed as either small client auditors or large client auditors. This is a different dichotomized image of the profession in comparison to the Big 4/Non-Big 4 dichotomy, as it divides the profession based on the role the auditor serves for its clients rather than based on where the auditor works.

\section{Paper III: Exploring motivational drivers of audit employees - A study focusing on} Generation Y

This study ${ }^{58}$ argues that motivation is closely related to employee turnover and career change, and therefore it is important to further explore motivation among audit employees. This paper explores audit employees' perceptions of what motivates them and explains what factors influence audit employees' motivational drivers. The paper particularly focuses on what Millennials in the audit profession are motivated by.

Prior studies have shown that there are several motivational drivers that are likely to influence employee motivation and job satisfaction, such as organizational identity (Eskildsen et al., 2004), working conditions, and social aspects of work (Sekhar et al., 2013). Different generations are argued to be motivated by different aspect at work, as differences in work values have been shown to be explained to a higher degree by generational cohorts than maturity (Smola \& Sutton, 2002). Differences in what motivates audit employees are not only explained by generational differences. Research also indicates that gender (e.g. Herbohn, 2005), organizational culture (e.g. Herbohn, 2004; 2005), and the hierarchical position within the firm, tenure, and professional expertise (e.g. Bamber \& Iyer, 2009; Benke \& Rhode, 1980) influence motivation and job satisfaction. This paper identifies two new motivational drivers in the audit context, namely contributing to the client and the audit firm. Even though these aspects have been identified in the audit literature, they have not been directly related to motivation.

The results showed that motivational drivers in the audit context consist of five categorizes; intrinsic, social, material, status, and well-being drivers. The analysis points to the new motivational drivers contributing to the client and the audit firm being intrinsic drivers and

\footnotetext{
${ }^{58}$ In the published version of the paper, there are unfortunately some references missing in the reference list. These references are Baumeister (2016), Brown et al. (2016), Elliott \& Dweck (1988) and Svanberg \& Öhman (2015). There is also an error on p. $94 ; 65,6 \%$ of the respondents worked at a Non-Big4 firm, not a Big 4 firm as stated in the text.
} 
contributing to the client is the most important motivational driver among audit employees of all drivers (see table 2 in the appended paper). The least important motivational driver was competition, which may be problematic as the 'up-or-out' incentive system is based on competition. The results indicate that women and partners are more motivated by intrinsic drivers than men and audit assistants and that Millennials, women, and those working in bigger offices are more motivated by social drivers than other generations, men and those working in smaller offices. More experienced audit employees are also less motivated by social drivers than less experienced staff. Millennials and those working in bigger offices were more motivated by material drivers than other generations and those working in smaller offices, and both tenure and experiences decrease the motivation from material drivers. Millennials, those working in a larger office, auditors and partners were more motivated by status drivers in comparison to other generations, those working in smaller offices and audit assistants. Women were motivated more by well-being drivers than men.

The study contributes an understanding of what Millennial audit employees are motivated by and gives some indications of how motivation changes with experience gained. The results do not indicate that motivation differs between Big 4 and Non-Big 4 firm staff; however, motivation differs depending on the size of the office the employee works in, which indicates that large and small offices attract and retain different types of individuals (cf. Bagley et al., 2012; Causholli et al., 2019).

\section{Paper IV: Exploring audit assistants' decision to leave the audit profession}

This paper addresses the issue of high employee turnover among lower-level staff in the audit profession. Even though a certain level of natural turnover is necessary, as it increases organizational efficiency by for example stimulating innovation (Dalton \& Todor, 1979), excessive turnover may result in 'brain drains' as highly competent individuals have a higher propensity to leave organizations (Abbasi \& Hollman, 2000). For the audit profession, being a professional service industry where knowledgeable individuals are the main resource (von Nordenflycht, 2010), a high turnover of lower-level staff may result in detrimental long-term effects if not enough audit assistants take and pass their authorization exam and stay within the profession (cf. appended paper I).

The study explores the association between determinants of job satisfaction and audit assistants' actual decision to leave the audit profession by surveying both current and former audit assistants. Job satisfaction is argued as an important determinant of turnover, and the paper 
identifies three broad categories of job satisfaction determinants; 1) perceptions of the profession, 2) work conditions, and 3) work environment. As the study explores the relations between determinants of job satisfaction and actual turnover, rather than the more commonly used outcome turnover intentions not representing actual decisions, the contribution is an empirical investigation of how these determinants influence actual choices. The study also identified perceptions of the profession as an aspect influencing turnover not previously used in empirical studies that examine how job satisfaction influences an exit from a profession. As audit firms can be viewed as hybrid-identity firms, i.e. having both a public interest and commercial purpose (e.g. Broberg, 2013), how individuals perceive the profession can influence job satisfaction and turnover (cf. Schalk \& Roe, 2007).

The results showed that work-life balance (one of two subfactors of work conditions) and perceptions of the profession had a negative association with the choice to quit the profession. In other words, those who experience low work-life balance and those who perceive the profession as not being professional (i.e. as less prestigious, meaningful, intellectually stimulating, and providing societal benefits and career development to a lesser degree) seem to exit the profession to a greater extent than those experiencing work-life balance and the work as professional. The results also pointed to increased flexibility decreasing the probability of an exit. In contrast to theory, the results also indicated that a low expectation gap increased the probability to exit the profession. This means that those who got what they expected had a greater propensity to exit the profession. The work environment did not show a significant association with the decision to leave the profession, indicating that social relationships, organizational pride and perceived justice in pay and promotion are not aspects predicting turnover in the Swedish audit context.

This study contributes to the literature on employee turnover in audit firms and particularly regarding how determinants of job satisfaction influence the actual choice to leave the profession. The study also highlights the importance of perceptions of the profession as a determinant of career change. 


\section{Part II: Appended Papers}




\section{Papers}

The papers associated with this thesis have been removed for copyright reasons. For more details about these see:

http://urn.kb.se/resolve?urn=urn:nbn:se:liu:diva-164026 



\section{FACULTY OF ARTS AND SCIENCES}

Linköping Studies in Arts and Sciences No. 784, 2020

Department of Management and Engineering

Linköping University

SE-581 83 Linköping, Sweden

www.liu.se 